\title{
2020 taxonomic update for phylum Negarnaviricota (Riboviria: Orthornavirae), including the large orders Bunyavirales
}

\section{and Mononegavirales}

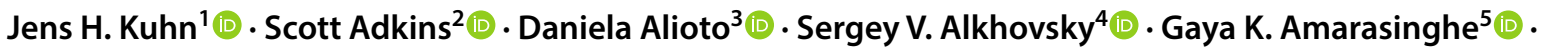
Simon J. Anthony ${ }^{6,7} \cdot$ Tatjana Avšič-Županc $^{8}$ - María A. Ayllón ${ }^{9,10}$. Justin Bahl ${ }^{11}$ (1) . Anne Balkema-Buschmann ${ }^{12}$ - Matthew J. Ballinger ${ }^{13}$ (1) . Tomáš Bartonička ${ }^{14}(1) \cdot$ Christopher Basler $^{15}(1)$.

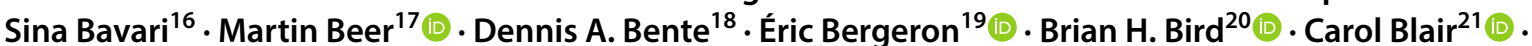
Kim R. Blasdell ${ }^{22}$. Steven B. Bradfute ${ }^{23}$ (1) Rachel Breyta ${ }^{24}$. Thomas Briese ${ }^{25}$ (D) Paul A. Brown ${ }^{26}(1) \cdot$ Ursula J. Buchholz ${ }^{27}$. Michael J. Buchmeier ${ }^{28}$ (D) Alexander Bukreyev ${ }^{18,29}$ (D) Felicity Burt $^{30}$ (D) Nihal Buzkan ${ }^{31}$ (D)

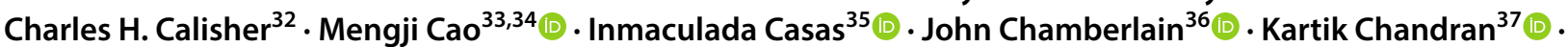
Rémi N. Charrel ${ }^{38}$ - Biao Chen ${ }^{39} \cdot$ Michela Chiumenti $^{40}$ (1) Il-Ryong Choi ${ }^{41} \cdot$ J. Christopher S. Clegg ${ }^{42}$.

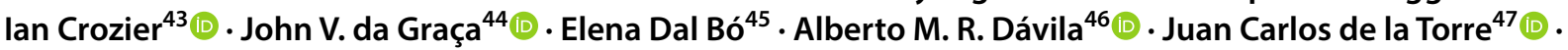

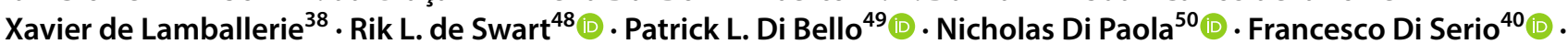
Ralf G. Dietzgen ${ }^{51}$ - Michele Digiaro ${ }^{52} \cdot$ Valerian V. Dolja $^{53}$ (1) Olga Dolnik ${ }^{54}$ (1) Michael A. Drebot ${ }^{55}$. Jan Felix Drexler ${ }^{56}$ - Ralf Dürrwald ${ }^{57}$ (D) Lucie Dufkova ${ }^{58}$. William G. Dundon ${ }^{59}$ (D) W. Paul Duprex ${ }^{60}$.

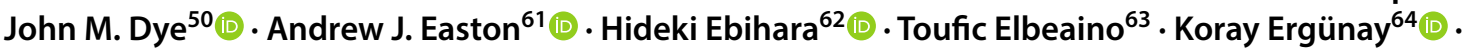
Jorlan Fernandes ${ }^{195}$ (D) . Anthony R. Fooks ${ }^{65}$ (D) Pierre B. H. Formenty ${ }^{66}$ (D) Leonie F. Forth ${ }^{17}$ (D) Ron A. M. Fouchier ${ }^{48}$ (1) . Juliana Freitas-Astúa ${ }^{67}$ (1) Selma Gago-Zachert ${ }^{68,69}$ (1) $\cdot$ George Fú Gāo $^{70}$. María Laura García ${ }^{71}$. Adolfo García-Sastre ${ }^{72}$ - Aura R. Garrison ${ }^{50}$ (1) Aiah Gbakima ${ }^{73}$ - Tracey Goldstein $^{74}$ (1) . Jean-Paul J. Gonzalez ${ }^{75,76}$ - Anthony Griffiths ${ }^{77}$ (1) - Martin H. Groschup ${ }^{12}$ (D) - Stephan Günther ${ }^{78}$ (1)

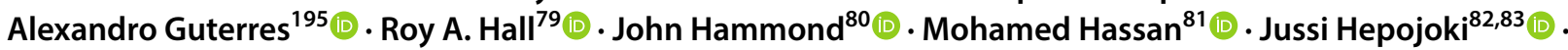

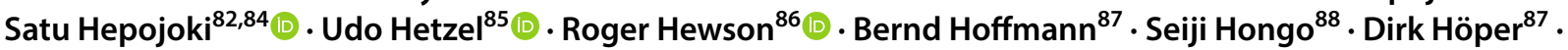

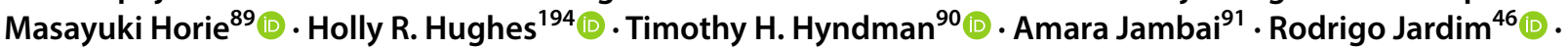
Dàohóng Jiāng ${ }^{92}$ (D) Qi Jin ${ }^{93,94}$. Gilda B. Jonson ${ }^{95}$. Sandra Junglen ${ }^{56,118}$. Serpil Karadağ ${ }^{96}$ • Karen E. Keller ${ }^{97}$.

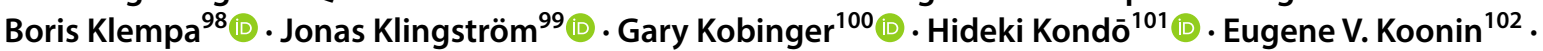

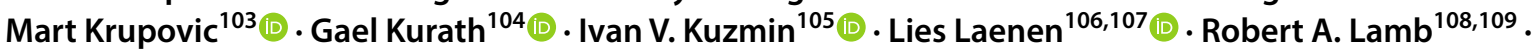

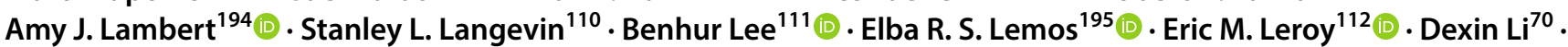

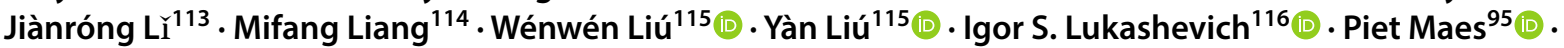
William Marciel de Souza ${ }^{117}$ (D) Marco Marklewitz ${ }^{56,118}$ (D) Sergio H. Marshall ${ }^{119}$. Giovanni P. Martelli ${ }^{120}$. Robert R. Martin ${ }^{121}$. Shin-Yi L. Marzano ${ }^{122}$. Sébastien Massart ${ }^{123}$. John W. McCauley ${ }^{124}$ () . Nicole Mielke-Ehret ${ }^{125}$. Angelantonio Minafra ${ }^{40}$ - Maria Minutolo ${ }^{3}$ (1) $\cdot$ Ali Mirazimi $^{126} \cdot$ Hans-Peter Mühlbach $^{125}$.

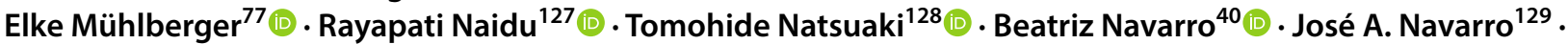

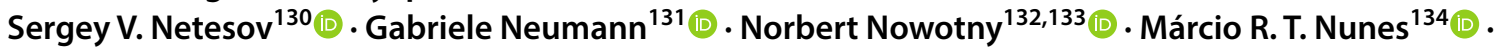

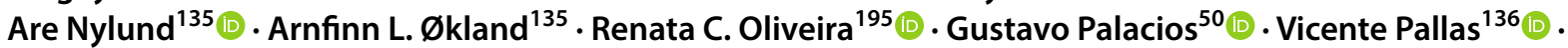
Bernadett Pályi ${ }^{137}$ (1) Anna Papa ${ }^{138}$. Colin R. Parrish ${ }^{139}$. Alex Pauvolid-Corrêa ${ }^{140}$ - Janusz T. Pawęska ${ }^{141}$ (1) .

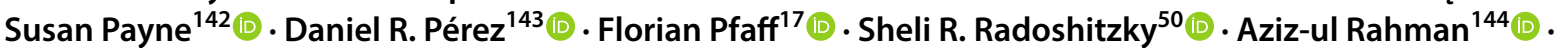
Pedro L. Ramos-González ${ }^{145}$ (1) . Renato O. Resende ${ }^{146}$ (D) . Carina A. Reyes ${ }^{147} \cdot$ Bertus K. Rima $^{148}$ (1) . Víctor Romanowski ${ }^{149}$. Gabriel Robles Luna ${ }^{147}$. Paul Rota ${ }^{150}$. Dennis Rubbenstroth ${ }^{17}$. Jonathan A. Runstadler ${ }^{151}$ (1) .

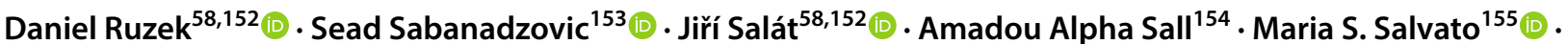
Kamil Sarpkaya ${ }^{156} \cdot$ Takahide Sasaya $^{157}$ (i) - Martin Schwemmle ${ }^{158}$ (D) Muhammad Z. Shabbir ${ }^{144}$ (D)

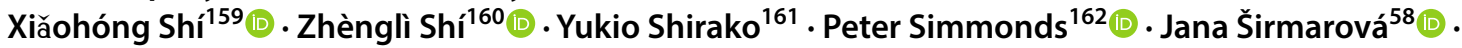

Handling Editor: Tim Skern and Sead Sabanadzovic.

Giovanni P. Martelli: Deceased.

Extended author information available on the last page of the article 
Manuela Sironi $^{163}$ (D) Sophie Smither ${ }^{164} \cdot$ Teemu Smura $^{82}$ (D) Jin-Won Song ${ }^{165} \cdot$ Kirsten M. Spann $^{166}$ (D) Jessica R. Spengler ${ }^{19}$ (D) Mark D. Stenglein ${ }^{167}$ (D) . David M. Stone ${ }^{168}$ (D) Petra Straková ${ }^{58}$ (D) Ayato Takada ${ }^{169}$ (D) . Robert B. Tesh ${ }^{29} \cdot$ Natalie J. Thornburg ${ }^{170} \cdot$ Keizō Tomonaga $^{171}$ (D) . Noël Tordo ${ }^{172,173}$ (D) Jonathan S. Towner ${ }^{19}$. Massimo Turina $^{174}$ (D) Ioannis Tzanetakis ${ }^{175}$ (D) . Rainer G. Ulrich ${ }^{176,177}$ (D) . Anna Maria Vaira ${ }^{178}$ (D) .

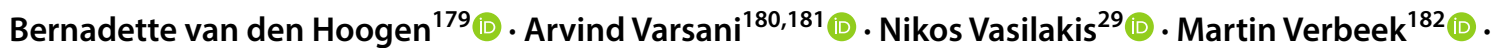
Victoria Wahl $^{183}$ (D) Peter J. Walker ${ }^{196}$ (D) Hui Wang ${ }^{115} \cdot$ Jianwei Wang $^{184}$ (D) Xifeng Wang ${ }^{115}$ (D) $\cdot$ Lin-Fa Wang $^{185}$ (D)

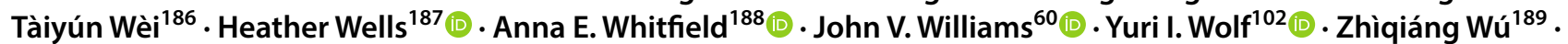
Xin Yang $^{39} \cdot$ Xīnglóu Yáng ${ }^{160}$ (D) Xuejie Yu ${ }^{190}$ (D) Natalya Yutin ${ }^{102}$ (D) . F. Murilo Zerbini ${ }^{191}$ (D) Tong Zhang ${ }^{39}$. Yong-Zhen Zhang ${ }^{192,193} \cdot$ Guohui Zhou $^{39} \cdot$ Xueping Zhou ${ }^{115}$

Received: 15 June 2020 / Accepted: 4 July 2020 / Published online: 4 September 2020

(C) This is a U.S. Government work and not under copyright protection in the US; foreign copyright protection may apply 2020

\begin{abstract}
In March 2020, following the annual International Committee on Taxonomy of Viruses (ICTV) ratification vote on newly proposed taxa, the phylum Negarnaviricota was amended and emended. At the genus rank, 20 new genera were added, two were deleted, one was moved, and three were renamed. At the species rank, 160 species were added, four were deleted, ten were moved and renamed, and 30 species were renamed. This article presents the updated taxonomy of Negarnaviricota as now accepted by the ICTV.
\end{abstract}

\section{Introduction}

Phylum Negarnaviricota was established in 2019 by the International Committee on Taxonomy of Viruses (ICTV) for negative-sense RNA viruses that can be connected evolutionarily through their encoded RNA-directed RNA polymerase (RdRp) core domains. The phylum includes two subphyla, Haploviricotina and Polyploviricotina, for negative-sense RNA viruses that encode large (L) proteins with or without mRNA capping activity, respectively. The two subphyla include four classes (Chunqiuviricetes, Milneviricetes, Monjiviricetes, and Yunchangviricetes) and two classes (Ellioviricetes and Insthoviricetes), respectively $[56,109,136]$. The vast majority of viruses that have been assigned to phylum Negarnaviricota belong to two orders: Mononegavirales (established in 1991 [92] and amended/ emended in 1995 [16], 1997 [93], 2000 [94], 2005 [95], 2011 [32], 2016 [2], 2017 [7], March 2018 [8], October 2018 [66], and 2019 [9]) and Bunyavirales (established in 2017 and amended/emended in 2018 [64, 65] and 2019 [1]).

Here we present the changes that were proposed to the entire phylum Negarnaviricota via official ICTV taxonomic proposals (TaxoProps) in 2019 and that were accepted by the ICTV in March 2020 [128]. These changes are now part of the official ICTV taxonomy.

\section{Taxonomic changes above the phylum rank}

Until recently, Negarnaviricota, included in realm Riboviria (established in 2019 [127]), was the only established phylum in the ICTV framework. In 2020, virus taxonomy was amended to include Negarnaviricota in the new riboviriad kingdom Orthornavirae as one of five sister phyla [55] (TaxoProp 2019.006G.A.v1.Riboviria).

\section{Taxonomic changes at the subphylum rank}

No new subphyla were created.

\section{Taxonomic changes at the class rank}

No new classes were created.

\section{Taxonomic changes at the order rank}

No new orders were created. 


\section{Taxonomic changes within order Goujianvirales (Haploviricotina: Yunchangviricetes)}

No changes were made.

\section{Taxonomic changes within order Jingchuvirales (Haploviricotina: Monjiviricetes)}

\section{Family Chuviridae}

One new species, Taiyuan mivirus, was added to genus Mivirus for Tàiyuán leafhopper virus (TYLeV) first discovered by high-throughput sequencing (HTS) in a leafhopper (Psammotettix alienus (Dahlbom, 1850)) sampled in Tàiyuán (太原), Shānxī Province (山西省), China [129] (TaxoProp 2019.018M.A.v2.1newsp_Taiyuan_mivirus).

\section{Taxonomic changes within order Mononegavirales (Haploviricotina: Monjiviricetes)}

\section{Family Artoviridae}

The family was expanded by one new genus, Hexartovirus, including one new species, Caligid hexartovirus, for Lepeophtheirus salmonis negative-stranded RNA virus 1 (LsNSRV-1) first discovered by HTS in salmon lice (Lepeophtheirus salmonis (Krøyer, 1837)) sampled on the west coast of Norway [81]. Species Barnacle peropuvirus was moved from genus Peropuvirus into genus Hexartovirus and renamed Barnacle hexartovirus (TaxoProp 2019.021M.A.v1.1newgenus_Hexartovirus).

\section{Family Bornaviridae}

No changes were made.

\section{Family Filoviridae}

The family was expanded by one genus, Dianlovirus, including a single new species, Mengla dianlovirus, for Měnglà virus (MLAV) discovered by HTS in a Rousettus sp. bat sampled in Měnglà County (㖵腊县), Yúnnán Province ( 云南省), China [145, 146] (TaxoProp 2019.011M.A.v1. Mengla_dianlovirus).

One new species, Bombali ebolavirus, was created in genus Ebolavirus, for Bombali virus (BOMV) first discovered by consensus PCR and confirmed by HTS in little free-tailed bats (Chaerephon pumilus (Cretzschmar, 1830-1831)) and Angolan free-tailed bats (Mops condylurus (A. Smith, 1833)) sampled in Bombali District, Northern Province, Sierra Leone [37] (TaxoProp 2019.007M.A.v2. Bombali_ebolavirus).

\section{Family Lispiviridae}

No changes were made.

\section{Family Mymonaviridae}

A new genus, Hubramonavirus, was established for two new species: Hubei hubramonavirus for Húběi rhabdo-like virus 4 (HbRLV-4) discovered by HTS in an arthropod mix collected in Húběi Province (湖北省), China [106] and Lentinula hubramonavirus for Lentinula edodes negativestrand RNA virus 1 (LeNSRV-1) first detected by HTS in commercial shiitakes (Lentinula edodes (Berk.) Pegler (1976)) sampled in Japan [60] (TaxoProp 2019.001F.A.v1. Hubramonavirus_1gen).

\section{Family Nyamiviridae}

No changes were made.

\section{Family Paramyxoviridae}

The overlooked deletion of species Bat mumps orthorubulavirus and the overlooked renaming of species Synodus paramyxovirus to Synodus synodonvirus were corrected (TaxoProp 2019.016M.A.v1.Corrections).

The family was expanded by three new genera: genus Cynoglossusvirus for the already established species Cynoglossus paramyxovirus (now renamed Cynoglossus cynoglossusvirus); genus Hoplichthysvirus for the already established species Hoplichthys paramyxovirus (now renamed Hoplichthys hoplichthysvirus); and genus Scoliodonvirus for the already established species Scoliodon paramyxovirus (now renamed Scoliodon scoliodonvirus) (TaxoProp 2019.025M.A.v2.Paramyxoviridae_3gen5sp4rensp).

Genus Aquaparamyxovirus was expanded by one species, Oncorhynchus aquaparamyxovirus, for Pacific salmon paramyxovirus (PSPV) first isolated from Chinook salmon (Oncorhynchus tshawytscha (Walbaum, 1792)) in Oregon, USA [135]. Species Salmon aquaparamyxovirus was renamed Salmo aquaparamyxovirus (TaxoProp 2019.025M.A.v2.Paramyxoviridae_3gen5sp4rensp).

Genus Jeilongvirus was expanded by one species, Miniopteran jeilongvirus, for "bat paramyxovirus isolate BatParaV/B16-40" (here renamed Shaan virus [ShaV]) first isolated from a Schreibers's long-fingered bat (Miniopterus schreibersii (Kuhl, 1817)) feces sampled in Danyang County (단 양 군), North Chungcheong Province (충 청북도), South Korea [79] (TaxoProp 2019.025M.A.v2.Paramyxoviridae_ 3gen5sp4rensp).

Genus Orthoavulavirus was expanded erroneously by two species, Avian orthoavulavirus 21 and Avian orthovulavirus 21 [sic], for the same virus, "avian paramyxovirus 17" (here 
renamed avian paramyxovirus 21 [APMV-21]) first isolated from bird feces collected in Seosan (서산 시), South Chungcheong Province (충 청 남 도), South Korea [48] (TaxoProps 2019.014M.A.v1.Avulavirus_1newsp and 2019.025M.A.v2. Paramyxoviridae_3gen5sp4rensp).

Genus Orthorubulavirus was expanded by one species, Mammalian orthorubulavirus 6, for Alston virus (AlsV) first isolated from pteropodid bat urine sampled in Alstonville, New South Wales, Australia [49] (TaxoProp 2019.025M.A.v2.Paramyxoviridae_3gen5sp4rensp).

Genus Pararubulavirus was expanded by one species, Hervey pararubulavirus, for Hervey virus (HerV) first isolated from pteropodid bat urine sampled in Hervey Bay, Queensland, Australia [11, 53]. (TaxoProp 2019.025M.A.v2. Paramyxoviridae_3gen5sp4rensp).

Genus Respirovirus was expanded by one species, Squirrel respirovirus, for giant squirrel virus (GSqV) first isolated from a Sri Lankan giant squirrel (Ratufa macroura (Pennant, 1769)) sampled in a German zoo [35] (TaxoProp 2019.019M.A.v2.1newsp_Squirrel_respirovirus).

\section{Family Rhabdoviridae}

Genus Almendravirus was expanded by one species, Menghai almendravirus, for Menghai rhabdovirus (MRV) first isolated from Asian tiger mosquitoes (Aedes albopictus (Skuse, 1894)) collected in Měnghăi County (勐海县) in Yúnnán Province (云南省), China [113] (TaxoProp 2019.033M.N.v1.Menghai_almendravirus_1sp).

Genus Nucleorhabdovirus was split into three genera, Alphanucleorhabdovirus, Betanucleorhabdovirus, and Gammanucleorhabdovirus (TaxoProp 2019.031M.Ac.v1.Nucleorhabdovirus_splitgen). Established species Eggplant mottled dwarf nucleorhabdovirus, Maize Iranian mosaic nucleorhabdovirus, Maize mosaic nucleorhabdovirus, Potato yellow dwarf nucleorhabdovirus, Rice yellow stunt nucleorhabdovirus, and Taro vein chlorosis nucleorhabdovirus were assigned to genus Alphanucleorhabdovirus and renamed Eggplant mottled dwarf alphanucleorhabdovirus, Maize Iranian mosaic alphanucleorhabdovirus, Maize mosaic alphanucleorhabdovirus, Potato yellow dwarf alphanucleorhabdovirus, Rice yellow stunt alphanucleorhabdovirus, and Taro vein chlorosis alphanucleorhabdovirus, respectively. Established species Datura yellow vein nucleorhabdovirus, Sonchus yellow net nucleorhabdovirus, and Sowthistle yellow vein nucleorhabdovirus were assigned to genus Betanucleorhabdovirus and renamed Datura yellow vein betanucleorhabdovirus, Sonchus yellow net betanucleorhabdovirus, and Sowthistle yellow vein betanucleorhabdovirus, respectively. Established species Maize fine streak nucleorhabdovirus was assigned to genus Gammanucleorhabdovirus and renamed Maize fine streak gammanucleorhabdovirus (TaxoProp 2019.031M.Ac.v1. Nucleorhabdovirus_splitgen).
Three new species were established in genus Alphanucleorhabdovirus:

- Morogoro maize-associated alphanucleorhabdovirus for Morogoro maize-associated virus (MMaV) first detected by HTS in maize (Zea mays L.) sampled in Morogoro, Morogoro Region, Tanzania [97];

- Physostegia chlorotic mottle alphanucleorhabdovirus for Physostegia chlorotic mottle virus (PhCMoV) first isolated from lionhearts (Physostegia sp.) in Austria [76]; and

- Wheat yellow striate alphanucleorhabdovirus for wheat yellow striate virus (WYSV) first isolated from common wheat (Triticum aestivum L.) sampled in Hánchéng (韩 城), Shănxī/Shaanxi Province (陕西省), China [61] (TaxoProp 2019.031M.Ac.v1.Nucleorhabdovirus_splitgen).

Three new species were established in genus Betanucleorhabdovirus:

- Alfalfa betanucleorhabdovirus for alfalfa-associated nucleorhabdovirus (AaNV) first discovered by HTS in alfalfa (Medicago sativa L.) sampled in Stadl-Paura, Upper Austria (Oberösterreich), Austria [36];

- Blackcurrant betanucleorhabdovirus for blackcurrantassociated rhabdovirus (BCaRV) first discovered by HTS in blackcurrant (Ribes nigrum L.) sampled in Russia [138]; and

- Trefoil betanucleorhabdovirus for birds-foot trefoilassociated virus (BFTV) first discovered by HTS in Bird's-foot trefoil (Lotus corniculatus L.) sampled in the Qínlǐng Mountains (秦岭山), Shănxī/Shaanxi Province ( 陕西省), China [26, 131] (TaxoProp 2019.031M.Ac.v1. Nucleorhabdovirus_splitgen).

One new genus, Arurhavirus, was established to include four species:

- Aruac arurhavirus for Aruac virus (ARUV) first isolated from mosquitoes (Trichoprosopon theobaldi Lane and Cerqueira, 1942) collected in Melaju Forest, Trinidad, Trinidad and Tobago [110, 126];

- Inhangapi arurhavirus for Inhangapi virus (INHV) first isolated from sandflies (Lutzomyia flaviscutellata (Mangabeira, 1942)) collected in Catu Forest, Belém, Pará State, Brazil [3, 126];

- Santabarbara arurhavirus for Santa Barbara virus (SBAV) first in mice sampled in Santa Bárbara do Pará, Pará State, Brazil [unpublished]; and

- Xiburema arurhavirus for Xiburema virus (XIBV) first isolated from mosquitoes (Sabethes intermedius (Lutz, 1904)) sampled in Sena Madureira, Acre State, Brazil [51, 132] (2019.006M.A.v1.Arurhavirus_1gen4sp). 
One new genus, Barhavirus, was established to include two new species:

- Bahia barhavirus for Bahia Grande virus (BGV) first isolated from mosquitoes (Aedes, Culex, Anopheles, Psorophora spp.) collected in Texas, Louisiana, New Mexico, and North Dakota, USA [52, 126] and also for Harlingen virus (HARV) isolated from salt marsh mosquitoes (Culex salinarius Coquillett, 1904) sampled in Harlingen, Texas, USA [126].

- Muir barhavirus for Muir Springs virus (MSV) first isolated from mosquitoes (Aedes sp.) collected in Fort Morgan, Colorado, USA [52, 126] (TaxoProp 2019.012M.A.v1.Rhabdoviridae_5gen8sp1reasp).

One new genus, Lostrhavirus, was established to include new species Lonestar zarhavirus [sic] for lone star tick rhabdovirus (LSTRV) first detected by HTS in lone star ticks (Amblyomma americanum (Linnaeus, 1758)) collected in the USA [unpublished] (TaxoProp 2019.012M.A.v1. Rhabdoviridae_5gen8sp1reasp).

One new genus, Mousrhavirus, was established to include the previously established species Moussa virus (now renamed Moussa mousrhavirus) (TaxoProp 2019.012M.A.v1.Rhabdoviridae_5gen8sp1reasp).

One new genus, Ohlsrhavirus, was established to include five new species:

- Culex ohlsrhavirus for Culex rhabdo-like virus (CRLV) first discovered by HTS in southern house mosquitoes (Culex quinquefasciatus Say, 1823) collected near Perth, Western Australia, Australia [107];

- Northcreek ohlsrhavirus for North Creek virus (NORCV) first discovered by HTS in mosquitoes (Culex sitiens Wiedemann, 1828) collected in Ballina, New South Wales, Australia [23];

- Ohlsdorf ohlsrhavirus for Ohlsdorf virus (OHLDV) first discovered by HTS in mosquitoes (Ochlerotatus cantans (Meigen, 1818)) collected in Hamburg, Germany [105];

- Riverside ohlsrhavirus for riverside virus (RISV) first discovered by HTS in mosquitoes (Ochlerotatus sp.) collected in Gemenc, Gyékényes, and Drávaszabolcs, Hungary [98]; and

- Tongilchon ohlsrhavirus for Tongilchon virus 1 (TCHV1) first detected in mosquitoes (Culex bitaeniorhynchus Giles, 1901) collected in Tongil-chon (통 일 촌), Gyeonggi Province (경기도), South Korea [39] (TaxoProp 2019.032M.N.v1.Ohlsrhavirus_1gen5sp).
One new genus, Sawgrhavirus, was established to include four new species:

- Connecticut sawgrhavirus for Connecticut virus (CNTV) first isolated from ticks (Ixodes dentatus Marx, 1899) taken from an eastern cottontail (Sylvilagus floridanus (J. A. Allen, 1890)) captured in Lyme, Connecticut, USA $[67,126]$;

- Island sawgrhavirus for Long Island tick rhabdovirus (LITRV) first detected by HTS in lone star ticks (Amblyomma americanum (Linnaeus, 1758)) collected on Long Island, New York, USA [119];

- Minto sawgrhavirus for New Minto virus (NMV) first isolated from rabbit ticks (Haemaphysalis leporispalustris Packard, 1869) sampled in New Minto, Alaska, USA [99, 126]; and

- Sawgrass sawgrhavirus for Sawgrass virus (SAWV) isolated from American dog ticks (Dermacentor variabilis (Say, 1821)) sampled at Sawgrass Lake, Tampa Bay, Florida, USA [102, 126] (TaxoProp 2019.012M.A.v1. Rhabdoviridae_5gen8sp1reasp).

One new genus, Sunrhavirus, was established to accommodate six novel species:

- Garba sunrhavirus for Garba virus (GARV) first isolated from a malachite kingfisher (Corythornis cristatus (Pallas, 1764)) trapped in Bangui, Central African Republic $[51,126]$;

- Harrison sunrhavirus for Harrison Dam virus (HARDV) first isolated from common banded mosquitoes (Culex annulirostris Skuse, 1889) collected at Beatrice Hill, Northern Territory, Australia [71];

- Kwatta sunrhavirus for Kwatta virus (KWAV) first isolated from mosquitoes (Culex sp.) collected near Paramaribo, Suriname [25, 126];

- Oakvale sunrhavirus for Oak Vale virus (OVV) first isolated from mosquitoes (Culex edwardsi Barraud, 1923) sampled in Peachester, Queensland, Australia [77, 96];

- Sunguru sunrhavirus for Sunguru virus (SUNV) first isolated from a domestic chicken (Gallus gallus domesticus (Linnaeus, 1758)) in Arua District, Northern Region, Uganda [58]; and

- Walkabout sunrhavirus for Walkabout Creek virus (WACV) first isolated from biting midges (Culicoides austropalpalis Lee and Reye, 1955) collected near Samford, Queensland, Australia [71] (2019.004M.A.v2.Sunrhavirus). 
One new genus, Zarhavirus, was created for one new species, Zahedan zarhavirus, for Zahedan rhabdovirus (ZARV) first isolated from ticks (Hyalomma anatolicum anatolicum (Koch, 1844)) collected in Zâhedân (زاهدان), Sistan and Baluchestan Province (استان سـيستان و بلوحستان), Iran [28] (TaxoProp 2019.012M.A.v1.Rhabdoviridae_5gen8sp1reasp).

One new species, Taiwan bat lyssavirus, was added to genus Lyssavirus for Taiwan bat lyssavirus (TWBLV) first isolated from a Japanese pipistrelle (Pipistrellus abramus (Temminck, 1838)) sampled in Taiwan [45] (TaxoProp 2019.001M.A.v1.Lyssavirus).

Genus Cytorhabdovirus was expanded by 12 species:

- Cabbage cytorhabdovirus for cabbage cytorhabdovirus 1 (CCyV-1) first discovered by HTS in cabbage (Brassica oleracea L.) sampled in the UK [89];

- Maize-associated cytorhabdovirus for maize-associated cytorhabdovirus (MaCV) first discovered by HTS in maize (Zea mays L.) collected in Lima, Peru [133];

- Maize yellow striate cytorhabdovirus for maize yellow striate virus (MYSV) first discovered by HTS in maize (Zea mays L.) and common wheat (Triticum aestivum L.) collected in Sinsacate, Córdoba Province, Argentina [70];

- Papaya cytorhabdovirus for papaya virus E (PpVE) first discovered by HTS in papaya (Carica papaya L.) sampled in Los Ríos Province, Ecuador [73];

- Persimmon cytorhabdovirus for persimmon virus A (PeVA) first discovered by HTS in Japanese persimmon (Diospyros kaki L.f.) sampled in Japan [47];

- Raspberry vein chlorosis cytorhabdovirus for raspberry vein chlorosis virus (RVCV) first discovered by HTS in red raspberries (Rubus idaeus L.) sampled in Dundee, Scotland, UK [50];

- Rice stripe mosaic cytorhabdovirus for rice stripe mosaic virus (RSMV) first discovered by HTS in rice (Oryza sativa L.) sampled in Luódìng (罗定), Guăngdōng Province (广东省), China [147];

- Tomato yellow mottle-associated cytorhabdovirus for tomato yellow mottle-associated virus (TYMaV) first discovered by HTS in tomato (Solanum lycopersicum L.) sampled in Chóngqìng (重庆), China [141];

- Wuhan 4 insect cytorhabdovirus for Wuhan insect virus 4 (WuIV-4) first discovered by HTS in mealy plum aphids (Hyalopterus pruni (Geoffroy, 1762)) sampled in Wǔhàn (武汉), Húběi Province (湖北省), China [59];

- Wuhan 5 insect cytorhabdovirus for Wuhan insect virus 5 (WuIV-5) first discovered by HTS in mealy plum aphids (Hyalopterus pruni (Geoffroy, 1762)) sampled in Wǔhàn (武汉), Húběi Province (湖北省), China [59];

- Wuhan 6 insect cytorhabdovirus for Wuhan insect virus 6 (WuIV-6) first discovered by HTS in mealy plum aphids (Hyalopterus pruni (Geoffroy, 1762)) sampled in Wǔhàn (武汉), Húběi Province (湖北省), China [59]; and
- Yerba mate chlorosis-associated cytorhabdovirus for yerba mate chlorosis-associated virus (YmCaV) [12] first discovered by HTS in yerba mate (Ilex paraguariensis A. St.-Hil.) sampled in Cerro Azul, Misiones Province, Argentina (TaxoProps 2019.002M.A.v3.Cytorhabdovirus and 2019.030M.A.v1.Cytorhabovirus_12newsp).

One new species, Holmes hapavirus, was added to genus Hapavirus for Holmes Jungle virus (HOJV) first isolated from common banded mosquitoes (Culex annulirostris Skuse, 1889) collected near Darwin, Northern Territory, Australia [38] (2019.003M.A.v3.Hapavirus).

Three new species were added to genus Sripuvirus:

- Charleville sripuvirus for Charleville virus (CHVV) first isolated from sandflies (Phlebotomus sp.) collected in Charleville, Queensland, Australia [29, 123];

- Cuiaba sripuvirus for Cuiaba virus (CUIV) isolated from a cane toad (Rhinella marina (Linnaeus, 1758)) captured in Pará State, Brazil [51, 123]; and

- Hainan sripuvirus for Hainan black-spectacled toad rhabdovirus (HnBSTRV) first detected by HTS in an Asian common toad (Duttaphrynus melanostictus (Schneider, 1799)) sampled in Hăinán Province (海南省), China [108] (TaxoProp 2019.013M.A.v1.Sripuvirus_3newsp).

\section{Taxonomic changes within order Muvirales (Haploviricotina: Chunqiuviricetes)}

No changes were made.

\section{Taxonomic changes within order Serpentovirales (Haploviricotina: Milneviricetes)}

No changes were made.

\section{Taxonomic changes within order Articulavirales (Polyploviricotina: Insthoviricetes)}

No changes were made.

\section{Taxonomic changes within order Bunyavirales (Polyploviricotina: Ellioviricetes)}

\section{Family Arenaviridae}

Genus Hartmanivirus was expanded by three species: Muikkunen hartmanivirus for Dante Muikkunen virus 1 (DaMV1), Schoolhouse hartmanivirus for old schoolhouse viruses 1 and 2 (OScV-1/2), and Zurich hartmanivirus for veterinary pathology Zurich viruses 1 and 2 (VPZV-1/2), all first detected by HTS in captive boid snakes [44] (TaxoProp 2019.008M.A.v2.Hartmanivirus_3new sp). 
Genus Mammarenavirus was expanded by four species:

- Alxa mammarenavirus for RtDs-AreV/IM2014 virus (here renamed Alxa virus [ALXV]) (TaxoProp 2019.020M.A.v2.1newsp_Alxa_mammarenavirus) first discovered by HTS in a Northern three-toed jerboa (Dipus sagitta (Pallas, 1773)) sampled in Alxa Left Banner (阿拉善左旗), Inner Mongolia Autonomous Region (内蒙古自治区), China [139, 140];

- Chevrier mammarenavirus for Lìjiāng virus (LIJV) first discovered by HTS in a Chevrier's field mouse (Apodemus chevrieri (Milne-Edwards, 1868)) sampled around Lìjiāng (丽江), Yúnnán Province (云南省), China [unpublished] (TaxoProp 2019.009M.A.v2.Mammarenavirus_sp_LIJV);

- Planalto mammarenavirus for Aporé virus (APOV) first discovered by HTS in a Mato Grosso colilargo (Oligoryzomys mattogrossae (J. A. Allen, 1916)) sampled in Cassilândia, Mato Grosso do Sul State, Brazil (TaxoProp 2019.010M.A.v1.Mammarenavirus_sp_APOV) [34]; and

- Xapuri mammarenavirus for Xapuri virus (XAPV) first discovered by HTS in a Musser's neacomys (Neacomys musseri Patton, da Silva, and Malcolm, 2000) sampled in Xapuri, Acre State, Brazil [33] (TaxoProp 2019.005M.A.v1.Mammarenavirus_sp_XAPV).

\section{Family Fimoviridae}

Genus Emaravirus was expanded by two species: Blackberry leaf mottle associated emaravirus for blackberry leaf mottle-associated virus (BLMaV) first discovered in blackberries (Rubus spp.) collected in various US states (TaxoProp 2019.010P.A.v1.Emaravirus_1sp) [41] and Pistacia emaravirus $B$ for pistacia virus B (PiVB) discovered by HTS in pistachios (Pistacia vera L.) sampled in Turkey [18] (TaxoProp 2019.011P.A.v1.Emaravirus_1sp).

\section{Family Hantaviridae}

Genus Loanvirus was expanded by one species, Brno loanvirus, for Brno virus (BRNV) first discovered by HTS in a noctule (Nyctalus noctula (Schreber, 1774)) sampled in Brno, South Moravia Region (Jihomoravský kraj), Czech Republic [112] (TaxoProp 2019.017M.A.v3.1newsp_Brno_virus).

\section{Family Peribunyaviridae}

Genus Pacuvirus was expanded by two species: new species Caimito pacuvirus for Caimito virus (CAIV) first isolated from sandflies (Nyssomyia ylephiletor (Fairchild and Hertig, 1952)) sampled in El Aguacate, Panamá Province, Panama [46, 116] (TaxoProp 2019.022M.A.v2.2sp_Pacuvirus) and Chilibre pacuvirus (the former Chilibre phlebovirus, renamed and moved from genus Phlebovirus) (TaxoProps 2019.022M.A.v2.2sp_Pacuvirus and 2019.026M.A.v1. Phenuiviridae_4gen79sp).

\section{Family Phasmaviridae}

The previously established genus Inshuvirus and its included species Insect inshuvirus were both abolished due to insufficient member virus information (TaxoProp 2019.028M.A.v2.Phasmaviridae_1newsp_abollgen3sp).

New species Anopheles orthophasmavirus was included in genus Orthophasmavirus for Anopheles triannulatus orthophasmavirus (AtOPV) first discovered by HTS in mosquitoes (Anopheles triannulatus (Neiva and Pinto, 1922)) sampled in Santa Bárbara Farm, Amapá State, Brazil [103]. Two species, Nome phantom orthophasmavirus and Seattle orthophasmavirus, were abolished (TaxoProp 2019.028M.A.v2. Phasmaviridae_1newsp_abol1gen3sp).

\section{Family Phenuiviridae}

The previously unassigned genus Coguvirus was included in family Phenuiviridae (TaxoProp 2019.026M.A.v1. Phenuiviridae_4gen79sp). One new species, Coguvirus eburi, was created in the genus for citrus virus A (CiVA) first discovered by HTS in a sweet orange tree in Italy [78] (2019.004P.A.v1.Coguvirus_1sp).

Genus Banyangvirus and included species Huaiyangshan banyangvirus, Guertu banyangvirus, and Heartland banyangvirus were renamed Bandavirus, Dabie bandavirus, Guertu bandavirus, and Heartland bandavirus, respectively (TaxoProps 2019.015M.A.v1.Bandavirus and 2019.026M.A.v1.Phenuiviridae_4gen79sp). Four new bandavirus species were added to the genus:

- Bhanja bandavirus for Bhanja virus (BHAV) first isolated from flat-inner-spurred haemaphysalids (Haemaphysalis intermedia Warburton and Nuttall, 1909) sampled in Orissa State, India [27, 104];

- Hunter Island bandavirus for Hunter Island virus (HUIV) first isolated from ticks (Ixodes eudyptidis Maskell, 1885) sampled on Albatross Island, Tasmania, Australia [130];

- Kismaayo bandavirus for Kismaayo virus (KISV; name corrected from the previously circulating "Kismayo virus" and "Kisemayo virus") first isolated from yellow back ticks (Rhipicephalus pulchellus (Gerstäcker, 1873)) sampled in Kismaayo, Lower Juba (Jubbada Hoose) Region, Somalia [149]; and

- Lone Star bandavirus [sic] for lone star virus (LSV) first isolated from lone star ticks (Amblyomma americanum (Linnaeus, 1758)) sampled in Kentucky, USA [54, 114] (TaxoProp 2019.026M.A.v1.Phenuiviridae_4gen79sp). 
Genus Entovirus was created for one new species, Entoleuca entovirus, for Entoleuca phenui-like virus 1 (EnPLV1) first discovered by HTS in Entoleuca sp. fungi sampled in Málaga Province, Spain [124] (TaxoProp 2019.026M.A.v1. Phenuiviridae_4gen79sp).

Genus Kabutovirus and included species Kabuto mountain kabutovirus and Huangpi kabutovirus were renamed Uukuvirus, Kabuto mountain uukuvirus, and Huangpi uukuvirus, respectively. The established species Uukuniemi phlebovirus was moved into genus Uukuvirus and renamed Uukuniemi uukuvirus. 14 new species were established in genus Uukuvirus:

- American dog uukuvirus for American dog tick virus (ADAV) first detected by HTS in American dog ticks (Dermacentor variabilis (Say, 1821)) sampled in Heckscher State Park, New York, USA [120];

- Dabieshan uukuvirus for Dàbiéshān tick virus (DbsTV) first discovered by HTS in Asian longhorned ticks (Haemaphysalis longicornis Neumann, 1901) collected in the Dàbié Mountains (大別山), China [59];

- Grand Arbaud uukuvirus for Grand Arbaud virus (GAV) first isolated from ticks (Argas reflexus (Fabricius, 1794)) sampled in Bouches-du-Rhône Department, France [40, 85];

- Kaisodi uukuvirus for Kaisodi virus (KASDV) first isolated from hard-bodied ticks (Haemaphysalis spinigera Neumann, 1897) sampled in Mysore State, India [14, 88, 144];

- Lihan uukuvirus for Lìhán tick virus (LITV) first discovered by HTS in Asian blue ticks (Rhipicephalus microplus (Canestrini, 1888)) sampled in Lǐhán (李韩), Húběi Province (湖北省), China [59];

- Murre uukuvirus for murre virus (MURV) first isolated from common murres (Uria aalge (Pontoppidan, 1763)) sampled in Alaska, USA [85];

- Pacific coast uukuvirus for Pacific coast tick virus (PACTV) first discovered by HTS in Pacific coast ticks (Dermacentor occidentalis Marx, 1892) sampled in Mendocino County, California, USA [17];

- Precarious Point uukuvirus for Precarious Point virus (PPV) first isolated from seabird ticks (Ixodes uriae White, 1852) sampled on Macquarie Island, Tasmania, Australia [85, 111];
- Rukutama uukuvirus for Rukutama virus (RUKV) first isolated from seabird ticks (Ixodes uriae White, 1852) sampled on Tûlenij/Tyuleny Island (Остров Тюлений), Sakhalin Oblast (Сахалинская область), Russia [63, 150];

- Schmidt uukuvirus for EgAn 1825-61 virus (here renamed Nile warbler virus [NIWV]) first isolated from a willow warbler (Phylloscopus trochilus (Linnaeus, 1758)) sampled in Nile Delta, Egypt [85];

- Silverwater uukuvirus for Silverwater virus (SILV) first isolated from rabbit ticks (Haemaphysalis leporispalustris Packard, 1869) sampled near Powassan, Ontario, Canada [69, 72];

- Tacheng uukuvirus for Tăchéng tick virus 2 (TcTV-2) first discovered by HTS in ticks (Dermacentor marginatus Sulzer, 1776) sampled in China [59];

- Yongjia uukuvirus for Yǒngjiā tick virus 1 (YjTV-1) first discovered by HTS in East Asian mountain haemaphysalids (Haemaphysalis hystricis Supino, 1897) in China [59]; and

- Zaliv Terpeniya uukuvirus for Zaliv Terpeniya virus (ZTV) first isolated from seabird ticks (Ixodes uriae White, 1852) sampled on Tyuleny Island (Тюлений остров) in the Gulf of Patience (Залив Терпения), Sakhalin Oblast (Сахалинская область) and Commander Islands (Командорские острова), Kamchatka Krai (Камчатский край), RSFSR, USSR [62, 151] (TaxoProp 2019.026M.A.v1.Phenuiviridae_4gen79sp).

Genus Ixovirus was established for the three new species:

- Blackleg ixovirus for blacklegged tick phlebovirus 1, here renamed blacklegged tick virus 1 (BLTV-1), first discovered by HTS in deer ticks (Ixodes scapularis Say, 1821) sampled in Heckscher State Park, New York, USA [120];

- Norway ixovirus for Norway phlebovirus 1, here renamed Fairhair virus (FHAV), first discovered by HTS in castor bean ticks (Ixodes ricinus (Linnaeus, 1758)) sampled in Norway [91]; and

- Scapularis ixovirus for blacklegged tick phlebovirus 3 , here renamed blacklegged tick virus 3 (BLTV-3), first discovered by HTS in deer ticks (Ixodes scapularis Say, 1821) sampled in Heckscher State Park, New York, USA [120] (TaxoProp 2019.026M.A.v1. Phenuiviridae_4gen79sp). 
Genus Lentinuvirus was created for one new species, Lentinula lentinuvirus, for Lentinula edodes negativestrand RNA virus 2 (LeNSRV-2) first discovered by HTS in shiitakes (Lentinula edodes (Berk.) Pegler (1976)) sampled in Japan [60] (TaxoProp 2019.026M.A.v1. Phenuiviridae_4gen79sp).

In genus Phlebovirus, established species Sandfly fever Naples phlebovirus was renamed Naples phlebovirus. The genus was expanded by 53 new species (TaxoProp 2019.026M.A.v1.Phenuiviridae_4gen79sp):

- Adana phlebovirus for Adana virus (ADAV) first isolated from Phlebotomus spp. sandflies sampled in Adana, Adana Province (Adana ili), Turkey [4];

- Aguacate phlebovirus for Aguacate virus (AGUV) first isolated from Lutzomyia spp. sandflies sampled in El Aguacate, Panamá Province, Panama [82, 116];

- Alcube phlebovirus for Alcube virus (ACBV) first isolated from sandflies (Phlebotomus perniciosus Newstead, 1911) sampled around Arrábida, Portugal [10];

- Alenquer phlebovirus for Alenquer virus (ALEV) first isolated from a human in Ramal das Pias, Alenquer, Pará State, Brazil [83, 122];

- Ambe phlebovirus for Ambe virus (ABEV) first isolated from psychodid sandflies sampled near Altamira, Pará State, Brazil [80, 118];

- Anhanga phlebovirus for Anhangá virus (ANHV) first isolated from a Linnaeus's two-toed sloth (Choloepus didactylus (Linnaeus, 1758)) sampled in Castanhal Forest, Pará State, Brazil [80];

- Arumowot phlebovirus for Arumowot virus (AMTV) first isolated from mosquitoes (Culex antennatus (Becker, 1903)) sampled in Sudan [13, 84];

- Buenaventura phlebovirus for Buenaventura virus (BUEV) first isolated in 1984 from Lutzomyia sp. sandflies sampled in Rio Raposo, Valle del Cauca Department, Colombia [87, 116];

- Cacao phlebovirus for Cacao virus (CACV) first isolated from sandflies (Nyssomyia trapidoi (Fairchild and Hertig, 1952)) sampled in El Aguacate, Panamá Province, Panama [87, 116];

- Campana phlebovirus for Campana virus (CMAV) first isolated from phlebotomine sandflies sampled in El Aguacate, Panamá Province, Panama [87];

- Chagres phlebovirus for Chagres virus (CHGV) first isolated from a human sampled at Fort Sherman, Canal Zone/Cólon Province, Panama [90];
- Cocle phlebovirus for Coclé virus (CCLV) first isolated from a human sampled in Penonomé, Coclé Province, Panama [87];

- Dashli phlebovirus for Dāshlī virus (DASV) first isolated from Sergentomyia sp. sandflies sampled in Dāshlīborun (داشلىبرون), Golestān Province (استان كلستان), Iran [6];

- Durania phlebovirus for Durania virus (DRNV) first isolated from sandflies sampled in 1986 near Durania, North Santander Department, Colombia [82, 118];

- Echarate phlebovirus for Echarate virus (ECHV) first isolated from a human sampled in Cusco, Peru [83];

- Gabek phlebovirus for Gabek Forest virus (GFV) first isolated from a northeast African spiny mouse (Acomys cahirinus (É. Geoffroy, 1803)) sampled in Gabek Forest, near Paloich, Sudan [86];

- Gordil phlebovirus for Gordil virus (GORV) first isolated from a typical lemniscomys (Lemniscomys striatus (Linnaeus, 1758)) sampled in Gordil, Vakaga Prefecture, Central African Republic [86];

- Icoaraci phlebovirus for Icoaraci virus (ICOV) first isolated from from an unidentified forest rat sampled in Belém, Pará State, Brazil [19, 142];

- Itaituba phlebovirus for Itaituba virus (ITAV) first isolated from a common opossum (Didelphis marsupialis Linnaeus, 1758) trapped at the Tapacurazinho stream, Itaituba, Pará State, Brazil [83, 122];

- Itaporanga phlebovirus for Itaporanga virus (ITPV) first isolated from a sentinel Swiss mouse collected in Itaporanga, São Paulo State, Brazil [46, 121];

- Ixcanal phlebovirus for Ixcanal virus (IXCV) first isolated from Lutzomyia sp. sandflies sampled in Aldea Ixcanal and Aldea Puerta, El Progreso Departmesp. sandflies innt, Guatemala [82, 118];

- Karimabad phlebovirus for Karimabad virus (KARV) first isolated from Phlebotomus sp. sandflies in Karīmābād (كريخ اباد), Khūzestān Province (استان خوزستان), Iran [86];

- La Gloria phlebovirus for La Gloria virus (LAGV) first discovered by HTS in phlebotomine sandflies sampled near La Gloria village, Panama Canal area, central Panama [68];

- Lara phlebovirus for GGP-2011a virus (here renamed Rio Claro virus [RICV]) first isolated from a sentinel hamster sampled in Venezuela [unpublished];

- Leticia phlebovirus for Leticia virus (LETV) first isolated from sandflies sampled in Leticia, Amazonas Department, Colombia [87]; 
- Maldonado phlebovirus for Maldonado virus (MLOV) first isolated from a human sampled in Puerto Maldonado, Madre de Dios Region, Peru [83];

- Massilia phlebovirus for Massilia virus (MASV) first isolated from sandflies (Phlebotomus perniciosus Newstead, 1911) sampled in Marseille and Nice, Provence-AlpesCôte d'Azur, France [20, 86];

- Medjerda phlebovirus for Medjerda Valley virus (MVV) first isolated from phlebotomine sandflies sampled at an archaeological site in Bizerte Governorate, Tunisia [15];

- Mona Grita phlebovirus for Mona Grita virus (MOGV) first discovered by HTS in sandflies (Nyssomyia trapidoi (Fairchild and Hertig, 1952)) sampled on Isla Mona Grita, Panama Canal, central Panama [68];

- Munguba phlebovirus for Munguba virus (MUNV) first isolated from sandflies (Nyssomyia umbratilis (Ward and Fraiha, 1977)) sampled in Monte Dourado, Pará State, Brazil [80, 122];

- Nique phlebovirus for Nique virus (NIQV) first isolated from sandflies (Lutzomyia panamensis (Shannon, 1926)) sampled in Cerro Nique, Darién Province, Panama [83, 117];

- Ntepes phlebovirus for Ntepes virus (NTPV) first isolated from Sergentomyia sp. sandflies sampled near Ntepes village, Marigat District, Baringo County, Kenya [115];

- Odrenisrou phlebovirus for Odrénisrou virus (ODRV) first isolated from mosquitoes (Culex albiventris Edwards, 1922) collected in the forest of Taï National Park, Côte d'Ivoire [84];

- Oriximina phlebovirus for Oriximiná virus (ORXV) first isolated from Lutzomyia sp. sandflies sampled in Saracazinho, Pará State, Brazil [83, 122];

- Pena Blanca phlebovirus for Peña Blanca virus (PEBV) first discovered by HTS in sandflies sampled on Peña Blanca peninsula, Panama Canal, central Panama [68];

- Punique phlebovirus for Punique virus (PUNV) first isolated from sandflies (Phlebotomus perniciosus Newstead, 1911 and Phlebotomus longicuspis Nitzulescu, 1930) sampled in Tunis, Tunisia [86];

- Rio Grande phlebovirus for Rio Grande virus (RGV) first isolated from a Southern Plains woodrat (Neotoma micropus Baird, 1855) sampled in Texas, USA [46];

- Saint Floris phlebovirus for Saint-Floris virus (SAFV) first isolated from a gerbil sampled in Gordil, Vakaga Prefecture, Central African Republic [86];
- Salanga phlebovirus for Salanga virus (SLGV) first isolated from a Hinde's aethomys (Aethomys hindei (Thomas, 1902)) collected in Salanga, Ombella-M'Poko Prefecture, Central African Republic [51, 148];

- Salobo phlabovirus [sic] for Salobo virus (SLBOV) first isolated from a Guyenne spiny-rat (Proechimys guyannensis (E. Geoffroy, 1803)) in Pará State, Brazil [142];

- Sicilian phlebovirus for sandfly fever Sicilian virus (SFSV) first isolated from a human sampled in Palermo Province, Sicily Region, Italy [101, 137];

- Tapara phlebovirus for Tapará virus (TPRV) first isolated from phlebotomine sandflies in Altamira, Pará State, Brazil [80];

- Tehran phlebovirus for Tehran virus (THEV) first isolated from sandflies (Phlebotomus papatasi (Scopoli, 1786)) sampled in Tehran, Iran [86];

- Tico phebovirus [sic] for Tico virus (TICV) discovered by HTS in sandflies sampled in Panama Canal area, central Panama [68];

- Toros phlebovirus for Toros virus (TORV) first discovered by HTS in sandflies sampled in Damyeri, Adana Province (Adana ili), Turkey [5];

- Toscana phlebovirus for Toscana virus (TOSV) first isolated from sandflies (Phlebotomus perniciosus Newstead, 1911) in Toscany, Italy [86, 125];

- Tres Almendras phlebovirus for Tres Almendras virus (TRAV) first discovered by HTS in sandflies (Psychodopygus panamensis (Shannon, 1926)) sampled on Tres Almendras Islands, Panama Canal area, central Panama [68];

- Turuna phlebovirus for Turuna virus (TUAV) first isolated from Lutzomyia sp. sandflies sampled in Cachoeira Porteira, Pará State, Brazil [83, 122];

- Uriurana phlebovirus for Uriurana virus (URIV) first isolated from phlebotomine sandflies in Tucuruí, Pará State, Brazil [80];

- Urucuri phlebovirus for Urucuri virus (URUV) first isolated from a Guyenne spiny-rat (Proechimys guyannensis (E. Geoffroy, 1803)) in Utinga Forest, Belém, Pará State, Brazil [80, 122];

- Viola phlebovirus for viola virus (VIOV) first discovered by HTS in sandflies (Lutzomyia longipalpis (Lutz and Neiva, 1912)) sampled in Pirizal, Mato Grosso State, Brazil [24]; and 
- Zerdali phlebovirus for Zerdali virus (ZERV) first discovered by HTS in sandflies sampled in Zerdali, Adana Province (Adana ili), Turkey [5].

Genus Rubodvirus was created for the two new species Apple rubodvirus 1 and 2 to accommodate apple rubbery wood viruses 1 and 2 (ARWV-1/2), respectively, first discovered using HTS in apple trees (Malus sp.) sampled in Germany and USA [100] (TaxoProp 2019.026M.A.v1. Phenuiviridae_4gen79sp).

One new species, Melon tenuivirus, was added to genus Tenuivirus for melon chlorotic spot virus (MeCSV) first isolated from muskmelon (Cucumis melo L.) sampled in Provence-Alpes-Côte d'Azur Region, France [57].

Genus Wubeivirus was abolished and its two species, Fly wubeivirus and Dipteran wubeivirus, were moved into genus Phasivirus and renamed Fly phasivirus and Dipteran phasivirus, respectively (TaxoProp 2019.026M.A.v1. Phenuiviridae_4gen79sp).

\section{Family Tospoviridae}

The overlooked adjustment of 12 tospovirid species names to correct non-Latinized binomials was implemented (TaxoProp 2019.016M.A.v1.Corrections).

Eight new species were created in genus Orthotospovirus:

- Alstroemeria necrotic streak orthotospovirus for Alstroemeria necrotic streak virus (ANSV) first isolated from ornamental crops (Alstroemeria sp.) sampled in Colombia [42];

- Alstroemeria yellow spot orthotospovirus for Alstroemeria yellow spot virus (AYSV) first isolated from ornamental crops (Alstroemeria sp.) imported to and sampled in the Netherlands [43];
- Groundnut chlorotic fan spot orthotospovirus for groundnut chlorotic fan-spot virus (GCFSV) first isolated from peanut (Arachis hypogaea L.) sampled in Taiwan [21];

- Hippeastrum chlorotic ringspot orthotospovirus for Hippeastrum chlorotic spot virus (HCRV) first isolated from amaryllis (Hippeastrum sp.) and spider lily (Hymenocallis littoralis (Jacq.) Salisb.) sampled in southwestern China [31, 143];

- Mulberry vein banding associated orthotospovirus for mulberry vein banding-associated virus (MVBaV) discovered first by HTS in mulberry (Morus alba L.) sampled in Guăngxī Zhuàng Autonomous Region (广西壮 族自治区), China in 2011 [74, 75];

- Pepper chlorotic spot orthotospovirus for pepper chlorotic spot virus (PCSV) first isolated from sweet pepper (Capsicum annuum L.) in Taiwan [22];

- Tomato yellow ring orthotospovirus for tomato yellow ring virus (TYRV) first isolated from tomato (Solanum lycopersicum L.) in Iran [134]; and

- Tomato zonate spot orthotospovirus for tomato zonate spot virus (TZSV) first isolated from tomato (Solanum lycopersicum L.) and chili pepper (Capsicum annuиm L.) sampled in Yúnnán Province (云南省), China [30] (TaxoProp 2019.006P.A.v1.Orthotospovirus_8sp).

\section{SUMMARY}

A summary of the current, ICTV-accepted taxonomy of the phylum Negarnaviricota is presented in Table 1 (Goujianvirales), Table 2 (Jingchuvirales), Table 3 (Mononegavirales), Table 4 (Muvirales), Table 5 (Serpentovirales), Table 6 (Articulavirales), and Table 7 (Bunyavirales).

Table 1 ICTV-accepted taxonomy of the order Goujianvirales (Negarnaviricota: Haploviricotina: Yunchangviricetes) as of March 2020

\begin{tabular}{lll}
\hline Genus & Species $^{\text {II }}$ & Virus (Abbreviation) ${ }^{\&}$ \\
\hline Family Yueviridae & & \\
Yuyuevirus & Beihai yuyuevirus* & Běihǎi sesarmid crab virus 3 (BhSCV-3) \\
& Shahe yuyuevirus & Shāhé yuèvirus-like virus 1 (ShYLV-1) \\
\hline
\end{tabular}

Note that viruses are real objects that are assigned to concepts that are called taxa. Species, genera, families, and orders are taxa

*Type species

ITaxon names are always italicized and always begin with a capital letter

${ }^{\&}$ Virus names are not italicized and are not capitalized, except if the name or a name component is a proper noun. This column lists the virus names with their correct (lack of) capitalization. Lists of viruses within a given species are provisional at this point and will likely be amended in the near future 
Table 2 ICTV-accepted taxonomy of the order Jingchuvirales (Negarnaviricota: Haploviricotina: Monjiviricetes) as of March 2020

\begin{tabular}{|c|c|c|}
\hline Genus & Species $^{\text {II }}$ & Virus (Abbreviation) ${ }^{\&}$ \\
\hline \multicolumn{3}{|c|}{ Family Chuviridae } \\
\hline \multirow[t]{31}{*}{ Mivirus } & Argas mivirus & Tăchéng tick virus 4 (TcTV-4) \\
\hline & Barnacle mivirus* & Běihăi barnacle virus 9 (BhBV-9) \\
\hline & Beetle mivirus & Húběi coleoptera virus 3 (HbCV-3) \\
\hline & Bole mivirus & Bólè tick virus 3 (BTV-3) \\
\hline & Brunnich mivirus & Wēnlǐng crustacean virus 14 (WlCV-14) \\
\hline & Changping mivirus & Chāngpíng tick virus 2 (CpTV-2) \\
\hline & Charybdis mivirus & Wēnzhōu crab virus 3 (WzCV-3) \\
\hline & Cockroach mivirus & Wǔchāng cockroach virus 3 (WcLFV-3) \\
\hline & Crab mivirus & Wēnzhōu crab virus 2 (WzCV-2) \\
\hline & Crustacean mivirus & Wēnlǐng crustacean virus 13 (WlCV-13) \\
\hline & Dermacentor mivirus & Chāngpíng tick virus 3 (CpTV-3) \\
\hline & & Tăchéng tick virus 5 (TcTV-5) \\
\hline & Hermit mivirus & Běihăi hermit crab virus 3 (BhHCV-3) \\
\hline & Hippoboscid mivirus & Wǔhàn louse fly virus 7 (WhLFV-7) \\
\hline & Hubei mivirus & Húběi chǔvirus-like virus 1 (HbCLV-1) \\
\hline & Hubei odonate mivirus & Húběi chǔvirus-like virus 3 (HbCLV-3) \\
\hline & Imjin mivirus & Imjin River virus 1 (IjRV-1) \\
\hline & Lacewing mivirus & Shuāngào insect virus 5 (SgIV-5) \\
\hline & Lishi mivirus & Líshí spider virus 1 (LsSV-1) \\
\hline & Lonestar mivirus & lone star tick chǔvirus 1 (LSTCV-1) \\
\hline & Louse fly mivirus & Wǔhàn louse fly virus 6 (WhLFV-6) \\
\hline & Mosquito mivirus & Wǔhàn mosquito virus 8 (WhMV-8) \\
\hline & Myriapod mivirus & Húběi myriapoda virus 8 (HbMV-8) \\
\hline & Odonate mivirus & Húběi odonate virus 11 (HbOV-11) \\
\hline & Sanxia mivirus & Sānxiá atyid shrimp virus 4 (SxASC-4) \\
\hline & Shayang mivirus & Shāyáng fly virus 1 (SyFV-1) \\
\hline & Suffolk mivirus & Suffolk virus (SFKV) \\
\hline & Taiyuan mivirus & Tàiyuán leafhopper virus (TYLeV) \\
\hline & Wenling mivirus & Wēnlǐng crustacean virus 15 (WlCV-15) \\
\hline & Wuhan mivirus & Wǔhàn tick virus 2 (WhTV-2) \\
\hline & Xinzhou mivirus & Xīnzhōu nematode virus 5 (XzNV-5) \\
\hline
\end{tabular}

Note that viruses are real objects that are assigned to concepts that are called taxa. Species, genera, families, and orders are taxa

*Type species

"Taxon names are always italicized and always begin with a capital letter

${ }^{\&}$ Virus names are not italicized and are not capitalized, except if the name or a name component is a proper noun. This column lists the virus names with their correct (lack of) capitalization. Lists of viruses within a given species are provisional at this point and will likely be amended in the near future 
Table 3 ICTV-accepted taxonomy of the order Mononegavirales (Negarnaviricota: Haploviricotina: Monjiviricetes) as of March 2020

\begin{tabular}{|c|c|c|}
\hline Genus & Species $^{\text {II }}$ & Virus $(\text { Abbreviation })^{\&}$ \\
\hline \multicolumn{3}{|c|}{ Family Artoviridae } \\
\hline \multirow[t]{2}{*}{ Hexartovirus } & Barnacle hexartovirus & Běihăi barnacle virus 8 (BhBV-8) \\
\hline & Caligid hexartovirus* & $\begin{array}{l}\text { Lepeophtheirus salmonis negative-stranded RNA virus } 1 \\
\text { (LsNSRV-1) }\end{array}$ \\
\hline \multirow[t]{6}{*}{ Peropuvirus } & Beihai peropuvirus & Běihǎi rhabdo-like virus 1 (BhRLV-1) \\
\hline & Hubei peropuvirus & Húběi rhabdo-like virus 6 (HbRLV-6) \\
\hline & Odonate peropuvirus & Húběi rhabdo-like virus 8 (HbRLV-8) \\
\hline & Pillworm peropuvirus & Húběi rhabdo-like virus 5 (HbRLV-5) \\
\hline & Pteromalus puparum peropuvirus* & $\begin{array}{l}\text { Pteromalus puparum negative-strand RNA virus } 1(\mathrm{PpN}- \\
\text { SRV-1) }\end{array}$ \\
\hline & Woodlouse peropuvirus & Běihăi rhabdo-like virus 2 (BhRLV-2) \\
\hline \multicolumn{3}{|c|}{ Family Bornaviridae } \\
\hline \multirow[t]{2}{*}{ Carbovirus } & Queensland carbovirus* & jungle carpet python virus (JCPV) \\
\hline & Southwest carbovirus & southwest carpet python virus (SWCPV) \\
\hline Cultervirus & Sharpbelly cultervirus* & Wǔhàn sharpbelly bornavirus (WhSBV) \\
\hline \multirow[t]{16}{*}{ Orthobornavirus } & Elapid 1 orthobornavirus & Loveridge's garter snake virus 1 (LGSV-1) \\
\hline & Mammalian 1 orthobornavirus* & Borna disease virus 1 (BoDV-1) \\
\hline & & Borna disease virus 2 (BoDV-2) \\
\hline & Mammalian 2 orthobornavirus & variegated squirrel bornavirus 1 (VSBV-1) \\
\hline & Passeriform 1 orthobornavirus & canary bornavirus $1(\mathrm{CnBV}-1)$ \\
\hline & & canary bornavirus $2(\mathrm{CnBV}-2)$ \\
\hline & & canary bornavirus $3(\mathrm{CnBV}-3)$ \\
\hline & Passeriform 2 orthobornavirus & estrildid finch bornavirus 1 (EsBV-1) \\
\hline & Psittaciform 1 orthobornavirus & parrot bornavirus $1(\mathrm{PaBV}-1)$ \\
\hline & & parrot bornavirus $2(\mathrm{PaBV}-2)$ \\
\hline & & parrot bornavirus $3(\mathrm{PaBV}-3)$ \\
\hline & & parrot bornavirus 4 (PaBV-4) \\
\hline & & parrot bornavirus 7 (PaBV-7) \\
\hline & Psittaciform 2 orthobornavirus & parrot bornavirus 5 (PaBV-5) \\
\hline & Waterbird 1 orthobornavirus & aquatic bird bornavirus 1 (ABBV-1) \\
\hline & & aquatic bird bornavirus $2(\mathrm{ABBV}-2)$ \\
\hline \multicolumn{3}{|l|}{ Family Filoviridae } \\
\hline Cuevavirus & Lloviu cuevavirus* & Lloviu virus (LLOV) \\
\hline Dianlovirus & Mengla dianlovirus* & Měnglà virus (MLAV) \\
\hline \multirow[t]{6}{*}{ Ebolavirus } & Bombali ebolavirus & Bombali virus (BOMV) \\
\hline & Bundibugyo ebolavirus & Bundibugyo virus (BDBV) \\
\hline & Reston ebolavirus & Reston virus (RESTV) \\
\hline & Sudan ebolavirus & Sudan virus (SUDV) \\
\hline & Tai Forest ebolavirus & Taï Forest virus (TAFV) \\
\hline & Zaire ebolavirus* & Ebola virus (EBOV) \\
\hline \multirow[t]{2}{*}{ Marburgvirus } & Marburg marburgvirus* & Marburg virus (MARV) \\
\hline & & Ravn virus (RAVV) \\
\hline Striavirus & Xilang striavirus* & Xīlăng virus (XILV) \\
\hline Thamnovirus & Huangjiao thamnovirus* & Huángjiāo virus (HUJV) \\
\hline \multicolumn{3}{|c|}{ Family Lispiviridae } \\
\hline \multirow[t]{5}{*}{ Arlivirus } & Gerrid arlivirus & Sānxiá water strider virus 4 (SxWSV-4) \\
\hline & Hubei arlivirus & Húběi rhabdo-like virus 3 (HbRLV-3) \\
\hline & Lishi arlivirus* & Líshí spider virus 2 (LsSV-2) \\
\hline & Odonate arlivirus & Húběi odonate virus 10 (HbOV-10) \\
\hline & Tacheng arlivirus & Tăchéng tick virus 6 (TcTV-6) \\
\hline
\end{tabular}


Table 3 (continued)

\begin{tabular}{|c|c|c|}
\hline Genus & Species ${ }^{\mathrm{I}}$ & Virus (Abbreviation) ${ }^{\&}$ \\
\hline & Wuchang arlivirus & Wǔchāng romanomermis nematode virus 2 (WcRNV-2) \\
\hline \multicolumn{3}{|c|}{ Family Mymonaviridae } \\
\hline \multirow[t]{2}{*}{ Hubramonavirus } & Hubei hubramonavirus* & Húběi rhabdo-like virus 4 (HbRLV-4) \\
\hline & Lentinula hubramonavirus & Lentinula edodes negative-strand RNA virus 1 (LeNSRV-1) \\
\hline \multirow[t]{10}{*}{ Sclerotimonavirus } & Dadou sclerotimonavirus & $\begin{array}{l}\text { soybean leaf-associated negative-stranded RNA virus } 3 \\
\text { (SLaNSRV-3) }\end{array}$ \\
\hline & Drop sclerotimonavirus & $\begin{array}{l}\text { Sclerotinia sclerotiorum negative-stranded RNA virus } 2 \\
\text { (SsNSRV-2) }\end{array}$ \\
\hline & & $\begin{array}{l}\text { Sclerotinia sclerotiorum negative-stranded RNA virus } 4 \\
\text { (SsNSRV-4) }\end{array}$ \\
\hline & Glycine sclerotimonavirus & $\begin{array}{l}\text { Fusarium graminearum negative-stranded RNA virus } 1 \\
\text { (FgNSRV-1) }\end{array}$ \\
\hline & & $\begin{array}{l}\text { soybean leaf-associated negative-stranded RNA virus } 1 \\
\text { (SLaNSRV-1) }\end{array}$ \\
\hline & Hubei sclerotimonavirus $[\mathrm{sic}]^{1}$ & \\
\hline & Illinois sclerotimonavirus & $\begin{array}{l}\text { soybean leaf-associated negative-stranded RNA virus } 2 \\
\text { (SLaNSRV-2) }\end{array}$ \\
\hline & Phyllosphere sclerotimonavirus & $\begin{array}{l}\text { soybean leaf-associated negative-stranded RNA virus } 4 \\
\text { (SLaNSRV-4) }\end{array}$ \\
\hline & Sclerotinia sclerotimonavirus* & $\begin{array}{l}\text { Sclerotinia sclerotiorum negative-stranded RNA virus } 1 \\
\text { (SsNSRV-1) }\end{array}$ \\
\hline & & $\begin{array}{l}\text { Sclerotinia sclerotiorum negative-stranded RNA virus } 3 \\
\text { (SsNSRV-3) }\end{array}$ \\
\hline \multicolumn{3}{|c|}{ Family Nyamiviridae } \\
\hline \multirow[t]{3}{*}{ Berhavirus } & Beihai berhavirus & Běihǎi rhabdo-like virus 4 (BhRLV-4) \\
\hline & Echinoderm berhavirus & Běihăi rhabdo-like virus 5 (BhRLV-5) \\
\hline & Sipunculid berhavirus* & Běihǎi rhabdo-like virus 3 (BhRLV-3) \\
\hline \multirow[t]{3}{*}{ Crustavirus } & Beihai crustavirus & Běihăi rhabdo-like virus 6 (BhRLV-6) \\
\hline & Wenling crustavirus & Wēnlíng crustacean virus 12 (WlCV-12) \\
\hline & Wenzhou crustavirus* & Wēnzhōu crab virus 1 (WzCV-1) \\
\hline \multirow[t]{3}{*}{ Nyavirus } & Midway nyavirus & Midway virus (MIDWV) \\
\hline & Nyamanini nyavirus* & Nyamanini virus (NYMV) \\
\hline & Sierra Nevada nyavirus & Sierra Nevada virus (SNVV) \\
\hline Orinovirus & Orinoco orinovirus* & Orinoco virus $(\mathrm{ONCV})$ \\
\hline Socyvirus & Soybean cyst nematode socyvirus* & soybean cyst nematode virus 1 (SbCNV-1) \\
\hline Tapwovirus & Tapeworm tapwovirus* & Wēnzhōu tapeworm virus 1 (WzTWV-1) \\
\hline \multicolumn{3}{|c|}{ Family Paramyxoviridae } \\
\hline \multicolumn{3}{|c|}{ Subfamily Avulavirinae } \\
\hline \multirow[t]{10}{*}{ Metaavulavirus } & Avian metaavulavirus $2 *$ & avian paramyxovirus $2(\mathrm{APMV}-2)$ \\
\hline & Avian metaavulavirus 5 & avian paramyxovirus 5 (APMV-5) \\
\hline & Avian metaavulavirus 6 & avian paramyxovirus 6 (APMV-6) \\
\hline & Avian metaavulavirus 7 & avian paramyxovirus 7 (APMV-7) \\
\hline & Avian metaavulavirus 8 & avian paramyxovirus 8 (APMV-8) \\
\hline & Avian metaavulavirus 10 & avian paramyxovirus 10 (APMV-10) \\
\hline & Avian metaavulavirus 11 & avian paramyxovirus 11 (APMV-11) \\
\hline & Avian metaavulavirus 14 & avian paramyxovirus 14 (APMV-14) \\
\hline & Avian metaavulavirus 15 & avian paramyxovirus 15 (APMV-15) \\
\hline & Avian metaavulavirus 20 & avian paramyxovirus 20 (APMV-20) \\
\hline \multirow[t]{3}{*}{ Orthoavulavirus } & Avian orthoavulavirus $1 *$ & avian paramyxovirus $1(\mathrm{APMV}-1)^{2}$ \\
\hline & Avian orthoavulavirus 9 & avian paramyxovirus 9 (APMV-9) \\
\hline & Avian orthoavulavirus 12 & avian paramyxovirus 12 (APMV-12) \\
\hline
\end{tabular}


Table 3 (continued)

\begin{tabular}{|c|c|c|}
\hline Genus & Species ${ }^{\mathrm{I}}$ & Virus (Abbreviation) ${ }^{\&}$ \\
\hline & Avian orthoavulavirus 13 & avian paramyxovirus 13 (APMV-13) \\
\hline & Avian orthoavulavirus 16 & avian paramyxovirus 16 (APMV-16) \\
\hline & Avian orthoavulavirus 17 & Antarctic penguin virus A (APV-A) \\
\hline & Avian orthoavulavirus 18 & Antarctic penguin virus B (APV-B) \\
\hline & Avian orthoavulavirus 19 & Antarctic penguin virus $\mathrm{C}$ (APV-C) \\
\hline & Avian orthoavulavirus 21 & avian paramyxovirus 21 (APMV-21) \\
\hline & Avian orthovulavirus $21[\mathrm{sic}]^{3}$ & \\
\hline \multirow[t]{2}{*}{ Paraavulavirus } & Avian paraavulavirus $3 *$ & avian paramyxovirus 3 (APMV-3) \\
\hline & Avian paraavulavirus 4 & avian paramyxovirus 4 (APMV-4) \\
\hline \multicolumn{3}{|c|}{ Subfamily Metaparamyxovirinae } \\
\hline Synodonvirus & Synodus synodonvirus* & Wēnlǐng triplecross lizardfish paramyxovirus (WTLPV) \\
\hline \multicolumn{3}{|c|}{ Subfamily Orthoparamyxovirinae } \\
\hline \multirow[t]{2}{*}{ Aquaparamyxovirus } & Oncorhynchus aquaparamyxovirus & Pacific salmon paramyxovirus (PSPV) \\
\hline & Salmo aquaparamyxovirus* & Atlantic salmon paramyxovirus (AsaPV) \\
\hline Ferlavirus & Reptilian ferlavirus* & fer-de-lance virus (FDLV) \\
\hline \multirow[t]{5}{*}{ Henipavirus } & Cedar henipavirus & Cedar virus $(\mathrm{CedV})$ \\
\hline & Ghanaian bat henipavirus & Ghana virus (GhV) \\
\hline & Hendra henipavirus* & Hendra virus $(\mathrm{HeV})$ \\
\hline & Mojiang henipavirus & Mòjiāng virus (MojV) \\
\hline & Nipah henipavirus & Nipah virus (NiV) \\
\hline \multirow[t]{7}{*}{ Jeilongvirus } & Beilong jeilongvirus* & Beilong virus (BeiV) \\
\hline & Jun jeilongvirus & $\mathrm{J}$ virus (JV) \\
\hline & Lophuromys jeilongvirus 1 & Mount Mabu Lophuromys virus 1 (MMLV-1) \\
\hline & Lophuromys jeilongvirus 2 & Mount Mabu Lophuromys virus 2 (MMLV-2) \\
\hline & Miniopteran jeilongvirus & Shaan virus (ShaV) \\
\hline & Myodes jeilongvirus & Pohorje Myodes paramyxovirus 1 (PMPV-1) \\
\hline & Tailam jeilongvirus & Tailam virus (TaiV) \\
\hline \multirow[t]{7}{*}{ Morbillivirus } & Canine morbillivirus & canine distemper virus (CDV) \\
\hline & Cetacean morbillivirus & cetacean morbillivirus (CeMV) \\
\hline & Feline morbillivirus & feline morbillivirus (FeMV) \\
\hline & Measles morbillivirus* & measles virus $(\mathrm{MeV})$ \\
\hline & Phocine morbillivirus & phocine distemper virus (PDV) \\
\hline & Rinderpest morbillivirus & rinderpest virus (RPV) \\
\hline & Small ruminant morbillivirus & peste-des-petits-ruminants virus (PPRV) \\
\hline \multirow[t]{4}{*}{ Narmovirus } & Mossman narmovirus & Mossman virus (MossV) \\
\hline & Myodes narmovirus & bank vole virus $1(\mathrm{BaV}-1)$ \\
\hline & Nariva narmovirus* & Nariva virus (NarV) \\
\hline & Tupaia narmovirus & Tupaia paramyxovirus (TupV) \\
\hline \multirow[t]{7}{*}{ Respirovirus } & Bovine respirovirus 3 & bovine parainfluenza virus 3 (BPIV-3) \\
\hline & Caprine respirovirus 3 & caprine parainfluenzavirus 3 (CPIV-3) \\
\hline & Human respirovirus 1 & human parainfluenza virus 1 (HPIV-1) \\
\hline & Human respirovirus 3 & human parainfluenza virus 3 (HPIV-3) \\
\hline & Murine respirovirus* & Sendai virus $(\mathrm{SeV})$ \\
\hline & Porcine respirovirus 1 & porcine parainfluenza virus 1 (PPIV-1) \\
\hline & Squirrel respirovirus & giant squirrel virus (GSqV) \\
\hline Salemvirus & Salem salemvirus* & Salem virus (SalV) \\
\hline \multicolumn{3}{|c|}{ Subfamily Rubulavirinae } \\
\hline \multirow[t]{3}{*}{ Orthorubulavirus } & Human orthorubulavirus 2 & human parainfluenza virus 2 (HPIV-2) \\
\hline & Human orthorubulavirus 4 & human parainfluenza virus $4 \mathrm{a}$ (HPIV-4a) \\
\hline & & human parainfluenza virus 4b (HPIV-4b) \\
\hline
\end{tabular}


Table 3 (continued)

\begin{tabular}{|c|c|c|}
\hline Genus & Species $^{\mathbb{I I}}$ & Virus (Abbreviation) ${ }^{\&}$ \\
\hline & Mammalian orthorubulavirus 5 & parainfluenza virus 5 (PIV-5) \\
\hline & Mammalian orthorubulavirus 6 & Alston virus (AlsV) \\
\hline & Mapuera orthorubulavirus & Mapuera virus (MapV) \\
\hline & Mumps orthorubulavirus* & mumps virus $(\mathrm{MuV})$ \\
\hline & Porcine orthorubulavirus & La Piedad Michoacán Mexico virus (LPMV) \\
\hline & Simian orthorubulavirus & simian virus $41(\mathrm{SV}-41)$ \\
\hline \multirow[t]{10}{*}{ Pararubulavirus } & Achimota pararubulavirus 1 & Achimota virus 1 (AchPV-1) \\
\hline & Achimota pararubulavirus 2 & Achimota virus 2 (AchPV-2) \\
\hline & Hervey pararubulavirus & Hervey virus (HerV) \\
\hline & Menangle pararubulavirus* & Menangle virus (MenPV) \\
\hline & Sosuga pararubulavirus & Sosuga virus (SOSV) \\
\hline & Teviot pararubulavirus & Teviot virus (TevPV) \\
\hline & Tioman pararubulavirus & Tioman virus (TioPV) \\
\hline & Tuhoko pararubulavirus 1 & Tuhoko virus 1 (ThkPV-1) \\
\hline & Tuhoko pararubulavirus 2 & Tuhoko virus 2 (ThkPV-2) \\
\hline & Tuhoko pararubulavirus 3 & Tuhoko virus 3 (ThkPV-3) \\
\hline \multicolumn{3}{|l|}{ Unassigned (to subfamilies) } \\
\hline Cynoglossusvirus & Cynoglossus cynoglossusvirus* & Wēnlı̌ng tonguesole paramyxovirus (WTSPV) \\
\hline Hoplichthysvirus & Hoplichthys hoplichthysvirus* & Wēnlǐng hoplichthys paramyxovirus (WHPV) \\
\hline Scoliodonvirus & Scoliodon scoliodonvirus* & Wēnzhōu pacific spadenose shark paramyxovirus (WPSSPV) \\
\hline \multicolumn{3}{|l|}{ Family Pneumoviridae } \\
\hline \multirow[t]{2}{*}{ Metapneumovirus } & Avian metapneumovirus* & avian metapneumovirus (AMPV) \\
\hline & Human metapneumovirus & human metapneumovirus (HMPV) \\
\hline \multirow[t]{3}{*}{ Orthopneumovirus } & Bovine orthopneumovirus & bovine respiratory syncytial virus (BRSV) \\
\hline & Human orthopneumovirus* & human respiratory syncytial virus (HRSV) \\
\hline & Murine orthopneumovirus & murine pneumonia virus (MPV) \\
\hline \multicolumn{3}{|l|}{ Family Rhabdoviridae } \\
\hline \multirow[t]{6}{*}{ Almendravirus } & Arboretum almendravirus & Arboretum virus (ABTV) \\
\hline & Balsa almendravirus & Balsa virus (BALV) \\
\hline & Coot Bay almendravirus & Coot Bay virus (CBV) \\
\hline & Menghai almendravirus & Menghai virus (MRV) \\
\hline & Puerto Almendras almendravirus* & Puerto Almendras virus (PTAMV) \\
\hline & Rio Chico almendravirus & Rio Chico virus (RCHV) \\
\hline \multirow[t]{2}{*}{ Alphanemrhavirus } & Xingshan alphanemrhavirus* & Xingshan nematode virus 4 (XsNV-4) \\
\hline & Xinzhou alphanemrhavirus & Xinzhou nematode virus 4 (XzNV-4) \\
\hline \multirow[t]{10}{*}{ Alphanucleorhabdovirus } & $\begin{array}{l}\text { Eggplant mottled dwarf alphanucleorhab- } \\
\text { dovirus }\end{array}$ & eggplant mottled dwarf virus (EMDV) \\
\hline & Maize Iranian mosaic alphanucleorhabdovirus & maize Iranian mosaic virus (MIMV) \\
\hline & Maize mosaic alphanucleorhabdovirus & maize mosaic virus (MMV) \\
\hline & $\begin{array}{l}\text { Morogoro maize-associated alphanucleorhab } \\
\text { dovirus }\end{array}$ & - Morogoro maize-associated virus (MMaV) \\
\hline & $\begin{array}{l}\text { Physostegia chlorotic mottle alphanucle- } \\
\text { orhabdovirus }\end{array}$ & Physostegia chlorotic mottle virus ( $\mathrm{PhCMoV}$ ) \\
\hline & Potato yellow dwarf alphanucleorhabdovirus & * potato yellow dwarf virus (PYDV) \\
\hline & Rice yellow stunt alphanucleorhabdovirus & rice yellow stunt virus (RYSV) \\
\hline & & rice transitory yellowing virus (RTYV) \\
\hline & Taro vein chlorosis alphanucleorhabdovirus & taro vein chlorosis virus ( $\mathrm{TaVCV})$ \\
\hline & Wheat yellow striate alphanucleorhabdovirus & wheat yellow striate virus (WYSV) \\
\hline \multirow[t]{3}{*}{ Arurhavirus } & Aruac arurhavirus* & Aruac virus (ARUV) \\
\hline & Inhangapi arurhavirus & Inhangapi virus (INHV) \\
\hline & Santabarbara arurhavirus & Santa Barbara virus (SBAV) \\
\hline
\end{tabular}


Table 3 (continued)

\begin{tabular}{|c|c|c|}
\hline Genus & Species ${ }^{\mathrm{II}}$ & Virus (Abbreviation) ${ }^{\&}$ \\
\hline & Xiburema arurhavirus & Xiburema virus (XIBV) \\
\hline \multirow[t]{3}{*}{ Barhavirus } & Bahia barhavirus* & Bahia Grande virus (BGV) \\
\hline & & Harlingen virus (HARV) \\
\hline & Muir barhavirus & Muir Springs virus (MSV) \\
\hline \multirow[t]{6}{*}{ Betanucleorhabdovirus } & Alfalfa betanucleorhabdovirus & alfalfa-associated nucleorhabdovirus (AaNV) \\
\hline & Blackcurrant betanucleorhabdovirus & blackcurrant-associated rhabdovirus (BCaRV) \\
\hline & Datura yellow vein betanucleorhabdovirus & datura yellow vein virus (DYVV) \\
\hline & Sonchus yellow net betanucleorhabdovirus $*$ & Sonchus yellow net virus (SYNV) \\
\hline & Sowthistle yellow vein betanucleorhabdovirus & sowthistle yellow vein virus (SYVV) \\
\hline & Trefoil betanucleorhabdovirus & birds-foot trefoil-associated virus (BFTV) \\
\hline \multirow[t]{3}{*}{ Caligrhavirus } & Caligus caligrhavirus & Caligus rogercresseyi rhabdovirus (CRogRV) \\
\hline & Lepeophtheirus caligrhavirus* & Lepeophtheirus salmonis rhabdovirus 127 (LSalRV-127) \\
\hline & Salmonlouse caligrhavirus & Lepeophtheirus salmonis rhabdovirus 9 (LSalRV-9) \\
\hline \multirow[t]{4}{*}{ Curiovirus } & Curionopolis curiovirus* & Curionopolis virus (CURV) \\
\hline & Iriri curiovirus & Iriri virus (IRIRV) \\
\hline & Itacaiunas curiovirus & Itacaiunas virus (ITAV) \\
\hline & Rochambeau curiovirus & Rochambeau virus (RBUV) \\
\hline \multirow[t]{23}{*}{ Cytorhabdovirus } & Alfalfa dwarf cytorhabdovirus & alfalfa dwarf virus (ADV) \\
\hline & Barley yellow striate mosaic cytorhabdovirus & barley yellow striate mosaic virus (BYSMV) \\
\hline & Broccoli necrotic yellows cytorhabdovirus & broccoli necrotic yellows virus (BNYV) \\
\hline & Cabbage cytorhabdovirus & cabbage cytorhabdovirus $1(\mathrm{CCyV}-1)$ \\
\hline & $\begin{array}{l}\text { Colocasia bobone disease-associated } \\
\text { cytorhabdovirus }\end{array}$ & Colocasia bobone disease-associated virus $(\mathrm{CBDaV})$ \\
\hline & Festuca leaf streak cytorhabdovirus & Festuca leaf streak virus (FLSV) \\
\hline & Lettuce necrotic yellows cytorhabdovirus* & lettuce necrotic yellows virus (LNYV) \\
\hline & Lettuce yellow mottle cytorhabdovirus & lettuce yellow mottle virus (LYMoV) \\
\hline & Maize-associated cytorhabdovirus & maize-associated cytorhabdovirus (MaCV) \\
\hline & Maize yellow striate cytorhabdovirus & maize yellow striate virus (MYSV) \\
\hline & Northern cereal mosaic cytorhabdovirus & northern cereal mosaic virus (NCMV) \\
\hline & Papaya cytorhabdovirus & papaya virus $\mathrm{E}(\mathrm{PpVE})$ \\
\hline & Persimmon cytorhabdovirus & persimmon virus $\mathrm{A}(\mathrm{PeVA})$ \\
\hline & Raspberry vein chlorosis cytorhabdovirus & raspberry vein chlorosis virus (RVCV) \\
\hline & Rice stripe mosaic cytorhabdovirus & rice stripe mosaic virus (RSMV) \\
\hline & Sonchus cytorhabdovirus 1 & Sonchus virus (SonV) \\
\hline & Strawberry crinkle cytorhabdovirus & strawberry crinkle virus (SCV) \\
\hline & Tomato yellow mottle-associated cytorhabdovirus & somato yellow mottle-associated virus (TYMaV) \\
\hline & Wheat American striate mosaic cytorhabdovirus & wheat American striate mosaic virus (WASMV) \\
\hline & Wuhan 4 insect cytorhabdovirus & Wuhan insect virus 4 (WuIV-4) \\
\hline & Wuhan 5 insect cytorhabdovirus & Wuhan insect virus 5 (WuIV-5) \\
\hline & Wuhan 6 insect cytorhabdovirus & Wuhan insect virus 6 (WuIV-6) \\
\hline & $\begin{array}{l}\text { Yerba mate chlorosis-associated cytorhab- } \\
\text { dovirus }\end{array}$ & yerba mate chlorosis-associated virus ( $\mathrm{YmCaV})$ \\
\hline \multirow[t]{5}{*}{ Dichorhavirus } & Citrus chlorotic spot dichorhavirus & citrus chlorotic spot virus (CiCSV) \\
\hline & Citrus leprosis $N$ dichorhavirus & citrus leprosis virus $\mathrm{N}(\mathrm{CiLV}-\mathrm{N})$ \\
\hline & Clerodendrum chlorotic spot dichorhavirus & clerodendrum chlorotic spot virus (ClCSV) \\
\hline & Coffee ringspot dichorhavirus & coffee ringspot virus (CoRSV) \\
\hline & Orchid fleck dichorhavirus* & orchid fleck virus (OFV) \\
\hline \multirow[t]{4}{*}{ Ephemerovirus } & Adelaide River ephemerovirus & Adelaide River virus (ARV) \\
\hline & Berrimah ephemerovirus & Berrimah virus (BRMV) \\
\hline & Bovine fever ephemerovirus* & bovine ephemeral fever virus (BEFV) \\
\hline & Kimberley ephemerovirus & Kimberley virus (KIMV) \\
\hline
\end{tabular}


Table 3 (continued)

\begin{tabular}{|c|c|c|}
\hline Genus & Species ${ }^{\text {II }}$ & Virus (Abbreviation) ${ }^{\&}$ \\
\hline & & Malakal virus (MALV) \\
\hline & Koolpinyah ephemerovirus & Koolpinyah virus (KOOLV) \\
\hline & Kotonkan ephemerovirus & kotonkan virus (KOTV) \\
\hline & Obodhiang ephemerovirus & Obodhiang virus (OBOV) \\
\hline & Yata ephemerovirus & Yata virus (YATV) \\
\hline Gammanucleorhabdovirus & Maize fine streak gammanucleorhabdovirus & maize fine streak virus (MFSV) \\
\hline \multirow[t]{16}{*}{ Hapavirus } & Flanders hapavirus* & Flanders virus (FLAV) \\
\hline & Gray Lodge hapavirus & Gray Lodge virus (GLOV) \\
\hline & Hart Park hapavirus & Hart Park virus (HPV) \\
\hline & Holmes hapavirus & Holmes Jungle virus (HOJV) \\
\hline & Joinjakaka hapavirus & Joinjakaka virus (JOIV) \\
\hline & Kamese hapavirus & Kamese virus (KAMV) \\
\hline & La Joya hapavirus & La Joya virus (LJV) \\
\hline & Landjia hapavirus & Landjia virus (LANV = LJAV) \\
\hline & Manitoba hapavirus & Manitoba virus (MANV = MNTBV) \\
\hline & Marco hapavirus & Marco virus (MCOV) \\
\hline & Mosqueiro hapavirus & Mosqueiro virus (MQOV) \\
\hline & Mossuril hapavirus & Mossuril virus (MOSV) \\
\hline & Ngaingan hapavirus & Ngaingan virus (NGAV) \\
\hline & Ord River hapavirus & Ord River virus (ORV) \\
\hline & Parry Creek hapavirus & Parry Creek virus (PCV) \\
\hline & Wongabel hapavirus & Wongabel virus (WONV) \\
\hline \multirow[t]{16}{*}{ Ledantevirus } & Barur ledantevirus & Barur virus (BARV) \\
\hline & Fikirini ledantevirus & Fikirini virus (FKRV) \\
\hline & Fukuoka ledantevirus & Fukuoka virus (FUKV) \\
\hline & Kanyawara ledantevirus & Kanyawara virus (KYAV) \\
\hline & Kern Canyon ledantevirus & Kern Canyon virus (KCV) \\
\hline & Keuraliba ledantevirus & Keuraliba virus (KEUV) \\
\hline & Kolente ledantevirus & Kolente virus (KOLEV) \\
\hline & Kumasi ledantevirus & Kumasi rhabdovirus (KRV) \\
\hline & Le Dantec ledantevirus* & Le Dantec virus (LDV) \\
\hline & Mount Elgon bat ledantevirus & Mount Elgon bat virus (MEBV) \\
\hline & Nishimuro ledantevirus & Nishimuro virus (NISV) \\
\hline & Nkolbisson ledantevirus & Nkolbisson virus (NKOV) \\
\hline & Oita ledantevirus & Oita virus (OITAV) \\
\hline & Vaprio ledantevirus & Vaprio virus (VAPV) \\
\hline & Wuhan ledantevirus & Wuhan louse fly virus 5 (WLFV-5) \\
\hline & Yongjia ledantevirus & Yongjia tick virus 2 (YTV-2) \\
\hline Lostrhavirus & Lonestar zarhavirus $* 4$ & lone star tick rhabdovirus (LITRV) \\
\hline \multirow[t]{12}{*}{ Lyssavirus } & Aravan lyssavirus & Aravan virus (ARAV) \\
\hline & Australian bat lyssavirus & Australian bat lyssavirus (ABLV) \\
\hline & Bokeloh bat lyssavirus & Bokeloh bat lyssavirus (BBLV) \\
\hline & Duvenhage lyssavirus & Duvenhage virus (DUVV) \\
\hline & European bat 1 lyssavirus & European bat lyssavirus 1 (EBLV-1) \\
\hline & European bat 2 lyssavirus & European bat lyssavirus 2 (EBLV-2) \\
\hline & Gannoruwa bat lyssavirus & Gannoruwa bat lyssavirus (GBLV) \\
\hline & Ikoma lyssavirus & Ikoma lyssavirus (IKOV) \\
\hline & Irkut lyssavirus & Irkut virus (IRKV) \\
\hline & Khujand lyssavirus & Khujand virus (KHUV) \\
\hline & Lagos bat lyssavirus & Lagos bat virus (LBV) \\
\hline & Lleida bat lyssavirus & Lleida bat lyssavirus (LLEBV) \\
\hline
\end{tabular}


Table 3 (continued)

\begin{tabular}{|c|c|c|}
\hline Genus & Species $^{\mathbb{I I}}$ & Virus (Abbreviation) ${ }^{\&}$ \\
\hline & Mokola lyssavirus & Mokola virus (MOKV) \\
\hline & Rabies lyssavirus* & rabies virus (RABV) \\
\hline & Shimoni bat lyssavirus & Shimoni bat virus (SHIBV) \\
\hline & Taiwan bat lyssavirus & Taiwan bat lyssavirus (TWBLV) \\
\hline & West Caucasian bat lyssavirus & West Caucasian bat virus (WCBV) \\
\hline Mousrhavirus & Moussa mousrhavirus* & Moussa virus (MOUV) \\
\hline \multirow[t]{4}{*}{ Novirhabdovirus } & Hirame novirhabdovirus & hirame rhabdovirus (HIRRV = HIRV) \\
\hline & Piscine novirhabdovirus & viral hemorrhagic septicemia virus (VHSV) \\
\hline & Salmonid novirhabdovirus* & infectious hematopoietic necrosis virus (IHNV) \\
\hline & Snakehead novirhabdovirus & snakehead rhabdovirus (SHRV) \\
\hline \multirow[t]{5}{*}{ Ohlsrhavirus } & Ohlsdorf ohlsrhavirus & Ohlsdorf virus (OHLDV) \\
\hline & Tongilchon ohlsrhavirus & Tongilchon virus 1 (TCHV-1) \\
\hline & Riverside ohlsrhavirus & Riverside virus (RISV) \\
\hline & Culex ohlsrharhavirus & Culex rhabdo-like virus (CRLV) \\
\hline & Northcreek ohlsrhavirus & North Creek virus (NORCV) \\
\hline \multirow[t]{3}{*}{ Perhabdovirus } & Anguillid perhabdovirus & eel virus European X (EVEX) \\
\hline & Perch perhabdovirus* & perch rhabdovirus (PRV) \\
\hline & Sea trout perhabdovirus & lake trout rhabdovirus (LTRV) \\
\hline \multirow[t]{4}{*}{ Sawgrhavirus } & Connecticut sawgrhavirus & Connecticut virus (CNTV) \\
\hline & Island sawgrhavirus & Long Island tick rhabdovirus (LITRV) \\
\hline & Minto sawgrhavirus & New Minto virus (NMV) \\
\hline & Sawgrass sawgrhavirus* & Sawgrass virus (SAWV) \\
\hline \multirow[t]{7}{*}{ Sigmavirus } & Drosophila affinis sigmavirus & Drosophila affinis sigmavirus (DAffSV) \\
\hline & Drosophila ananassae sigmavirus & Drosophila ananassae sigmavirus (DAnaSV) \\
\hline & Drosophila immigrans sigmavirus & Drosophila immigrans sigmavirus (DImmSV) \\
\hline & Drosophila melanogaster sigmavirus* & Drosophila melanogaster sigmavirus (DMelSV) \\
\hline & Drosophila obscura sigmavirus & Drosophila obscura sigmavirus (DObsSV) \\
\hline & Drosophila tristis sigmavirus & Drosophila tristis sigmavirus (DTriSV) \\
\hline & Muscina stabulans sigmavirus & Muscina stabulans sigmavirus (MStaSV) \\
\hline \multirow[t]{4}{*}{ Sprivivirus } & Carp sprivivirus* & spring viremia of carp virus (SVCV) \\
\hline & Pike fry sprivivirus & grass carp rhabdovirus (GrCRV) \\
\hline & & pike fry rhabdovirus (PFRV) \\
\hline & & tench rhabdovirus (TenRV) \\
\hline \multirow[t]{8}{*}{ Sripuvirus } & Almpiwar sripuvirus & Almpiwar virus (ALMV) \\
\hline & Chaco sripuvirus & Chaco virus $(\mathrm{CHOV})$ \\
\hline & Charleville sripuvirus & Charleville virus (CHVV) \\
\hline & Cuiaba sripuvirus & Cuiaba virus (CUIV) \\
\hline & Hainan sripuvirus & Hainan black-spectacled toad rhabdovirus (HnBSTRV) \\
\hline & Niakha sripuvirus* & Niakha virus (NIAV) \\
\hline & Sena Madureira sripuvirus & Sena Madureira virus (SMV) \\
\hline & Sripur sripuvirus & Sripur virus (SRIV) \\
\hline \multirow[t]{6}{*}{ Sunrhavirus } & Garba sunrhavirus & Garba virus (GARV) \\
\hline & Harrison sunrhavirus & Harrison Dam virus (HARDV) \\
\hline & Kwatta sunrhavirus & Kwatta virus (KWAV) \\
\hline & Oakvale sunrhavirus & Oak Vale virus (OVV) \\
\hline & Sunguru sunrhavirus* & Sunguru virus (SUNV) \\
\hline & Walkabout sunrhavirus & Walkabout Creek virus (WAKV) \\
\hline \multirow[t]{3}{*}{ Tibrovirus } & Bas Congo tibrovirus & Bas-Congo virus (BASV) \\
\hline & Beatrice Hill tibrovirus & Beatrice Hill virus (BHV) \\
\hline & Coastal Plains tibrovirus & Coastal Plains virus (CPV) \\
\hline
\end{tabular}


Table 3 (continued)

\begin{tabular}{|c|c|c|}
\hline Genus & Species $^{\text {TI }}$ & Virus (Abbreviation) $)^{\&}$ \\
\hline & Ekpoma 1 tibrovirus & Ekpoma virus 1 (EKV-1) \\
\hline & Ekpoma 2 tibrovirus & Ekpoma virus 2 (EKV-2) \\
\hline & Sweetwater Branch tibrovirus & Sweetwater Branch virus (SWBV) \\
\hline & Tibrogargan tibrovirus* & Bivens Arm virus (BAV) \\
\hline & & Tibrogargan virus (TIBV) \\
\hline \multirow[t]{3}{*}{ Tupavirus } & Durham tupavirus* & Durham virus (DURV) \\
\hline & Klamath tupavirus & Klamath virus (KLAV) \\
\hline & Tupaia tupavirus & tupaia rhabdovirus (TUPV) \\
\hline Varicosavirus & Lettuce big-vein associated varicosavirus* & lettuce big-vein associated virus (LBVaV) \\
\hline \multirow[t]{16}{*}{ Vesiculovirus } & Alagoas vesiculovirus & vesicular stomatitis Alagoas virus (VSAV) \\
\hline & American bat vesiculovirus & American bat vesiculovirus (ABVV) \\
\hline & Carajas vesiculovirus & Carajas virus (CJSV) \\
\hline & Chandipura vesiculovirus & Chandipura virus (CHPV) \\
\hline & Cocal vesiculovirus & Cocal virus $(\mathrm{COCV})$ \\
\hline & Indiana vesiculovirus* & vesicular stomatitis Indiana virus (VSIV) \\
\hline & Isfahan vesiculovirus & Isfahan virus (ISFV) \\
\hline & Jurona vesiculovirus & Jurona virus (JURV) \\
\hline & Malpais Spring vesiculovirus & Malpais Spring virus (MSPV) \\
\hline & Maraba vesiculovirus & Maraba virus (MARAV) \\
\hline & Morreton vesiculovirus & Morreton virus (MORV) \\
\hline & New Jersey vesiculovirus & vesicular stomatitis New Jersey virus (VSNJV) \\
\hline & Perinet vesiculovirus & Perinet virus (PERV) \\
\hline & Piry vesiculovirus & Piry virus (PIRYV) \\
\hline & Radi vesiculovirus & Radi virus (RADV) \\
\hline & Yug Bogdanovac vesiculovirus & Yug Bogdanovac virus (YBV) \\
\hline Zarhavirus & Zahedan zarhavirus* & Zahedan rhabdovirus (ZARV) \\
\hline \multicolumn{3}{|c|}{ Family Sunviridae } \\
\hline Sunshinevirus & Reptile sunshinevirus $1^{*}$ & Sunshine Coast virus (SunCV) \\
\hline \multicolumn{3}{|c|}{ Family Xinmoviridae } \\
\hline \multirow[t]{8}{*}{ Anphevirus } & Bolahun anphevirus & Bolahun virus (BLHV) \\
\hline & & Gambie virus (GAMV) \\
\hline & Dipteran anphevirus & Húběi diptera virus 11 (HbDV-11) \\
\hline & Drosophilid anphevirus & Drosophila unispina virus 1 (DuniV-1) \\
\hline & Odonate anphevirus & Húběi rhabdo-like virus 7 (HbRLV-7) \\
\hline & Orthopteran anphevirus & Húběi orthoptera virus 5 (HbOV-5) \\
\hline & Shuangao anphevirus & Shuāngào fly virus 2 (SgFV-2) \\
\hline & Xincheng anphevirus* & Xīnchéng mosquito virus (XcMV) \\
\hline
\end{tabular}

Note that viruses are real objects that are assigned to concepts that are called taxa. Species, genera, subfamilies, families, and orders are taxa

*Type species

${ }^{1}$ Due to a formal classification mistake this species was not deleted. A proposal to delete this species has been submitted

${ }^{2}$ Includes: Newcastle disease virus (NDV)

${ }^{3}$ Due to a formal classification mistake, this species was incorrectly named Avian orthovulavirus 21 in TaxoProp $2019.014 \mathrm{M} . \mathrm{A} . \mathrm{v} 1$. Avulavirus_1newsp but correctly named Avian orthoavulavirus 21 in TaxoProp 2019.025M.A.v2.Paramyxoviridae_3gen5sp4rensp. Hence as of now, both species names are official. A proposal to correct this mistake has been submitted

${ }^{4}$ Due to a formal classification mistake this species was named Lonestar zarhavirus instead of Lonestar lostrhavirus. A proposal to correct this mistake has been submitted

II Taxon names are always italicized and always begin with a capital letter

${ }^{\&}$ Virus names are not italicized and are not capitalized, except if the name or a name component is a proper noun. This column lists the virus names with their correct (lack of) capitalization. Lists of viruses within a given species are provisional at this point and will likely be amended in the near future 
Table 4 ICTV-accepted taxonomy of the order Muvirales (Negarnaviricota: Haploviricotina: Chunqiuviricetes) as of March 2020

\begin{tabular}{lll}
\hline Genus & Species $^{\text {II }}$ & Virus (Abbreviation) $^{\&}$ \\
\hline Family Qinviridae & & \\
Yingvirus & Beihai yingvirus & Běihăi sesarmid crab virus 4 (BhSCV-4) \\
& Charybdis yingvirus & Wēnzhōu qínvirus-like virus 2(WzQLV-2) \\
& Hubei yingvirus & Húběi qínvirus-like virus 1 (HbQLV-1) \\
& Sanxia yingvirus & Sānxiá qínvirus-like virus 1 (SxQLV-1) \\
& Shahe yingvirus & Shāhé qínvirus-like virus 1 (ShQLV-1) \\
& Wenzhou yingvirus & Wēnzhōu qínvirus-like virus 1 (WzQLV-1) \\
& Wuhan yingvirus* & Wǔhàn insect virus 15 (WhIV-15) \\
& Xinzhou yingvirus & X̄inzhōu nematode virus 3 (XzNV-3) \\
\hline
\end{tabular}

Note that viruses are real objects that are assigned to concepts that are called taxa. Species, genera, families, and orders are taxa

*Type species

IITaxon names are always italicized and always begin with a capital letter

${ }^{\&}$ Virus names are not italicized and are not capitalized, except if the name or a name component is a proper noun. This column lists the virus names with their correct (lack of) capitalization. Lists of viruses within a given species are provisional at this point and will likely be amended in the near future

Table 5 ICTV-accepted taxonomy of the order Serpentovirales (Negarnaviricota: Haploviricotina: Milneviricetes) as of March 2020

\begin{tabular}{lll}
\hline Genus & Species $^{\text {II }}$ & Virus (Abbreviation) $^{\&}$ \\
\hline Family Aspiviridae & & \\
Ophiovirus & Blueberry mosaic associated ophiovirus & blueberry mosaic associated virus (BlMaV) \\
& Citrus psorosis ophiovirus* & citrus psorosis virus (CPsV) \\
& Freesia sneak ophiovirus & freesia sneak virus (FreSV) \\
& Lettuce ring necrosis ophiovirus & lettuce ring necrosis virus (LRNV) \\
& Mirafiori lettuce big-vein ophiovirus & Mirafiori lettuce big-vein virus (MLBVV) \\
& Ranunculus white mottle ophiovirus & ranunculus white mottle virus (RWMV) \\
& Tulip mild mottle mosaic ophiovirus & tulip mild mottle mosaic virus (TMMMV) \\
\hline
\end{tabular}

Note that viruses are real objects that are assigned to concepts that are called taxa. Species, genera, families, and orders are taxa

*Type species

ITaxon names are always italicized and always begin with a capital letter

${ }^{\&}$ Virus names are not italicized and are not capitalized, except if the name or a name component is a proper noun. This column lists the virus names with their correct (lack of) capitalization. Lists of viruses within a given species are provisional at this point and will likely be amended in the near future

Table 6 ICTV-accepted taxonomy of the order Articulavirales (Negarnaviricota: Polyploviricotina: Insthoviricetes) as of March 2020

\begin{tabular}{|c|c|c|}
\hline Genus & Species $^{\mathbb{I}}$ & Virus (Abbreviation) ${ }^{\&}$ \\
\hline \multicolumn{3}{|l|}{ Family Amnoonviridae } \\
\hline Tilapinevirus & Tilapia tilapinevirus* & tilapia lake virus (TiLV) \\
\hline \multicolumn{3}{|c|}{ Family Orthomyxoviridae } \\
\hline Alphainfluenzavirus & Influenza A virus* & influenza A virus (FLUAV) \\
\hline Betainfluenzavirus & Influenza $B$ virus* & influenza B virus (FLUBV) \\
\hline Deltainfluenzavirus & Influenza $D$ virus* & influenza D virus (FLUDV) \\
\hline Gammainfluenzavirus & Influenza $C$ virus* & influenza $\mathrm{C}$ virus (FLUCV) \\
\hline Isavirus & Salmon isavirus* & infectious salmon anemia virus (ISAV) \\
\hline \multirow[t]{2}{*}{ Quaranjavirus } & Johnston Atoll quaranjavirus & Johnston Atoll virus (JAV) \\
\hline & Quaranfil quaranjavirus* & Quaranfil virus (QRFV) \\
\hline \multirow[t]{2}{*}{ Thogotovirus } & Dhori thogotovirus & Dhori virus (DHOV) \\
\hline & Thogoto thogotovirus* & Thogoto virus (THOV) \\
\hline
\end{tabular}

*Type species

IITaxon names are always italicized and always begin with a capital letter 
Table 7 ICTV-accepted taxonomy of the order Bunyavirales (Negarnaviricota: Polyploviricotina: Ellioviricetes) as of March 2020

\begin{tabular}{|c|c|c|}
\hline Genus & Species $^{\text {II }}$ & Virus $(\text { Abbreviation })^{\&}$ \\
\hline \multicolumn{3}{|c|}{ Family Arenaviridae } \\
\hline \multirow[t]{2}{*}{ Antennavirus } & Hairy antennavirus & Wēnlǐng frogfish arenavirus 2 (WlFAV-2) \\
\hline & Striated antennavirus* & Wēnlı̌ng frogfish arenavirus 1 (WlFAV-1) \\
\hline \multirow[t]{6}{*}{ Hartmanivirus } & Haartman hartmanivirus* & Haartman Institute snake virus 1 (HISV-1) \\
\hline & Muikkunen hartmanivirus & Dante Muikkunen virus 1 (DaMV-1) \\
\hline & Schoolhouse hartmanivirus & old schoolhouse virus $1(\mathrm{OScV}-1)$ \\
\hline & & old schoolhouse virus 2 (OScV-2) \\
\hline & Zurich hartmanivirus & veterinary pathology Zurich virus 1 (VPZV-1) \\
\hline & & veterinary pathology Zurich virus $2(\mathrm{VPZV}-2)$ \\
\hline \multirow[t]{41}{*}{ Mammarenavirus } & Allpahuayo mammarenavirus & Allpahuayo virus (ALLV) \\
\hline & Alxa mammarenavirus & Alxa virus (ALXV) \\
\hline & Argentinian mammarenavirus & Junín virus (JUNV) \\
\hline & Bear Canyon mammarenavirus & Bear Canyon virus (BCNV) \\
\hline & Brazilian mammarenavirus & Sabiá virus (SBAV) \\
\hline & Cali mammarenavirus & Pichindé virus (PICHV) \\
\hline & Chapare mammarenavirus & Chapare virus (CHAPV) \\
\hline & Chevrier mammarenavirus & Lìjiāng virus (LIJV) \\
\hline & Cupixi mammarenavirus & Cupixi virus (CUPXV) \\
\hline & Flexal mammarenavirus & Flexal virus (FLEV) \\
\hline & Gairo mammarenavirus & Gairo virus (GAIV) \\
\hline & Guanarito mammarenavirus & Guanarito virus (GTOV) \\
\hline & Ippy mammarenavirus & Ippy virus (IPPYV) \\
\hline & Lassa mammarenavirus & Lassa virus (LASV) \\
\hline & Latino mammarenavirus & Latino virus (LATV) \\
\hline & Loei River mammarenavirus & Loei River virus (LORV) \\
\hline & Lujo mammarenavirus & Lujo virus (LUJV) \\
\hline & Luna mammarenavirus & Luli virus (LULV) \\
\hline & & Luna virus (LUAV) \\
\hline & Lunk mammarenavirus & Lunk virus (LNKV) \\
\hline & Lymphocytic choriomeningitis mammarenavirus* & Dandenong virus (DANV) \\
\hline & & lymphocytic choriomeningitis virus (LCMV) \\
\hline & Machupo mammarenavirus & Machupo virus (MACV) \\
\hline & Mariental mammarenavirus & Mariental virus (MRLV) \\
\hline & Merino Walk mammarenavirus & Merino Walk virus (MRWV) \\
\hline & Mobala mammarenavirus & mobala virus (MOBV) \\
\hline & Mopeia mammarenavirus & Mopeia virus (MPOV) \\
\hline & & Morogoro virus (MORV) \\
\hline & Okahandja mammarenavirus & Okahandja virus (OKAV) \\
\hline & Oliveros mammarenavirus & Oliveros virus (OLVV) \\
\hline & Paraguayan mammarenavirus & Paraná virus (PRAV) \\
\hline & Planalto mammarenavirus & Aporé virus (APOV) \\
\hline & Pirital mammarenavirus & Pirital virus (PIRV) \\
\hline & Ryukyu mammarenavirus & Ryukyu virus (RYKV) \\
\hline & Serra do Navio mammarenavirus & Amaparí virus (AMAV) \\
\hline & Solwezi mammarenavirus & Solwezi virus (SOLV) \\
\hline & Souris mammarenavirus & souris virus (SOUV) \\
\hline & Tacaribe mammarenavirus & Tacaribe virus (TCRV) \\
\hline & Tamiami mammarenavirus & Tamiami virus (TMMV) \\
\hline & Wenzhou mammarenavirus & Wēnzhōu virus (WENV) \\
\hline & Whitewater Arroyo mammarenavirus & Big Brushy Tank virus (BBRTV) \\
\hline
\end{tabular}


Table 7 (continued)

\begin{tabular}{|c|c|c|}
\hline Genus & Species ${ }^{\mathbb{I}}$ & Virus (Abbreviation) ${ }^{\&}$ \\
\hline & & Catarina virus (CTNV) \\
\hline & & Skinner Tank virus (SKTV) \\
\hline & & Tonto Creek virus (TTCV) \\
\hline & & Whitewater Arroyo virus (WWAV) \\
\hline & Xapuri mammarenavirus & Xapuri virus (XAPV) \\
\hline \multirow[t]{8}{*}{ Reptarenavirus } & California reptarenavirus & CAS virus (CASV) \\
\hline & Giessen reptarenavirus & University of Giessen virus 1 (UGV-1) \\
\hline & & University of Giessen virus 2 (UGV-2) \\
\hline & & University of Giessen virus 3 (UGV-3) \\
\hline & Golden reptarenavirus* & Golden Gate virus (GOGV) \\
\hline & Ordinary reptarenavirus & tavallinen suomalainen mies virus 2 (TSMV-2) \\
\hline & Rotterdam reptarenavirus & ROUT virus (ROUTV) \\
\hline & & University of Helsinki virus 1 (UHV-1) \\
\hline \multicolumn{3}{|c|}{ Family Cruliviridae } \\
\hline Lincruvirus & Crustacean lincruvirus* & Wēnlǐng crustacean virus 9 (WlCV-9) \\
\hline \multicolumn{3}{|c|}{ Family Fimoviridae } \\
\hline \multirow[t]{11}{*}{ Emaravirus } & Actinidia chlorotic ringspot-associated emaravirus & Actinidia chlorotic ringspot-associated virus (AcCRaV) \\
\hline & Blackberry leaf mottle associated emaravirus & blackberry leaf mottle-associated virus (BLMaV) \\
\hline & $\begin{array}{l}\text { European mountain ash ringspot-associated emara- } \\
\text { virus* }\end{array}$ & $\begin{array}{l}\text { European mountain ash ringspot-associated virus } \\
\text { (EMARaV) }\end{array}$ \\
\hline & Fig mosaic emaravirus & fig mosaic virus (FMV) \\
\hline & High Plains wheat mosaic emaravirus & High Plains wheat mosaic virus (HPWMoV) \\
\hline & Pigeonpea sterility mosaic emaravirus 1 & pigeonpea sterility mosaic virus 1 (PPSMV-1) \\
\hline & Pigeonpea sterility mosaic emaravirus 2 & pigeonpea sterility mosaic virus 2 (PPSMV-2) \\
\hline & Pistacia emaravirus $B$ & pistacia virus $\mathrm{B}(\mathrm{PiVB})$ \\
\hline & Raspberry leaf blotch emaravirus & raspberry leaf blotch virus (RLBV) \\
\hline & Redbud yellow ringspot-associated emaravirus & redbud yellow ringspot-associated virus (RYRaV) \\
\hline & Rose rosette emaravirus & rose rosette virus (RRV) \\
\hline \multicolumn{3}{|c|}{ Family Hantaviridae } \\
\hline \multicolumn{3}{|c|}{ Subfamily Actantavirinae } \\
\hline \multirow[t]{3}{*}{ Actinovirus } & Batfish actinovirus* & Wēnlǐng minipizza batfish virus (WEMBV) \\
\hline & Goosefish actinovirus & Wēnlǐng yellow goosefish virus (WEYGV) \\
\hline & Spikefish actinovirus & Wēnlǐng red spikefish virus (WERSV) \\
\hline \multicolumn{3}{|c|}{ Subfamily Agantavirinae } \\
\hline Agnathovirus & Hagfish agnathovirus* & Wēnlǐng hagfish virus (WEHV) \\
\hline \multicolumn{3}{|c|}{ Subfamily Mammantavirinae } \\
\hline \multirow[t]{2}{*}{ Loanvirus } & Brno loanvirus & Brno virus (BRNV) \\
\hline & Longquan loanvirus* & Lóngquán virus (LQUV) \\
\hline \multirow[t]{3}{*}{ Mobatvirus } & Laibin mobatvirus & Láibīn virus (LAIV) \\
\hline & Nova mobatvirus* & Nova virus (NVAV) \\
\hline & Quezon mobatvirus & Quezon virus (QZNV) \\
\hline \multirow[t]{9}{*}{ Orthohantavirus } & Andes orthohantavirus & Andes virus (ANDV) \\
\hline & & Castelo dos Sonhos virus (CASV) \\
\hline & & Lechiguanas virus (LECV = LECHV) \\
\hline & & Orán virus (ORNV) \\
\hline & Asama orthohantavirus & Asama virus (ASAV) \\
\hline & Asikkala orthohantavirus & Asikkala virus (ASIV) \\
\hline & Bayou orthohantavirus & bayou virus (BAYV) \\
\hline & & Catacamas virus (CATV) \\
\hline & Black Creek Canal orthohantavirus & Black Creek Canal virus (BCCV) \\
\hline
\end{tabular}


Table 7 (continued)

\begin{tabular}{|c|c|c|}
\hline Genus & Species ${ }^{\mathbb{I I}}$ & Virus (Abbreviation) ${ }^{\&}$ \\
\hline & Bowe orthohantavirus & Bowé virus (BOWV) \\
\hline & Bruges orthohantavirus & Bruges virus (BRGV) \\
\hline & Cano Delgadito orthohantavirus & Caño Delgadito virus (CADV) \\
\hline & \multirow[t]{2}{*}{ Cao Bang orthohantavirus } & Cao Bằng virus (CBNV) \\
\hline & & Liánghé virus (LHEV) \\
\hline & Choclo orthohantavirus & Choclo virus (CHOV) \\
\hline & Dabieshan orthohantavirus & Dàbiéshān virus (DBSV) \\
\hline & \multirow[t]{4}{*}{ Dobrava-Belgrade orthohantavirus } & Dobrava virus (DOBV) \\
\hline & & Kurkino virus (KURV) \\
\hline & & Saaremaa virus (SAAV) \\
\hline & & Sochi virus (SOCV) \\
\hline & \multirow[t]{3}{*}{ El Moro Canyon orthohantavirus } & Carrizal virus (CARV) \\
\hline & & El Moro Canyon virus (ELMCV) \\
\hline & & Huitzilac virus (HUIV) \\
\hline & Fugong orthohantavirus & Fúgòng virus (FUGV) \\
\hline & Fusong orthohantavirus & Fǔsōng virus (FUSV) \\
\hline & \multirow[t]{3}{*}{ Hantaan orthohantavirus* } & Amur virus (AMRV) \\
\hline & & Hantaan virus (HTNV) \\
\hline & & Soochong virus (SOOV) \\
\hline & Jeju orthohantavirus & Jeju virus (JJUV) \\
\hline & Kenkeme orthohantavirus & Kenkeme virus (KKMV) \\
\hline & \multirow[t]{2}{*}{ Khabarovsk orthohantavirus } & Khabarovsk virus (KHAV) \\
\hline & & Topografov virus (TOPV) \\
\hline & \multirow[t]{3}{*}{ Laguna Negra orthohantavirus } & Laguna Negra virus (LANV) \\
\hline & & Maripa virus (MARV) \\
\hline & & Rio Mamoré virus (RIOMV) \\
\hline & Luxi orthohantavirus & Lúxī virus (LUXV) \\
\hline & Maporal orthohantavirus & Maporal virus (MAPV) \\
\hline & Montano orthohantavirus & Montaño virus (MTNV) \\
\hline & Necocli orthohantavirus & Necoclí virus (NECV) \\
\hline & Oxbow orthohantavirus & Oxbow virus (OXBV) \\
\hline & Prospect Hill orthohantavirus & Prospect Hill virus (PHV) \\
\hline & \multirow[t]{3}{*}{ Puumala orthohantavirus } & Hokkaido virus (HOKV) \\
\hline & & Muju virus (MUJV) \\
\hline & & Puumala virus (PUUV) \\
\hline & Rockport orthohantavirus & Rockport virus (RKPV) \\
\hline & Sangassou orthohantavirus & Sangassou virus (SANGV) \\
\hline & Seewis orthohantavirus & Seewis virus (SWSV) \\
\hline & \multirow[t]{2}{*}{ Seoul orthohantavirus } & gōu virus (GOUV) \\
\hline & & Seoul virus (SEOV) \\
\hline & \multirow[t]{2}{*}{ Sin Nombre orthohantavirus } & New York virus (NYV) \\
\hline & & Sin Nombre virus (SNV) \\
\hline & \multirow[t]{3}{*}{ Thailand orthohantavirus } & Anjozorobe virus (ANJZV) \\
\hline & & Serang virus (SERV) \\
\hline & & Thailand virus (THAIV) \\
\hline & Tigray orthohantavirus & Tigray virus (TIGV) \\
\hline & \multirow[t]{2}{*}{ Tula orthohantavirus } & Adler virus (ADLV) \\
\hline & & Tula virus (TULV) \\
\hline & Yakeshi orthohantavirus & Yákèshí virus (YKSV) \\
\hline Thottimvirus & Imjin thottimvirus & Imjin virus (MJNV) \\
\hline
\end{tabular}


Table 7 (continued)

\begin{tabular}{|c|c|c|}
\hline Genus & Species ${ }^{\text {II }}$ & Virus (Abbreviation) ${ }^{\&}$ \\
\hline & Thottapalayam thottimvirus* & Thottapalayam virus (TPMV) \\
\hline \multicolumn{3}{|c|}{ Subfamily Repantavirinae } \\
\hline Reptillovirus & Gecko reptillovirus* & Hăinán oriental leaf-toed gecko virus (HOLGV) \\
\hline \multicolumn{3}{|c|}{ Family Leishbuviridae } \\
\hline Shilevirus & Leptomonas shilevirus* & $\begin{array}{l}\text { Leptomonas moramango virus } \\
\text { (LEPMV) }\end{array}$ \\
\hline \multicolumn{3}{|c|}{ Family Mypoviridae } \\
\hline Hubavirus & Myriapod hubavirus* & Húběi myriapoda virus 5 (HbMV-5) \\
\hline \multicolumn{3}{|c|}{ Family Nairoviridae } \\
\hline \multirow[t]{41}{*}{ Orthonairovirus } & Artashat orthonairovirus & Artashat virus (ARTSV) \\
\hline & Chim orthonairovirus & Chim virus (CHIMV) \\
\hline & Crimean-Congo hemorrhagic fever orthonairovirus & Crimean-Congo hemorrhagic fever virus (CCHFV) \\
\hline & Dera Ghazi Khan orthonairovirus & Abu Hammad virus (AHV) \\
\hline & & Abu Mina virus (AMV) \\
\hline & & Dera Ghazi Khan virus (DGKV) \\
\hline & & Sapphire II virus (SAPV) \\
\hline & Dugbe orthonairovirus* & Dugbe virus (DUGV) \\
\hline & & kupe virus (KUPEV) \\
\hline & Estero Real orthonairovirus & Estero Real virus (ERV) \\
\hline & Hazara orthonairovirus & Hazara virus (HAZV) \\
\hline & & Tofla virus (TFLV) \\
\hline & Hughes orthonairovirus & Caspiy virus (CASV) \\
\hline & & Farallon virus (FARV) \\
\hline & & Great Saltee virus (GRSV) \\
\hline & & Hughes virus (HUGV) \\
\hline & & Punta Salinas virus (PSV) \\
\hline & & Raza virus (RAZAV) \\
\hline & & Soldado virus (SOLV) \\
\hline & & Zirqa virus (ZIRV) \\
\hline & Kasokero orthonairovirus & Kasokero virus (KASV = KASOV) \\
\hline & & Leopards Hill virus (LPHV) \\
\hline & & Yogue virus (YOGV) \\
\hline & Keterah orthonairovirus & Gossas virus (GOSV) \\
\hline & & Issyk-kul virus (ISKV) \\
\hline & & Keterah virus (KTRV) \\
\hline & & Uzun-Agach virus (UZAV) \\
\hline & Nairobi sheep disease orthonairovirus & Nairobi sheep disease virus (NSDV) \\
\hline & Qalyub orthonairovirus & Bandia virus (BDAV) \\
\hline & & Geran virus (GERV) \\
\hline & & Qalyub virus (QYBV) \\
\hline & Sakhalin orthonairovirus & Avalon virus (AVAV) \\
\hline & & Clo Mor virus (CMV = CLMV) \\
\hline & & Sakhalin virus (SAKV) \\
\hline & & Taggert virus (TAGV) \\
\hline & & Tillamook virus (TILLV) \\
\hline & Tamdy orthonairovirus & Burana virus (BURV) \\
\hline & & Huángpí tick virus 1 (HpTV-1) \\
\hline & & Tăchéng tick virus 1 (TcTV-1) \\
\hline & & Tamdy virus (TAMV) \\
\hline & & Wēnzhōu tick virus (WzTV) \\
\hline
\end{tabular}


Table 7 (continued)

\begin{tabular}{|c|c|c|}
\hline Genus & Species ${ }^{\mathbb{I}}$ & Virus (Abbreviation) ${ }^{\&}$ \\
\hline & Thiafora orthonairovirus & Erve virus (ERVEV) \\
\hline & & Thiafora virus (TFAV) \\
\hline Shaspivirus & Spider shaspivirus* & Shāyáng spider virus 1 (SySV-1) \\
\hline Striwavirus & Strider striwavirus* & Sānxiá water strider virus 1 (SxWSV-1) \\
\hline \multicolumn{3}{|c|}{ Family Peribunyaviridae } \\
\hline \multirow[t]{3}{*}{ Herbevirus } & Herbert herbevirus* & Herbert virus (HEBV) \\
\hline & Kibale herbevirus & Kibale virus (KIBV) \\
\hline & Tai herbevirus & Taï virus (TAIV) \\
\hline \multirow[t]{42}{*}{ Orthobunyavirus } & Acara orthobunyavirus & Acará virus (ACAV) \\
\hline & & Moriche virus (MORV) \\
\hline & Aino orthobunyavirus & Aino virus (AINOV) \\
\hline & Akabane orthobunyavirus & Akabane virus (AKAV) \\
\hline & & Tinaroo virus (TINV) \\
\hline & & Yaba-7 virus (Y7V) \\
\hline & Alajuela orthobunyavirus & Alajuela virus (ALJV) \\
\hline & & San Juan virus (SJV) \\
\hline & Anadyr orthobunyavirus & Anadyr virus (ANADV) \\
\hline & Anhembi orthobunyavirus & Anhembi virus (AMBV) \\
\hline & Anopheles A orthobunyavirus & Anopheles A virus (ANAV) \\
\hline & & Arumateua virus $(\mathrm{ARTV}=\mathrm{ARMTV})$ \\
\hline & & Caraipé virus (CPEV = CRPV) \\
\hline & & Las Maloyas virus (LMV) \\
\hline & & Lukuni virus (LUKV) \\
\hline & & Trombetas virus (TRMV) \\
\hline & & Tucuruí virus (TUCV = TUCRV) \\
\hline & Anopheles B orthobunyavirus & Anopheles B virus (ANBV) \\
\hline & & Boracéia virus (BORV) \\
\hline & Bakau orthobunyavirus & Bakau virus (BAKV) \\
\hline & & Ketapang virus (KETV) \\
\hline & & Nola virus (NOLAV) \\
\hline & & Tanjong Rabok virus (TRV) \\
\hline & & Telok Forest virus (TFV) \\
\hline & Batai orthobunyavirus & Batai virus (BATV) \\
\hline & Batama orthobunyavirus & Batama virus (BMAV) \\
\hline & Bellavista orthobunyavirus & Bellavista virus (BELLV) \\
\hline & Benevides orthobunyavirus & Benevides virus (BVSV $=$ BENV) \\
\hline & Bertioga orthobunyavirus & Bertioga virus (BERV) \\
\hline & & Cananéia virus (CNAV) \\
\hline & & Guaratuba virus (GTBV) \\
\hline & & Itimirim virus (ITIV) \\
\hline & & Mirim virus (MIRV) \\
\hline & Bimiti orthobunyavirus & bimiti virus (BIMV) \\
\hline & Birao orthobunyavirus & Birao virus (BIRV) \\
\hline & Botambi orthobunyavirus & Botambi virus (BOTV) \\
\hline & Bozo orthobunyavirus & Bozo virus (BOZOV) \\
\hline & Bunyamwera orthobunyavirus* & Bunyamwera virus (BUNV) \\
\hline & & Germiston virus (GERV) \\
\hline & & Lokern virus (LOKV) \\
\hline & & Mboké virus (MBOV) \\
\hline & & Ngari virus (NRIV) \\
\hline
\end{tabular}


Table 7 (continued)

\begin{tabular}{|c|c|c|}
\hline Genus & Species $^{\mathrm{I}}$ & Virus (Abbreviation) $)^{\&}$ \\
\hline & \multirow{8}{*}{ Bushbush orthobunyavirus } & Northway virus (NORV) \\
\hline & & Santa Rosa virus (SARV) \\
\hline & & Shokwe virus (SHOV) \\
\hline & & Stanfield virus (STAV) \\
\hline & & Xingu virus (XINV) \\
\hline & & Benfica virus (BENV = BNFV) \\
\hline & & Bushbush virus (BSBV) \\
\hline & & Juan Díaz virus (JDV) \\
\hline & Buttonwillow orthobunyavirus & Buttonwillow virus (BUTV) \\
\hline & \multirow[t]{2}{*}{ Bwamba orthobunyavirus } & Bwamba virus (BWAV) \\
\hline & & Pongola virus (PGAV) \\
\hline & \multirow[t]{3}{*}{ Cache Valley orthobunyavirus } & Cache Valley virus (CVV) \\
\hline & & Cholul virus (CHLV) \\
\hline & & Tlacotalpan virus (TLAV) \\
\hline & Cachoeira Porteira orthobunyavirus & Cachoeira Porteira virus (CPOV) \\
\hline & \multirow[t]{2}{*}{ California encephalitis orthobunyavirus } & California encephalitis virus (CEV) \\
\hline & & Morro Bay virus (MBV) \\
\hline & Capim orthobunyavirus & Capim virus (CAPV) \\
\hline & \multirow[t]{7}{*}{ Caraparu orthobunyavirus } & Apeú virus (APEUV) \\
\hline & & Bruconha virus (BRUV) \\
\hline & & Caraparú virus (CARV) \\
\hline & & El Huayo virus (EHUV) \\
\hline & & Itaya virus (ITYV) \\
\hline & & Ossa virus (OSSAV) \\
\hline & & Vinces virus (VINV) \\
\hline & \multirow[t]{2}{*}{ Cat Que orthobunyavirus } & Cát Quế virus (CQV) \\
\hline & & Oya virus (OYAV) \\
\hline & Catu orthobunyavirus & Catú virus (CATUV) \\
\hline & Enseada orthobunyavirus & Enseada virus (ENSV) \\
\hline & Faceys paddock orthobunyavirus & Facey's paddock virus (FPV) \\
\hline & Fort Sherman orthobunyavirus & Fort Sherman virus (FSV) \\
\hline & \multirow[t]{5}{*}{ Gamboa orthobunyavirus } & Brus Laguna virus (BLAV) \\
\hline & & Calchaquí virus (CQIV) \\
\hline & & Gamboa virus (GAMV) \\
\hline & & Pueblo Viejo virus (PVV) \\
\hline & & Soberanía virus (SOBV) \\
\hline & Guajara orthobunyavirus & Guajará virus (GJAV) \\
\hline & \multirow[t]{4}{*}{ Guama orthobunyavirus } & Ananindeua virus (ANUV) \\
\hline & & Guamá virus (GMAV) \\
\hline & & Mahogany Hammock virus (MHV) \\
\hline & & Moju virus (MOJUV) \\
\hline & Guaroa orthobunyavirus & Guaroa virus (GROV) \\
\hline & Iaco orthobunyavirus & Iaco virus (IACOV) \\
\hline & Ilesha orthobunyavirus & Ilesha virus (ILEV) \\
\hline & Ingwavuma orthobunyavirus & Ingwavuma virus (INGV) \\
\hline & \multirow[t]{4}{*}{ Jamestown Canyon orthobunyavirus } & Inkoo virus (INKV) \\
\hline & & Jamestown Canyon virus (JCV) \\
\hline & & Jerry Slough virus (JSV) \\
\hline & & South River virus (SORV) \\
\hline & Jatobal orthobunyavirus & Jatobal virus (JATV) \\
\hline
\end{tabular}


Table 7 (continued)

\begin{tabular}{|c|c|c|}
\hline Genus & Species ${ }^{\mathbb{I I}}$ & Virus (Abbreviation) ${ }^{\&}$ \\
\hline & Kaeng Khoi orthobunyavirus & Kaeng Khoi virus (KKV) \\
\hline & Kairi orthobunyavirus & Kairi virus (KRIV) \\
\hline & Keystone orthobunyavirus & Keystone virus (KEYV) \\
\hline & Koongol orthobunyavirus & koongol virus (KOOV) \\
\hline & & wongal virus (WONV) \\
\hline & La Crosse orthobunyavirus & La Crosse virus (LACV) \\
\hline & Leanyer orthobunyavirus & Leanyer virus (LEAV) \\
\hline & Lumbo orthobunyavirus & Lumbo virus (LUMV) \\
\hline & Macaua orthobunyavirus & Macauã virus (MCAV) \\
\hline & Madrid orthobunyavirus & Madrid virus (MADV) \\
\hline & Maguari orthobunyavirus & Maguari virus (MAGV) \\
\hline & & Playas virus (PLAV) \\
\hline & Main Drain orthobunyavirus & Main Drain virus (MDV) \\
\hline & Manzanilla orthobunyavirus & Manzanilla virus (MANV) \\
\hline & & Inini virus (INIV) \\
\hline & Marituba orthobunyavirus & Gumbo Limbo virus (GLV) \\
\hline & & Marituba virus (MTBV) \\
\hline & & Murutucú virus (MURV) \\
\hline & & Nepuyo virus (NEPV) \\
\hline & & Restan virus (RESV) \\
\hline & & Zungarococha virus (ZUNV) \\
\hline & Melao orthobunyavirus & Melao virus (MELV) \\
\hline & Mermet orthobunyavirus & Mermet virus (MERV) \\
\hline & Minatitlan orthobunyavirus & Minatitlán virus (MNTV) \\
\hline & & Palestina virus (PLSV) \\
\hline & MPoko orthobunyavirus & M'Poko virus (MPOV) \\
\hline & & Yaba-1 virus $(\mathrm{Y} 1 \mathrm{~V})$ \\
\hline & Nyando orthobunyavirus & Eretmapodites virus (ERETV) \\
\hline & & Mojuí dos Campos virus (MDCV) \\
\hline & & Nyando virus (NDV) \\
\hline & Olifantsvlei orthobunyavirus & Bobia virus (BIAV) \\
\hline & & Dabakala virus (DABV) \\
\hline & & Olifantsvlei virus (OLIV) \\
\hline & & Oubi virus (OUBIV) \\
\hline & Oriboca orthobunyavirus & Itaquí virus (ITQV) \\
\hline & & Oriboca virus (ORIV) \\
\hline & Oropouche orthobunyavirus & Iquitos virus (IQTV) $^{\mathrm{d}}$ \\
\hline & & Madre de Dios virus (MDDV) \\
\hline & & Oropouche virus (OROV) \\
\hline & & Perdões virus (PDEV) \\
\hline & & Pintupo virus (PINTV) \\
\hline & Patois orthobunyavirus & Abras virus (ABRV) \\
\hline & & Babahoya virus (BABV) \\
\hline & & Pahayokee virus (PAHV) \\
\hline & & Patois virus (PATV) \\
\hline & & Shark River virus (SRV) \\
\hline & Peaton orthobunyavirus & Peaton virus (PEAV) \\
\hline & Potosi orthobunyavirus & Potosi virus (POTV) \\
\hline & Sabo orthobunyavirus & Sabo virus (SABOV) \\
\hline & San Angelo orthobunyavirus & San Angelo virus (SAV) \\
\hline
\end{tabular}


Table 7 (continued)

\begin{tabular}{|c|c|c|}
\hline Genus & Species ${ }^{\mathbb{I}}$ & Virus (Abbreviation) ${ }^{\&}$ \\
\hline & Sango orthobunyavirus & Sango virus (SANV) \\
\hline & Schmallenberg orthobunyavirus & Douglas virus (DOUV) \\
\hline & & Sathuperi virus (SATV) \\
\hline & & Schmallenberg virus (SBV) \\
\hline & & Shamonda virus (SHAV) \\
\hline & Serra do Navio orthobunyavirus & Serra do Navio virus (SDNV) \\
\hline & Shuni orthobunyavirus & Kaikalur virus (KAIV) \\
\hline & & Shuni virus (SHUV) \\
\hline & Simbu orthobunyavirus & Para virus (PARAV) \\
\hline & & Simbu virus (SIMV) \\
\hline & Snowshoe hare orthobunyavirus & Khatanga virus (KHATV) ${ }^{9}$ \\
\hline & & snowshoe hare virus (SSHV) \\
\hline & Sororoca orthobunyavirus & Sororoca virus (SORV) \\
\hline & Tacaiuma orthobunyavirus & CoAr 1071 virus (CA1071V) \\
\hline & & CoAr 3627 virus (CA3626V) \\
\hline & & Tacaiuma virus (TCMV) \\
\hline & & Virgin River virus (VRV) \\
\hline & Tahyna orthobunyavirus & Ťahyňa virus (TAHV) \\
\hline & Tataguine orthobunyavirus & Tataguine virus (TATV) \\
\hline & Tensaw orthobunyavirus & Tensaw virus (TENV) \\
\hline & Tete orthobunyavirus & Bahig virus (BAHV) \\
\hline & & Matruh virus (MTRV) \\
\hline & & Tete virus (TETEV) \\
\hline & & Tsuruse virus (TSUV) \\
\hline & & Weldona virus (WELV) \\
\hline & Thimiri orthobunyavirus & Thimiri virus (THIV) \\
\hline & Timboteua orthobunyavirus & Timboteua virus (TBTV) \\
\hline & Trivittatus orthobunyavirus & Achiote virus (ACHOV) \\
\hline & & Trivittatus virus (TVTV) \\
\hline & Turlock orthobunyavirus & Lednice virus (LEDV) \\
\hline & & Turlock virus (TURV) \\
\hline & & Umbre virus (UMBV) \\
\hline & Utinga orthobunyavirus & Utinga virus (UTIV) \\
\hline & Witwatersrand orthobunyavirus & Witwatersrand virus (WITV) \\
\hline & Wolkberg orthobunyavirus & Wolkberg virus (WBV) \\
\hline & Wyeomyia orthobunyavirus & Rio Pracupi virus \\
\hline & & Taiassui virus (TAIAV) \\
\hline & & Tucunduba virus (TUCV) \\
\hline & & Wyeomyia virus (WYOV) \\
\hline & Zegla orthobunyavirus & Zegla virus (ZEGV) \\
\hline \multirow[t]{5}{*}{ Pacuvirus } & Caimito pacuvirus & Caimito virus (CAIV) \\
\hline & Chilibre pacuvirus & Chilibre virus (CHIV) \\
\hline & Pacui pacuvirus* & Pacui virus (PACV) \\
\hline & Rio Preto da Eva pacuvirus & Rio Preto da Eva virus (RPEV) \\
\hline & Tapirape pacuvirus & Tapirapé virus (TAPV) \\
\hline Shangavirus & Insect shangavirus* & Shuāngào insect virus 1 (SgIV-1) \\
\hline \multicolumn{3}{|c|}{ Family Phasmaviridae } \\
\hline Feravirus & Ferak feravirus* & Ferak virus (FRKV) \\
\hline Jonvirus & Jonchet jonvirus* & jonchet virus (JONV) \\
\hline Orthophasmavirus & Anopheles orthophasmavirus & Anopheles triannulatus orthophasmavirus (AtOPV) \\
\hline
\end{tabular}


Table 7 (continued)

\begin{tabular}{|c|c|c|}
\hline Genus & Species ${ }^{\mathrm{II}}$ & Virus (Abbreviation) $)^{\&}$ \\
\hline & Culex orthophasmavirus & Culex orthophasmavirus (CPLV) \\
\hline & Ganda orthophasmavirus & Ganda orthophasmavirus (GBEEV) \\
\hline & Kigluaik phantom orthophasmavirus* & Kigluaik phantom virus (KIGV) \\
\hline & Odonate orthophasmavirus & Odonate orthophasmavirus (HbOV-8) \\
\hline & Qingling orthophasmavirus & Qingling orthophasmavirus (HbOV-9) \\
\hline & Wuchang cockroach orthophasmavirus 1 & Wǔchāng cockroach virus 1 (WcCV-1) \\
\hline & Wuhan mosquito orthophasmavirus 1 & Wǔhàn mosquito virus 1 (WhMV-1) \\
\hline & Wuhan mosquito orthophasmavirus 2 & Wǔhàn mosquito virus 2 (WhMV-2) \\
\hline Sawastrivirus & Sanxia sawastrivirus* & Sānxiá water strider virus 2 (SxWSV-2) \\
\hline Wuhivirus & Insect wuhivirus* & Wǔhàn insect virus 2 (WhIV-2) \\
\hline \multicolumn{3}{|c|}{ Family Phenuiviridae } \\
\hline \multirow[t]{7}{*}{ Bandavirus } & Bhanja bandavirus & Bhanja virus (BHAV) \\
\hline & Dabie bandavirus* & $\begin{array}{l}\text { severe fever with thrombocytopenia syndrome virus } \\
\text { (SFTSV) }\end{array}$ \\
\hline & Guertu bandavirus & Guertu virus (GTV) \\
\hline & Heartland bandavirus & Heartland virus (HRTV) \\
\hline & Hunter Island bandavirus & Hunter Island virus (HUIV) \\
\hline & Kismaayo bandavirus & Kismaayo virus (KISV) \\
\hline & Lone Star bandavirus ${ }^{1}$ & lone star virus (LSV) \\
\hline Beidivirus & Dipteran beidivirus* & Húběi diptera virus 3 (HbDV-3) \\
\hline \multirow[t]{2}{*}{ Coguvirus } & Citrus coguvirus $*$ & citrus concave gum-associated virus (CCGaV) \\
\hline & Coguvirus eburi & citrus virus $\mathrm{A}(\mathrm{CiV}-\mathrm{A})$ \\
\hline Entovirus & Entoleuca entovirus* & Entoleuca phenui-like virus 1 (EnPLV-1) \\
\hline \multirow[t]{3}{*}{ Goukovirus } & Cumuto goukovirus & Cumuto virus (CUMV) \\
\hline & Gouleako goukovirus* & Gouléako virus (GOLV) \\
\hline & Yichang insect goukovirus & Yíchāng insect virus (YcIV) \\
\hline Horwuvirus & Horsefly horwuvirus* & Wǔhàn horsefly virus (WhHV) \\
\hline Hudivirus & Dipteran hudivirus* & Húběi diptera virus 4 (HbDV-4) \\
\hline Hudovirus & Lepidopteran hudovirus* & Húběi lepidoptera virus 1 (HbLV-1) \\
\hline \multirow[t]{3}{*}{ Ixovirus } & Blackleg ixovirus* & blacklegged tick virus 1 (BLTV-1) \\
\hline & Norway ixovirus & Fairhair virus (FHAV) \\
\hline & Scapularis ixovirus & blacklegged tick virus 3 (BLTV-3) \\
\hline Laulavirus & Laurel Lake laulavirus* & Laurel Lake virus (LLV) \\
\hline Lentinuvirus & Lentinula lentinuvirus* & $\begin{array}{l}\text { Lentinula edodes negative-strand RNA virus } 2 \text { (LeN- } \\
\text { SRV-2) }\end{array}$ \\
\hline Mobuvirus & Mothra mobuvirus* & Mothra virus (MTHV) \\
\hline \multirow[t]{5}{*}{ Phasivirus } & Badu phasivirus* & Badu virus (BADUV) \\
\hline & Dipteran phasivirus & Húběi diptera virus 5 (HbDV-5) \\
\hline & Fly phasivirus & Wǔhàn fly virus 1 (WhFV-1) \\
\hline & Phasi Charoen-like phasivirus & Phasi Chaeron-like virus (PCLV) \\
\hline & Wutai mosquito phasivirus & Wǔtái mosquito virus (WtMV) \\
\hline \multirow[t]{9}{*}{ Phlebovirus } & Adana phlebovirus & Adana virus (ADAV) \\
\hline & Aguacate phlebovirus & Aguacate virus (AGUV) \\
\hline & Alcube phlebovirus & Alcube virus (ACBV) \\
\hline & Alenquer phlebovirus & Alenquer virus (ALEV) \\
\hline & Ambe phlebovirus & Ambe virus (ABEV) \\
\hline & Anhanga phlebovirus & Anhangá virus (ANHV) \\
\hline & Arumowot phlebovirus & Arumowot virus (AMTV) \\
\hline & Buenaventura phlebovirus & Buenaventura virus (BUEV) \\
\hline & Bujaru phlebovirus & Bujaru virus (BUJV) \\
\hline
\end{tabular}


Table 7 (continued)

\begin{tabular}{|c|c|c|}
\hline Genus & Species $^{\text {II }}$ & Virus (Abbreviation) $)^{\&}$ \\
\hline & Cacao phlebovirus & Cacao virus (CACV) \\
\hline & Campana phlebovirus & Campana virus (CMAV) \\
\hline & Candiru phlebovirus & Ariquemes virus (ARQV) \\
\hline & & Candirú virus (CDUV) \\
\hline & & Jacundá virus (JCNV) \\
\hline & & Morumbi virus (MR(M)BV) \\
\hline & & Mucura virus (MCRV/MRAV) \\
\hline & & Serra Norte virus (SRNV) \\
\hline & Chagres phlebovirus & Chagres virus (CHGV) \\
\hline & Cocle phlebovirus & Coclé virus (CCLV) \\
\hline & Dashli phlebovirus & Dāshlī virus (DASV) \\
\hline & Durania phlebovirus & Durania virus (DRNV) \\
\hline & Echarate phlebovirus & Echarate virus (ECHV) \\
\hline & Gabek phlebovirus & Gabek forest virus (GFV) \\
\hline & Gordil phlebovirus & Gordil virus (GORV) \\
\hline & Icoaraci phlebovirus & Icoaraci virus (ICOV) \\
\hline & Itaituba phlebovirus & Itaituba virus (ITAV) \\
\hline & Itaporanga phlebovirus & Itaporanga virus (ITPV) \\
\hline & Ixcanal phlebovirus & Ixcanal virus (IXCV) \\
\hline & Karimabad phlebovirus & Karimabad virus (KARV) \\
\hline & La Gloria phlebovirus & La Gloria virus (LAGV) \\
\hline & Lara phlebovirus & Rio Claro virus (RICV) \\
\hline & Leticia phlebovirus & Leticia virus (LTCV) \\
\hline & Maldonado phlebovirus & Maldonado virus (MLOV) \\
\hline & Mariquita phlebovirus & Mariquita virus (MRQV) \\
\hline & Massilia phlebovirus & Massilia virus (MASV) \\
\hline & Medjerda phlebovirus & Medjerda Valley virus (MVV) \\
\hline & Mona Grita phlebovirus & Mona Grita virus (MOGV) \\
\hline & Mukawa phlebovirus & Mukawa virus (MKWV) \\
\hline & Munguba phlebovirus & Munguba virus (MUNV) \\
\hline & Naples phlebovirus & Arrábida virus (ARRV) \\
\hline & & Balkan virus (BALKV) \\
\hline & & Fermo virus (FERV) \\
\hline & & Granada virus (GRV = GRAV) \\
\hline & & Saddaguia virus (SADV) \\
\hline & & sandfly fever Naples virus (SFNV) \\
\hline & Nique phlebovirus & Nique virus (NIQV) \\
\hline & Ntepes phlebovirus & Ntepes virus (NTPV) \\
\hline & Odrenisrou phlebovirus & Odrénisrou virus (ODRV) \\
\hline & Oriximina phlebovirus & Oriximiná virus (ORXV) \\
\hline & Pena Blanca phlebovirus & Peña Blanca virus (PEBV) \\
\hline & Punique phlebovirus & Punique virus (PUNV) \\
\hline & Punta Toro phlebovirus & Buenaventura virus (BUEV) \\
\hline & & Capira virus (CAPIV) \\
\hline & & Punta Toro virus (PTV) \\
\hline & Rift Valley fever phlebovirus* & Rift Valley fever virus (RVFV) \\
\hline & Rio Grande phlebovirus & Rio Grande virus (RGV) \\
\hline & Saint Floris phlebovirus & Saint-Floris virus (SAFV) \\
\hline & Salanga phlebovirus & Salanga virus (SLGV) \\
\hline & Salehabad phlebovirus & Adria virus (ADRV) \\
\hline
\end{tabular}


Table 7 (continued)

\begin{tabular}{|c|c|c|}
\hline Genus & Species ${ }^{\mathbb{I}}$ & Virus (Abbreviation) ${ }^{\&}$ \\
\hline & & Arbia virus (ARBV) \\
\hline & & Bregalaka virus (BREV) \\
\hline & & Olbia virus (OLBV) \\
\hline & & Salehabad virus (SALV) \\
\hline & & Zaba virus (ZABAV) \\
\hline & Salobo phlabovirus $[\mathrm{sic}]^{2}$ & Salobo virus (SLBOV) \\
\hline & Sicilian phlebovirus & sandfly fever Sicilian virus (SFSV) \\
\hline & Tapara phlebovirus & Tapará virus (TPRV) \\
\hline & Tehran phlebovirus & Tehran virus (THEV) \\
\hline & Tico phebovirus $[\mathrm{sic}]^{3}$ & Tico virus (TICV) \\
\hline & Toros phlebovirus & Toros virus (TORV) \\
\hline & Toscana phlebovirus & Toscana virus (TOSV) \\
\hline & Tres Almendras phlebovirus & Tres Almendras virus (TRAV) \\
\hline & Turuna phlebovirus & Turuna virus (TUAV) \\
\hline & Uriurana phlebovirus & Uriurana virus (URIV) \\
\hline & Urucuri phlebovirus & Urucuri virus (URUV) \\
\hline & Viola phlebovirus & viola virus (VIOV) \\
\hline & Zerdali phlebovirus & Zerdali virus (ZERV) \\
\hline Pidchovirus & Pidgey pidchovirus* & Pidgey virus (PGYV) \\
\hline \multirow[t]{2}{*}{ Rubodvirus } & Apple rubodvirus $1 *$ & apple rubbery wood virus 1 (ARWV-1) \\
\hline & Apple rubodvirus 2 & apple rubbery wood virus 2 (ARWV-2) \\
\hline \multirow[t]{8}{*}{ Tenuivirus } & Echinochloa hoja blanca tenuivirus & Echinochloa hoja blanca virus (EHBV) \\
\hline & Iranian wheat stripe tenuivirus & Iranian wheat stripe virus (IWSV) \\
\hline & Maize stripe tenuivirus & maize stripe virus $(\mathrm{MStV}=\mathrm{MSpV})$ \\
\hline & Melon tenuivirus & melon chlorotic spot virus (MeCSV) \\
\hline & Rice grassy stunt tenuivirus & rice grassy stunt virus (RGSV) \\
\hline & Rice hoja blanca tenuivirus & rice hoja blanca virus (RHBV) \\
\hline & Rice stripe tenuivirus* & rice stripe virus $(\mathrm{RSV}=\mathrm{RStV})$ \\
\hline & Urochloa hoja blanca tenuivirus & Urochloa hoja blanca virus (UHBV) \\
\hline \multirow[t]{21}{*}{ Uukuvirus } & American dog uukuvirus & American dog tick virus (ADAV) \\
\hline & Dabieshan uukuvirus & Dàbiéshān tick virus (DBSH) \\
\hline & Grand Arbaud uukuvirus & Grand Arbaud virus (GAV) \\
\hline & Huangpi uukuvirus & Huángpí tick virus 2 (HpTV-2) \\
\hline & Kabuto mountain uukuvirus & Kabuto mountain virus (KAMV) \\
\hline & Kaisodi uukuvirus & Kaisodi virus (KASDV) \\
\hline & Lihan uukuvirus & Lǐhán tick virus (LITV) \\
\hline & Manawa uukuvirus & Manawa virus (MWAV) \\
\hline & Murre uukuvirus & murre virus (MURV) \\
\hline & Pacific coast uukuvirus & Pacific coast tick virus (PACV) \\
\hline & Precarious Point uukuvirus & Precarious Point virus (PPV) \\
\hline & Rukutama uukuvirus & Rukutama virus (RUKV) \\
\hline & Schmid uukuvirus & Nile Warbler virus (NIWV) \\
\hline & Silverwater uukuvirus & Silverwater virus (SILV) \\
\hline & Tacheng uukuvirus & Tăchéng tick virus 2 (TCGV) \\
\hline & Uukuniemi uukuvirus* & Chizé virus (CHZV) \\
\hline & & Fin V 707 virus (FINV) \\
\hline & & Oceanside virus $(\mathrm{OCV}=\mathrm{OCEV})$ \\
\hline & & Pontevès virus (PTVV) \\
\hline & & St. Abbs Head virus (SAHV) \\
\hline & & Uukuniemi virus (UUKV) \\
\hline
\end{tabular}


Table 7 (continued)

\begin{tabular}{|c|c|c|}
\hline Genus & Species $^{\text {II }}$ & Virus $(\text { Abbreviation })^{\&}$ \\
\hline & Yongjia uukuvirus & Yǒngjiā tick virus (YONV) \\
\hline & Zaliv Terpeniya uukuvirus & Zaliv Terpeniya virus (ZTV) \\
\hline Wenrivirus & Shrimp wenrivirus* & Wēnzhōu shrimp virus 1 (WzSV-1) \\
\hline \multicolumn{3}{|c|}{ Family Tospoviridae } \\
\hline \multirow[t]{26}{*}{ Orthotospovirus } & Alstroemeria necrotic streak orthotospovirus & Alstroemeria necrotic streak virus (ANSV) \\
\hline & Alstroemeria yellow spot orthotospovirus & Alstroemeria yellow spot virus (AYSV) \\
\hline & Bean necrotic mosaic orthotospovirus & bean necrotic mosaic virus (BeNMV) \\
\hline & Calla lily chlorotic spot orthotospovirus & calla lily chlorotic spot virus (CCSV) \\
\hline & Capsicum chlorosis orthotospovirus & Capsicum chlorosis virus (CaCV) \\
\hline & Chrysanthemum stem necrosis orthotospovirus & Chrysanthemum stem necrosis virus (CSNV) \\
\hline & Groundnut bud necrosis orthotospovirus & groundnut bud necrosis virus (GBNV) \\
\hline & Groundnut chlorotic fan spot orthotospovirus & groundnut chlorotic fan-spot virus (GCFSV) \\
\hline & Groundnut ringspot orthotospovirus & groundnut ringspot virus (GRSV) \\
\hline & Groundnut yellow spot orthotospovirus & groundnut yellow spot virus (GYSV) \\
\hline & Hippeastrum chlorotic ringspot orthotospovirus & Hippeastrum chlorotic spot virus (HCRV) \\
\hline & Impatiens necrotic spot orthotospovirus & impatiens necrotic spot virus (INSV) \\
\hline & Iris yellow spot orthotospovirus & iris yellow spot virus (IYSV) \\
\hline & Melon severe mosaic orthotospovirus & melon severe mosaic virus (MSMV) \\
\hline & Melon yellow spot orthotospovirus & melon yellow spot virus (MYSV) \\
\hline & Mulberry vein banding associated orthotospovirus & mulberry vein banding-associated virus (MVBaV) \\
\hline & Pepper chlorotic spot orthotospovirus & pepper chlorotic spot virus (PCSV) \\
\hline & Polygonum ringspot orthotospovirus & Polygonum ringspot virus (PolRSV) \\
\hline & Soybean vein necrosis orthotospovirus & soybean vein necrosis virus (SVNV) \\
\hline & Tomato chlorotic spot orthotospovirus & tomato chlorotic spot virus (TCSV) \\
\hline & Tomato spotted wilt orthotospovirus* & tomato spotted wilt virus (TSWV) \\
\hline & Tomato yellow ring orthotospovirus & tomato yellow ring virus (TYRV) \\
\hline & Tomato zonate spot orthotospovirus & tomato zonate spot virus (TZSV) \\
\hline & Watermelon bud necrosis orhtotospovirus & watermelon bud necrosis virus (WBNV) \\
\hline & Watermelon silver mottle orthotospovirus & watermelon silver mottle virus (WSMoV) \\
\hline & Zucchini lethal chlorosis orthotospovirus & zucchini lethal chlorosis virus (ZLCV) \\
\hline \multicolumn{3}{|c|}{ Family Wupedeviridae } \\
\hline Wumivirus & Millipede wumivirus* & Wǔhàn millipede virus 2 (WhMV-2) \\
\hline
\end{tabular}

Note that viruses are real objects that are assigned to concepts that are called taxa. Species, genera, subfamilies, families, and orders are taxa

*Type species

${ }^{1}$ Due to a formal classification mistake this species was named Lone Star bandavirus instead of Lone star bandavirus. A proposal to correct the spelling of this species name has been submitted

${ }^{2}$ Due to a formal classification mistake this species was named Salobo phlabovirus instead of Salobo phlebovirus. A proposal to correct the spelling of this species name has been submitted

${ }^{3}$ Due to a formal classification mistake this species was named Tico phebovirus instead of Tico phlebovirus. A proposal to correct the spelling of this species name has been submitted

ITaxon names are always italicized and always begin with a capital letter

${ }^{\&}$ Virus names are not italicized and are not capitalized, except if the name or a name component is a proper noun. This column lists the virus names with their correct (lack of) capitalization. Lists of viruses within a given species are provisional at this point and will likely be amended in the near future

Acknowledgements We thank W. Ian Lipkin and Rafal Tokarz (Columbia University Irving Medical Center, New York, New York, USA) for providing/approving new names for "blacklegged tick phleboviruses 1 and 3" and Edward Holmes (University of Sydney, Australia) for providing/approving a new name for "Norway phlebovirus". Many authors are current members of 2017-2020 International
Committee on Taxonomy of Viruses (ICTV) Study Groups: Arenaviridae (Jens H. Kuhn, Michael J. Buchmeier, Rémi N. Charrel, J. Christopher S. Clegg, Juan Carlos de la Torre, Jean-Paul J. Gonzalez, Stephan Günther, Mark D. Stenglein, Jussi Hepojoki, Manuela Sironi, Igor S. Lukashevich, Sheli R. Radoshitzky, Víctor Romanowski, Maria S. Salvato), Artoviridae (Jens H. Kuhn, Ralf G. Dietzgen, 
Dàohóng Jiāng, Nikos Vasilakis), Aspiviridae (John V. da Graça, Elena Dal Bó, Selma Gago-Zachert, María Laura García, John Hammond, Tomohide Natsuaki, José A. Navarro, Vicente Pallás, Carina A. Reyes, Gabriel Robles Luna, Takahide Sasaya, Ioannis Tzanetakis, Anna Maria Vaira, Martin Verbeek), Bornaviridae (Jens H. Kuhn, Thomas Briese, Ralf Dürrwald, Masayuki Horie, Timothy H. Hyndman, Norbert Nowotny, Susan Payne, Dennis Rubbenstroth, Mark D. Stenglein, Keizō Tomonaga), Bunyavirales (Jens H. Kuhn, Scott Adkins, Juan Carlos de la Torre, Sandra Junglen, Amy J. Lambert, Piet Maes, Marco Marklewitz, Gustavo Palacios, Takahide Sasaya, Yong-Zhen Zhang), Filoviridae (Jens H. Kuhn, Gaya K. Amarasinghe, Christopher Basler, Sina Bavari, Alexander Bukreyev, Kartik Chandran, Ian Crozier, Olga Dolnik, John M. Dye, Pierre B. H. Formenty, Anthony Griffiths, Roger Hewson, Gary Kobinger, Eric M. Leroy, Elke Mühlberger, Sergey V. Netesov, Gustavo Palacios, Bernadett Pályi, Janusz T. Pawęska, Sophie Smither, Ayato Takada, Jonathan S. Towner, Victoria Wahl), Fimoviridae (Michele Digiaro, Toufic Elbeaino, Giovanni P. Martelli, Nicole Mielke-Ehret, HansPeter Mühlbach), Hantaviridae (Steven Bradfute, Charles H. Calisher, Boris Klempa, Jonas Klingström, Lies Laenen, Piet Maes, JinWon Song, Yong-Zhen Zhang), Jingchuvirales (Nicholas Di Paola), Monjiviricetes (Jens H. Kuhn, Ralf G. Dietzgen, W. Paul Duprex, Dàohóng Jiāng, Piet Maes, Janusz T. Pawęska, Bertus K. Rima, Dennis Rubbenstroth, Peter J. Walker, Yong-Zhen Zhang), Mymonaviridae (María A. Ayllón, Dàohóng Jiāng, Shin-Yi L. Marzano), Nairoviridae (Jens H. Kuhn, Sergey V. Alkhovsky, Tatjana Avšič-Županc, Dennis A. Bente, Éric Bergeron, Felicity Burt, Nicholas Di Paola, Koray Ergünay, Aura R. Garrison, Roger Hewson, Ali Mirazimi, Gustavo Palacios, Anna Papa, Amadou Alpha Sall, Jessica R. Spengler), Negarnaviricota (Jens H. Kuhn, Eugene V. Koonin, Mart Krupovic, Yuri I. Wolf), Nyamiviridae (Jens H. Kuhn, Ralf G. Dietzgen, Dàohóng Jiāng, Nikos Vasilakis), Orthomyxoviridae (Justin Bahl, Inmaculada Casas, Adolfo García-Sastre, Seiji Hongo, Sergio H. Marshall, John W. McCauley, Gabriele Neumann, Colin R. Parrish, Daniel R. Pérez, Jonathan A. Runstadler, Martin Schwemmle), Paramyxoviridae (Anne Balkema-Buschmann, William G. Dundon, W. Paul Duprex, Andrew J. Easton, Ron Fouchier, Gael Kurath, Benhur Lee, Bertus K. Rima, Paul Rota, Lin-Fa Wang, Robobert A. Lamb), Peribunyaviridae (Scott Adkins, Sergey V. Alkhovsky, Martin Beer, Carol D. Blair, Charles H. Calisher, Michael A. Drebot, Holly R. Hughes, Amy J. Lambert, William Marciel de Souza, Marco Marklewitz, Márcio R. T. Nunes, Xiǎohóng Shí), Phasmaviridae (Matthew J. Ballinger, Roy A. Hall, Sandra Junglen, Stanley L. Langevin, Alex Pauvolid-Corrêa), Phenuiviridae (Thomas Briese, Rémi N. Charrel, Xavier De Lamballerie, Hideki Ebihara, George Fú Gāo, Martin H. Groschup, Márcio R. T. Nunes, Gustavo Palacios, Takahide Sasaya, Jin-Won Song), Pneumoviridae (Paul A. Brown, Ursula J. Buchholz, Rik L. de Swart, Jan Felix Drexler, W. Paul Duprex, Andrew J. Easton, Jiànróng Lǐ, Kirsten Spann, Natalie J. Thornburg, Bernadette van den Hoogen, John V. Williams), Rhabdoviridae (Kim R. Blasdell, Rachel Breyta, Ralf G. Dietzgen, Anthony R. Fooks, Juliana Freitas-Astúa, Hideki Kondō, Gael Kurath, Ivan V. Kuzmin, David M. Stone, Robert B. Tesh, Noël Tordo, Nikos Vasilakis, Peter J. Walker, Anna E. Whitfield), Sunviridae (Timothy H. Hyndman, Gael Kurath), Tenuivirus (Il-Ryong Choi, Gilda B. Jonson, Takahide Sasaya, Yukio Shirako, Tàiyún Wèi, Xueping Zhou), and Tospoviridae (Scott Adkins, Amy J. Lambert, Rayapati Naidu, Renato O. Resende, Massimo Turina, Anna E. Whitfield); or are ICTV Executive Committee Members: the 2017-2020 ICTV Chair of the Fungal and Protist Viruses Subcommittee (Peter Simmonds), the 2018-2020 ICTV Proposal Secretary (Peter J. Walker), the 2017-2020 ICTV Chair of the Plant Viruses Subcommittee (F. Murilo Zerbini), the 2017-2020 ICTV Chair of the Animal dsRNA and ssRNA- Viruses Subcommittee (Jens H. Kuhn), and 2017-2020 Elected Members (Sead Sabanadzovic, Arvind Varsani). We would like to thank Anya Crane (NIH/NIAID/DCR/IRF-Frederick) for critically editing the manuscript.

\section{Compliance with ethical standards}

The views and conclusions contained in this document are those of the authors and should not be interpreted as necessarily representing the official policies, either expressed or implied, of the US Department of the Army, the US Department of Defense, the US Department of Health and Human Services, the US Department of Homeland Security (DHS) Science and Technology Directorate (S\&T), or of the institutions and companies affiliated with the authors. The content of this publication does not necessarily reflect the views or policies of the Department of Health and Human Services, nor does mention of trade names, commercial products, or organizations imply endorsement by the U.S. Government. In no event shall any of these entities have any responsibility or liability for any use, misuse, inability to use, or reliance upon the information contained herein. The US departments do not endorse any products or commercial services mentioned in this publication. The US Government retains and the publisher, by accepting the article for publication, acknowledges that the United States Government retains a non-exclusive, paid up, irrevocable, world-wide license to publish or reproduce the published form of this manuscript, or allow others to do so, for United States Government purposes.

Funding This work was supported in part through Laulima Government Solutions, LLC prime contract with the US National Institute of Allergy and Infectious Diseases (NIAID) under Contract No. HHSN272201800013C. J.H.K. performed this work as an employee of Tunnell Government Services (TGS), a subcontractor of Laulima Government Solutions, LLC under Contract No. HHSN272201800013C. This project has been funded in whole or in part with federal funds from the National Cancer Institute (NCI), National Institutes of Health (NIH), under Contract No. 75N91019D00024, Task Order No. 75N91019F00130 to I.C., who was supported by the Clinical Monitoring Research Program Directorate, Frederick National Lab for Cancer Research, sponsored by NCI. This work was also funded in part by Contract No. HSHQDC-15-C-00064 awarded by the US Department of Homeland Security (DHS) Science and Technology Directorate (S\&T) for the management and operation of The National Biodefense Analysis and Countermeasures Center (NBACC), a federally funded research and development center operated by the Battelle National Biodefense Institute (V.W.); and NIH contract HHSN272201000040I/ HHSN27200004/D04 and grant R24AI120942 (N.V., R.B.T.). S.S. acknowledges partial support from the Special Research Initiative of Mississippi Agricultural and Forestry Experiment Station (MAFES), Mississippi State University, and the National Institute of Food and Agriculture, US Department of Agriculture, Hatch Project 1021494.

Conflict of interest The authors declare no conflicts of interest.

Ethical approval This article does not contain any studies with human participants or animals performed by any of the authors.

\section{References}

1. Abudurexiti A, Adkins S, Alioto D, Alkhovsky SV, AvšičŽupanc T, Ballinger MJ, Bente DA, Beer M, Bergeron É, Blair CD, Briese T, Buchmeier MJ, Burt FJ, Calisher CH, Cháng C, Charrel RN, Choi IR, Clegg JCS, de la Torre JC, de Lamballerie X, Dèng F, Di Serio F, Digiaro M, Drebot MA, Duàn X, Ebihara H, Elbeaino T, Ergünay K, Fulhorst CF, Garrison AR, Gāo GF, Gonzalez J-PJ, Groschup MH, Günther S, Haenni A-L, Hall RA, Hepojoki J, Hewson R, Hú Z, Hughes HR, Jonson MG, Junglen 
S, Klempa B, Klingström J, Kòu C, Laenen L, Lambert AJ, Langevin SA, Liu D, Lukashevich IS, Luò T, Lü C, Maes P, de Souza WM, Marklewitz M, Martelli GP, Matsuno K, Mielke-Ehret N, Minutolo M, Mirazimi A, Moming A, Mühlbach H-P, Naidu R, Navarro B, Nunes MRT, Palacios G, Papa A, Pauvolid-Corrêa A, Pawęska JT, Qiáo J, Radoshitzky SR, Resende RO, Romanowski V, Sall AA, Salvato MS, Sasaya T, Shěn S, Shí X, Shirako Y, Simmonds P, Sironi M, Song J-W, Spengler JR, Stenglein MD, Sū Z, Sūn S, Táng S, Turina M, Wáng B, Wáng C, Wáng H, Wáng J, Wèi T, Whitfield AE, Zerbini FM, Zhāng J, Zhāng L, Zhāng Y, Zhang Y-Z, Zhāng Y, Zhou X, Zhū L, Kuhn JH (2019) Taxonomy of the order Bunyavirales: update 2019. Arch Virol 164:1949-1965

2. Afonso CL, Amarasinghe GK, Bányai K, Bào Y, Basler CF, Bavari S, Bejerman N, Blasdell KR, Briand F-X, Briese T, Bukreyev A, Calisher CH, Chandran K, Chéng J, Clawson AN, Collins PL, Dietzgen RG, Dolnik O, Domier LL, Dürrwald R, Dye JM, Easton AJ, Ebihara H, Farkas SL, Freitas-Astúa J, Formenty P, Fouchier RA, Fù Y, Ghedin E, Goodin MM, Hewson R, Horie M, Hyndman TH, Jiāng D, Kitajima EW, Kobinger GP, Kondo H, Kurath G, Lamb RA, Lenardon S, Leroy EM, Li C-X, Lin X-D, Liú L, Longdon B, Marton S, Maisner A, Mühlberger E, Netesov SV, Nowotny N, Patterson JL, Payne SL, Paweska JT, Randall RE, Rima BK, Rota P, Rubbenstroth D, Schwemmle M, Shi M, Smither SJ, Stenglein MD, Stone DM, Takada A, Terregino C, Tesh RB, Tian J-H, Tomonaga K, Tordo N, Towner JS, Vasilakis N, Verbeek M, Volchkov VE, Wahl-Jensen V, Walsh JA, Walker PJ, Wang D, Wang L-F, Wetzel T, Whitfield AE, Xiè JT, Yuen K-Y, Zhang Y-Z, Kuhn JH (2016) Taxonomy of the order Mononegavirales: update 2016. Arch Virol 161:2351-2360

3. Aitken TH, Woodall JP, De Andrade AHP, Bensabath G, Shope RE (1975) Pacui virus, phlebotomine flies, and small mammals in Brazil: an epidemiological study. Am J Trop Med Hyg 24:358-368

4. Alkan C, Alwassouf S, Piorkowski G, Bichaud L, Tezcan S, Dincer E, Ergunay K, Ozbel Y, Alten B, de Lamballerie X, Charrel RN (2015) Isolation, genetic characterization, and seroprevalence of Adana virus, a novel phlebovirus belonging to the Salehabad virus complex, in Turkey. J Virol 89:4080-4091

5. Alkan C, Erisoz Kasap O, Alten B, de Lamballerie X, Charrel RN (2016) Sandfly-borne phlebovirus isolations from Turkey: new insight into the Sandfly fever Sicilian and Sandfly fever Naples Species. PLoS Negl Trop Dis 10:e0004519

6. Alkan C, Moin Vaziri V, Ayhan N, Badakhshan M, Bichaud L, Rahbarian N, Javadian E-A, Alten B, de Lamballerie X, Charrel RN (2017) Isolation and sequencing of Dashli virus, a novel Sicilian-like virus in sandflies from Iran; genetic and phylogenetic evidence for the creation of one novel species within the Phlebovirus genus in the Phenuiviridae family. PLoS Negl Trop Dis 11:e005978

7. Amarasinghe GK, Bào Y, Basler CF, Bavari S, Beer M, Bejerman N, Blasdell KR, Bochnowski A, Briese T, Bukreyev A, Calisher $\mathrm{CH}$, Chandran K, Collins PL, Dietzgen RG, Dolnik O, Dürrwald R, Dye JM, Easton AJ, Ebihara H, Fang Q, Formenty P, Fouchier RAM, Ghedin E, Harding RM, Hewson R, Higgins CM, Hong J, Horie M, James AP, Jiāng D, Kobinger GP, Kondo H, Kurath G, Lamb RA, Lee B, Leroy EM, Li M, Maisner A, Mühlberger E, Netesov SV, Nowotny N, Patterson JL, Payne SL, Paweska JT, Pearson MN, Randall RE, Revill PA, Rima BK, Rota P, Rubbenstroth D, Schwemmle M, Smither SJ, Song Q, Stone DM, Takada A, Terregino C, Tesh RB, Tomonaga K, Tordo N, Towner JS, Vasilakis N, Volchkov VE, Wahl-Jensen V, Walker PJ, Wang B, Wang D, Wang F, Wang L-F, Werren JH, Whitfield AE, Yan Z, Ye G, Kuhn JH (2017) Taxonomy of the order Mononegavirales: update 2017. Arch Virol 162:2493-2504
8. Amarasinghe GK, Ceballos NGA, Banyard AC, Basler CF, Bavari S, Bennett AJ, Blasdell KR, Briese T, Bukreyev A, Caì $\mathrm{Y}$, Calisher CH, Lawson CC, Chandran K, Chapman CA, Chiu CY, Choi K-S, Collins PL, Dietzgen RG, Dolja VV, Dolnik O, Domier LL, Dürrwald R, Dye JM, Easton AJ, Ebihara H, Echevarría JE, Fooks AR, Formenty PBH, Fouchier RAM, Freuling CM, Ghedin E, Goldberg TL, Hewson R, Horie M, Hyndman TH, Jiāng D, Kityo R, Kobinger GP, Kondō H, Koonin EV, Krupovic M, Kurath G, Lamb RA, Lee B, Leroy EM, Maes P, Maisner A, Marston DA, Mor SK, Müller T, Mühlberger E, Ramírez VMN, Netesov SV, Ng TFF, Nowotny N, Palacios G, Patterson JL, Pawęska JT, Payne SL, Prieto K, Rima BK, Rota P, Rubbenstroth D, Schwemmle M, Siddell S, Smither SJ, Song Q, Song T, Stenglein MD, Stone DM, Takada A, Tesh RB, Thomazelli LM, Tomonaga K, Tordo N, Towner JS, Vasilakis N, Vázquez-Morón S, Verdugo C, Volchkov VE, Wahl V, Walker PJ, Wang D, Wang L-F, Wellehan JFX, Wiley MR, Whitfield AE, Wolf YI, Yè G, Zhāng Y-Z, Kuhn JH (2018) Taxonomy of the order Mononegavirales: update 2018. Arch Virol 163:2283-2294

9. Amarasinghe GK, Ayllón MA, Bào Y, Basler CF, Bavari S, Blasdell KR, Briese T, Brown PA, Bukreyev A, Balkema-Buschmann A, Buchholz UJ, Chabi-Jesus C, Chandran K, Chiapponi C, Crozier I, de Swart RL, Dietzgen RG, Dolnik O, Drexler JF, Dürrwald R, Dundon WG, Duprex WP, Dye JM, Easton AJ, Fooks AR, Formenty PBH, Fouchier RAM, Freitas-Astúa J, Griffiths A, Hewson R, Horie M, Hyndman TH, Jiāng D, Kitajima EW, Kobinger GP, Kondō H, Kurath G, Kuzmin IV, Lamb RA, Lavazza A, Lee B, Lelli D, Leroy EM, Lǐ J, Maes P, Marzano S-YL, Moreno A, Mühlberger E, Netesov SV, Nowotny N, Nylund A, Økland AL, Palacios G, Pályi B, Pawęska JT, Payne SL, Prosperi A, Ramos-González PL, Rima BK, Rota P, Rubbenstroth D, Shī M, Simmonds P, Smither SJ, Sozzi E, Spann K, Stenglein MD, Stone DM, Takada A, Tesh RB, Tomonaga K, Tordo N, Towner JS, van den Hoogen B, Vasilakis N, Wahl V, Walker PJ, Wang L-F, Whitfield AE, Williams JV, Zerbini FM, Zhāng T, Zhang Y-Z, Kuhn JH (2019) Taxonomy of the order Mononegavirales: update 2019. Arch Virol 164:1967-1980

10. Amaro F, Zé-Zé L, Alves MJ, Börstler J, Clos J, Lorenzen S, Becker SC, Schmidt-Chanasit J, Cadar D (2015) Co-circulation of a novel phlebovirus and Massilia virus in sandflies, Portugal. Virol J 12:174

11. Barr J, Smith C, Smith I, de Jong C, Todd S, Melville D, Broos A, Crameri S, Haining J, Marsh G, Crameri G, Field H, Wang LF (2015) Isolation of multiple novel paramyxoviruses from pteropid bat urine. J Gen Virol 96:24-29

12. Bejerman N, de Breuil S, Debat H, Miretti M, Badaracco A, Nome C (2017) Molecular characterization of yerba mate chlorosis-associated virus, a putative cytorhabdovirus infecting yerba mate (Ilex paraguariensis). Arch Virol 162:2481-2484

13. Berge TO (1975) International Catalogue of Arboviruses Including Certain Other Viruses of Vertebrates. US Public Health Service publication no. (CDC) 75-8301, 2nd edn. Department of Health, Education and Welfare, Washington, DC

14. Bhatt PN, Kulkarni KG, Boshell MJ, Rajagopalan PK, Patil AP, Goverdhan MK, Pavri KM (1966) Kaisodi virus, a new agent isolated from Haemaphysalis spinigera in Mysore State, South India. I. Isolation of strains. Am J Trop Med Hyg 15:958-960

15. Bichaud L, Dachraoui K, Alwassouf S, Alkan C, Mensi M, Piorkowski G, Sakhria S, Seston M, Fares W, De Lamballerie X, Zhioua E, Charrel RN (2016) Isolation, full genomic characterization and neutralization-based human seroprevalence of Medjerda Valley virus, a novel sandfly-borne phlebovirus belonging to the Salehabad virus complex in northern Tunisia. J Gen Virol 97:602-610 
16. Bishop DHL, Pringle CR (1995) Order Mononegavirales. In: Murphy FA, Fauquet CM, Bishop DHL, Ghabrial SA, Jarvis AW, Martelli GP, Mayo MA, Summers MD (eds) Virus taxonomy - sixth report of the international committee on taxonomy of viruses/archives of virology supplement 10. Springer, Vienna, pp 265-267

17. Bouquet J, Melgar M, Swei A, Delwart E, Lane RS, Chiu CY (2017) Metagenomic-based surveillance of Pacific Coast tick Dermacentor occidentalis identifies two novel bunyaviruses and an emerging human ricksettsial pathogen. Sci Rep 7:12234

18. Buzkan N, Chiumenti M, Massart S, Sarpkaya K, Karadağ S, Minafra A (2019) A new emaravirus discovered in Pistacia from Turkey. Virus Res 263:159-163

19. Causey OR, Shope RE (1965) Icoaraci, a new virus related to Naples phlebotomus fever virus. Proc Soc Exp Biol Med 118:420-421

20. Charrel RN, Moureau G, Temmam S, Izri A, Marty P, Parola P, da Rosa AT, Tesh RB, de Lamballerie X (2009) Massilia virus, a novel Phlebovirus (Bunyaviridae) isolated from sandflies in the Mediterranean. Vector Borne Zoonotic Dis 9:519-530

21. Chen CC, Chiu RJ (1996) A tospovirus infecting peanut in Taiwan. Acta Hortic 431:57-67

22. Cheng Y-H, Zheng Y-X, Tai C-H, Yen J-H, Chen Y-K, Jan F-J (2014) Identification, characterisation and detection of a new tospovirus on sweet pepper. Ann Appl Biol 164:107-115

23. Coffey LL, Page BL, Greninger AL, Herring BL, Russell RC, Doggett SL, Haniotis J, Wang C, Deng X, Delwart EL (2014) Enhanced arbovirus surveillance with deep sequencing: identification of novel rhabdoviruses and bunyaviruses in Australian mosquitoes. Virology 448:146-158

24. de Carvalho MS, de Lara Pinto AZ, Pinheiro A, Rodrigues JSV, Melo FL, da Silva LA, Ribeiro BM, Dezengrini-Slhessarenko R (2018) Viola phlebovirus is a novel Phlebotomus fever serogroup member identified in Lutzomyia (Lutzomyia) longipalpis from Brazilian Pantanal. Parasit Vectors 11:405

25. De Haas RA, Jonkers AH, Heinemann DW (1966) Kwatta virus, a new agent isolated from Culex mosquitoes in Surinam. Am J Trop Med Hyg 15:954-957

26. Debat HJ, Bejerman N (2019) Novel bird's-foot trefoil RNA viruses provide insights into a clade of legume-associated enamoviruses and rhabdoviruses. Arch Virol 164:1419-1426

27. Dilcher M, Alves MJ, Finkeisen D, Hufert F, Weidmann M (2012) Genetic characterization of Bhanja virus and Palma virus, two tick-borne phleboviruses. Virus Genes 45:311-315

28. Dilcher M, Faye O, Faye O, Weber F, Koch A, Sadegh C, Weidmann M, Sall AA (2015) Zahedan rhabdovirus, a novel virus detected in ticks from Iran. Virol J 12:183

29. Doherty RL, Carley JG, Standfast HA, Dyce AL, Kay BH, Snowdon WA (1973) Isolation of arboviruses from mosquitoes, biting midges, sandflies and vertebrates collected in Queensland, 1969 and 1970. Trans R Soc Trop Med Hyg 67:536-543

30. Dong J-H, Cheng X-F, Yin YY, Fang Q, Ding M, Li T-T, Zhang L-Z, Su X-X, McBeath J-H, Zhang Z-K (2008) Characterization of tomato zonate spot virus, a new tospovirus in China. Arch Virol 153:855-864

31. Dong JH, Yin YY, Fang Q, McBeath JH, Zhang ZK (2013) A new tospovirus causing chlorotic ringspot on Hippeastrum sp. in China. Virus Genes 46:567-570

32. Easton AJ, Pringle CR (2011) Order Mononegavirales. In: King AMQ, Adams MJ, Carstens EB, Lefkowitz EJ (eds) Virus taxonomy - ninth report of the international committee on taxonomy of viruses. Elsevier/Academic Press, London, pp 653-657

33. Fernandes J, Guterres A, de Oliveira RC, Chamberlain J, Lewandowski K, Teixeira BR, Coelho TA, Crisóstomo CF, Bonvicino CR, D'Andrea PS, Hewson R, de Lemos ERS (2018) Xapuri virus, a novel mammarenavirus: natural reassortment and increased diversity between New World viruses. Emerg Microbes Infect 7:120

34. Fernandes J, Guterres A, de Oliveira RC, Jardim R, Dávila AMR, Hewson R, de Lemos ERS (2019) Apore virus, a novel mammarenavirus (Bunyavirales: Arenaviridae) related to highly pathogenic virus from South America. Mem Inst Oswaldo Cruz 114:e180586

35. Forth LF, Konrath A, Klose K, Schlottau K, Hoffmann K, Ulrich RG, Höper D, Pohlmann A, Beer M (2018) A novel squirrel respirovirus with putative zoonotic potential. Viruses 10:373

36. Gaafar YZA, Richert-Pöggeler KR, Maaß C, Vetten H-J, Ziebell $\mathrm{H}$ (2019) Characterisation of a novel nucleorhabdovirus infecting alfalfa (Medicago sativa). Virol J 16:55

37. Goldstein T, Anthony SJ, Gbakima A, Bird BH, Bangura J, Tremeau-Bravard A, Belaganahalli MN, Wells HL, Dhanota JK, Liang E, Grodus M, Jangra RK, DeJesus VA, Lasso G, Smith BR, Jambai A, Kamara BO, Kamara S, Bangura W, Monagin C, Shapira S, Johnson CK, Saylors K, Rubin EM, Chandran K, Lipkin WI, Mazet JAK (2018) The discovery of Bombali virus adds further support for bats as hosts of ebolaviruses. Nat Microbiol 3:1084-1089

38. Gubala A, Walsh S, McAllister J, Weir R, Davis S, Melville L, Mitchell I, Bulach D, Gauci P, Skvortsov A, Boyle D (2017) Identification of very small open reading frames in the genomes of Holmes Jungle virus, Ord River virus, and Wongabel virus of the genus Hapavirus, family Rhabdoviridae. Evol Bioinform Online 13:1176934317713484

39. Hang J, Klein TA, Kim H-C, Yang Y, Jima DD, Richardson JH, Jarman RG (2016) Genome sequences of five arboviruses in field-captured mosquitoes in a unique rural environment of South Korea. Genome Announc 4:e01644-15

40. Hannoun C, Corniou B, Rageau J (1970) Isolation in southern France and characterization of new tick-borne viruses related to Uukuniemi: Grand Arbaud and Ponteves. Acta Virol $14: 167-170$

41. Hassan M, Di Bello PL, Keller KE, Martin RR, Sabanadzovic S, Tzanetakis IE (2017) A new, widespread emaravirus discovered in blackberry. Virus Res 235:1-5

42. Hassani-Mehraban A, Botermans M, Verhoeven JTJ, Meekes E, Saaijer J, Peters D, Goldbach R, Kormelink R (2010) A distinct tospovirus causing necrotic streak on Alstroemeria sp. in Colombia. Arch Virol 155:423-428

43. Hassani-Mehraban A, Dullemans AM, Verhoeven JTJ, Roenhorst JW, Peters D, van der Vlugt RAA, Kormelink R (2019) Alstroemeria yellow spot virus (AYSV): a new orthotospovirus species within a growing Eurasian clade. Arch Virol 164:117-126

44. Hepojoki J, Hepojoki S, Smura T, Szirovicza L, Dervas E, Prahauser B, Nufer L, Schraner EM, Vapalahti O, Kipar A, Hetzel U (2018) Characterization of Haartman Institute snake virus-1 (HISV-1) and HISV-like viruses - the representatives of genus Hartmanivirus, family Arenaviridae. PLoS Pathog 14:e1007415

45. Hu S-C, Hsu C-L, Lee M-S, Tu Y-C, Chang J-C, Wu C-H, Lee S-H, Ting L-J, Tsai K-R, Cheng M-C, Tu W-J, Hsu W-C (2018) Lyssavirus in Japanese pipistrelle, Taiwan. Emerg Infect Dis 24:782-785

46. Hughes HR, Russell BJ, Lambert AJ (2020) Genetic characterization of Frijoles and Chilibre species complex viruses (genus Phlebovirus; family Phenuiviridae) and three unclassified New World phleboviruses. Am J Trop Med Hyg 102:359-365

47. Ito T, Suzaki K, Nakano M (2013) Genetic characterization of novel putative rhabdovirus and dsRNA virus from Japanese persimmon. J Gen Virol 94:1917-1921

48. Jeong J, Kim Y, An I, Wang S-J, Kim Y, Lee H-J, Choi K-S, Im S-P, Min W, Oem J-K, Jheong W (2018) Complete genome sequence of a novel avian paramyxovirus isolated from wild birds in South Korea. Arch Virol 163:223-227 
49. Johnson RI, Tachedjian M, Rowe B, Clayton BA, Layton R, Bergfeld J, Wang L-F, Marsh GA (2018) Alston virus, a novel paramyxovirus isolated from bats causes upper respiratory tract infection in experimentally challenged ferrets. Viruses 10:675

50. Jones S, McGavin W, MacFarlane S (2019) The complete sequences of two divergent variants of the rhabdovirus raspberry vein chlorosis virus and the design of improved primers for virus detection. Virus Res 265:162-165

51. Karabatsos N (1985) International catalogue of arboviruses including certain other viruses of vertebrates. American Society for Tropical Medicine and Hygiene, San Antonio

52. Kerschner JH, Calisher CH, Vorndam AV, Francy DB (1986) Identification and characterization of Bahia Grande, Reed Ranch and Muir Springs viruses, related members of the family Rhabdoviridae with widespread distribution in the United States. J Gen Virol 67:1081-1089

53. Kohl C, Tachedjian M, Todd S, Monaghan P, Boyd V, Marsh GA, Crameri G, Field H, Kurth A, Smith I, Wang L-F (2018) Hervey virus: a study on co-circulation with henipaviruses in pteropid bats within their distribution range from Australia to Africa. PLoS One 13:e0191933

54. Kokernot RH, Calisher CH, Stannard LJ, Hayes J (1969) Arbovirus studies in the Ohio-Mississippi Basin, 1964-1967. VII. Lone star virus, a hitherto unknown agent isolated from the tick Amblyomma americanum (Linn.). Am J Trop Med Hyg 18:789-795

55. Koonin EV, Dolja VV, Krupovic M, Arvind V, Wolf YI, Yutin N, Zerbini FM, Kuhn JH (2020) Global organization and proposed megataxonomy of the virus world. Microbiol Mol Biol Rev 84:e00061-19

56. Kuhn JH, Wolf YI, Krupovic M, Zhang Y-Z, Maes P, Dolja VV, Koonin EV (2019) Classify viruses - the gain is worth the pain. Nature 566:318-320

57. Lecoq H, Wipf-Scheibel C, Verdin E, Desbiez C (2019) Characterization of the first tenuivirus naturally infecting dicotyledonous plants. Arch Virol 164:297-301

58. Ledermann JP, Zeidner N, Borland EM, Mutebi J-P, Lanciotti RS, Miller BR, Lutwama JJ, Tendo JM, Andama V, Powers AM (2014) Sunguru virus: a novel virus in the family Rhabdoviridae isolated from a chicken in north-western Uganda. J Gen Virol 95:1436-1443

59. Li C-X, Shi M, Tian J-H, Lin X-D, Kang Y-J, Chen L-J, Qin X-C, Xu J, Holmes EC, Zhang Y-Z (2015) Unprecedented genomic diversity of RNA viruses in arthropods reveals the ancestry of negative-sense RNA viruses. Elife 4:e05378

60. Lin Y-H, Fujita M, Chiba S, Hyodo K, Andika IB, Suzuki N, Kondo H (2019) Two novel fungal negative-strand RNA viruses related to mymonaviruses and phenuiviruses in the shiitake mushroom (Lentinula edodes). Virology 533:125-136

61. Liu Y, Du Z, Wang H, Zhang S, Cao M, Wang X (2018) Identification and characterization of wheat yellow striate virus, a novel leafhopper-transmitted nucleorhabdovirus infecting wheat. Front Microbiol 9:468

62. Lvov DK, Timopheeva AA, Gromashevski VL, Gostinshchikova GV, Veselovskaya OV, Chervonski VI, Fomina KB, Gromov AI, Pogrebenko AG, Zhezmer VY (1973) "Zaliv Terpeniya" virus, a new Uukuniemi group arbovirus isolated from Ixodes (Ceratixodes) putus Pick.-Camb. 1878 on Tyuleniy Island (Sakhalin region) and Commodore Islands (Kamchatsk region). Arch Gesamte Virusforsch 41:165-169

63. Lvov SD, Gromashevsky VL, Andreev VP, Skvortsova TM, Kondrashina NG, Morozova TN, Avershin AD, Aristova VA, Dmitriev GA, Kandaurov YK, Kuznetsov AA, Galkina IV, Yamnikova SS, Shchipanova MV (1990) Natural foci of arboviruses in far northern latitudes of Eurasia. In: Calisher CH (ed) Hemorrhagic fever with renal syndrome, tick- and mosquito-borne viruses. Springer, Vienna, pp 267-275
64. Maes P, Alkhovsky SV, Bào Y, Beer M, Birkhead M, Briese T, Buchmeier MJ, Calisher CH, Charrel RN, Choi IR, Clegg CS, Torre JC, Delwart E, DeRisi JL, Bello PLD, Serio FD, Digiaro M, Dolja VV, Drosten C, Druciarek TZ, Du J, Ebihara H, Elbeaino T, Gergerich RC, Gillis AN, Gonzalez J-PJ, Haenni A-L, Hepojoki J, Hetzel U, Hồ T, Hóng N, Jain RK, Vuren PJv, Jin Q, Jonson MG, Junglen S, Keller KE, Kemp A, Kipar A, Kondov NO, Koonin EV, Kormelink R, Korzyukov Y, Krupovic M, Lambert AJ, Laney AG, LeBreton M, Lukashevic IS, Marklewitz M, Markotter W, Martelli GP, Martin RR, Mielke-Ehret N, Mühlbach H-P, Navarro B, Ng TFF, Nunes MRT, Palacios G, Pawęska JT, Peters CJ, Plyusnin A, Radoshitzky SR, Romanowski V, Salmenperä P, Salvato MS, Sanfaçon H, Sasaya T, Schmaljohn C, Schneider BS, Shirako Y, Siddell S, Sironen TA, Stenglein MD, Storm N, Sudini H, Tesh RB, Tzanetakis IE, Uppala M, Vapalahti O, Vasilakis N, Walker PJ, Wáng G, Wáng L, Wáng Y, Wèi T, Wiley MR, Wolf YI, Wolfe ND, Wú Z, Xú W, Yang L, Yāng Z, Yeh S-D, Zhāng Y-Z, Zhèng Y, Zhou X, Zhū C, Zirkel F, Kuhn JH (2018) Taxonomy of the family Arenaviridae and the order Bunyavirales: update 2018. Arch Virol 163:2295-310

65. Maes P, Adkins S, Alkhovsky SV, Avšič-Županc T, Ballinger MJ, Bente DA, Beer M, Bergeron É, Blair CD, Briese T, Buchmeier MJ, Burt FJ, Calisher CH, Charrel RN, Choi IR, Clegg JCS, de la Torre JC, de Lamballerie X, DeRisi JL, Digiaro M, Drebot M, Ebihara H, Elbeaino T, Ergünay K, Fulhorst CF, Garrison AR, Gāo GF, Gonzalez J-PJ, Groschup MH, Günther S, Haenni A-L, Hall RA, Hewson R, Hughes HR, Jain RK, Jonson MG, Junglen S, Klempa B, Klingström J, Kormelink R, Lambert AJ, Langevin SA, Lukashevich IS, Marklewitz M, Martelli GP, Mielke-Ehret N, Mirazimi A, Mühlbach H-P, Naidu R, Nunes MRT, Palacios G, Papa A, Pawęska JT, Peters CJ, Plyusnin A, Radoshitzky SR, Resende RO, Romanowski V, Sall AA, Salvato MS, Sasaya T, Schmaljohn C, Shí X, Shirako Y, Simmonds P, Sironi M, Song J-W, Spengler JR, Stenglein MD, Tesh RB, Turina M, Wèi T, Whitfield AE, Yeh S-D, Zerbini FM, Zhang Y-Z, Zhou X, Kuhn JH (2019) Taxonomy of the order Bunyavirales: second update 2018. Arch Virol 164:927-41

66. Maes P, Amarasinghe GK, Ayllón MA, Basler CF, Bavari S, Blasdell KR, Briese T, Brown PA, Bukreyev A, BalkemaBuschmann A, Buchholz UJ, Chandran K, Crozier I, de Swart RL, Dietzgen RG, Dolnik O, Domier LL, Drexler JF, Dürrwald R, Dundon WG, Duprex WP, Dye JM, Easton AJ, Fooks AR, Formenty PBH, Fouchier RAM, Freitas-Astúa J, Ghedin E, Griffiths A, Hewson R, Horie M, Hurwitz JL, Hyndman TH, Jiāng D, Kobinger GP, Kondō H, Kurath G, Kuzmin IV, Lamb RA, Lee B, Leroy EM, Lǐ J, Marzano S-YL, Mühlberger E, Netesov SV, Nowotny N, Palacios G, Pályi B, Pawęska JT, Payne SL, Rima BK, Rota P, Rubbenstroth D, Simmonds P, Smither SJ, Song Q, Song T, Spann K, Stenglein MD, Stone DM, Takada A, Tesh RB, Tomonaga K, Tordo N, Towner JS, van den Hoogen B, Vasilakis N, Wahl V, Walker PJ, Wang D, Wang L-F, Whitfield AE, Williams JV, Yè G, Zerbini FM, Zhang Y-Z, Kuhn JH (2019) Taxonomy of the order Mononegavirales: second update 2018. Arch Virol 164:1233-1244

67. Main AJ, Carey AB (1980) Connecticut virus: a new Sawgrass group virus from Ixodes dentatus (Acari: Ixodidae). J Med Entomol 17:473-476

68. Marklewitz M, Dutari LC, Paraskevopoulou S, Page RA, Loaiza JR, Junglen S (2019) Diverse novel phleboviruses in sandflies from the Panama Canal area, Central Panama. J Gen Virol 100:938-949

69. Matsuno K, Weisend C, Kajihara M, Matysiak C, Williamson BN, Simuunza M, Mweene AS, Takada A, Tesh RB, Ebihara H (2015) Comprehensive molecular detection of tick-borne phleboviruses leads to the retrospective identification of taxonomically 
unassigned bunyaviruses and the discovery of a novel member of the genus Phlebovirus. J Virol 89:594-604

70. Maurino F, Dumón AD, Llauger G, Alemandri V, de Haro LA, Mattio MF, Del Vas M, Laguna IG, MdlP Giménez Pecci (2018) Complete genome sequence of maize yellow striate virus, a new cytorhabdovirus infecting maize and wheat crops in Argentina. Arch Virol 163:291-295

71. McAllister J, Gauci PJ, Mitchell IR, Boyle DB, Bulach DM, Weir RP, Melville LF, Davis SS, Gubala AJ (2014) Genomic characterisation of Almpiwar virus, Harrison Dam virus and Walkabout Creek virus; three novel rhabdoviruses from northern Australia. Virol Rep 3-4:1-17

72. McLean DM, Larke RPB (1963) Powassan and Silverwater viruses: ecology of two Ontario arboviruses. Can Med Assoc J 88:182-185

73. Medina-Salguero AX, Cornejo-Franco JF, Grinstead S, Mollov D, Mowery JD, Flores F, Quito-Avila DF (2019) Sequencing, genome analysis and prevalence of a cytorhabdovirus discovered in Carica papaya. PLoS One 14:e215798

74. Meng J, Liu P, Zhu L, Zou C, Li J, Chen B (2015) Complete genome sequence of mulberry vein banding associated virus, a new tospovirus infecting mulberry. PLoS One 10:e0136196

75. Meng JR, Liu PP, Zou CW, Wang ZQ, Liao YM, Cai JH, Qin BX, Chen BS (2013) First report of a Tospovirus in mulberry. Plant Dis $97: 1001$

76. Menzel W, Richert-Pöggeler KR, Winter S, Knierim D (2018) Characterization of a nucleorhabdovirus from Physostegia. Acta Hortic 1193:29-38

77. Muller MJ, Standfast HA (1986) Vectors of ephemeral fever group viruses. In: St George TD, Kay BH, Blok J (eds) Arbovirus research in Australia-proceedings of the fourth symposium. CSIRO/QMIR, Brisbane, pp 295-300

78. Navarro B, Zicca S, Minutolo M, Saponari M, Alioto D, Di Serio F (2018) A negative-stranded RNA virus infecting citrus trees: the second member of a new genus within the order Bunyavirales. Front Microbiol 9:2340

79. Noh JY, Jeong DG, Yoon S-W, Kim JH, Choi YG, Kang S-Y, Kim HK (2018) Isolation and characterization of novel bat paramyxovirus B16-40 potentially belonging to the proposed genus Shaanvirus. Sci Rep 8:12533

80. Nunes-Neto JP, Souza WM, Acrani GO, Romeiro MF, Fumagalli M, Vieira LC, Medeiros DBdA, Lima JA, de Lima CPS, Cardoso JF, Figueiredo LTM, da Silva SPD, Tesh R, Nunes MRT, Vasconcelos PFdC (2017) Characterization of the Bujaru, frijoles and Tapara antigenic complexes into the sandfly fever group and two unclassified phleboviruses from Brazil. J Gen Virol 98:585-594

81. Økland AL, Nylund A, Øvergård A-C, Skoge RH, Kongshaug H (2019) Genomic characterization, phylogenetic position and in situ localization of a novel putative mononegavirus in Lepeophtheirus salmonis. Arch Virol 164:675-689

82. Palacios G, da Rosa AT, Savji N, Sze W, Wick I, Guzman H, Hutchison S, Tesh R, Lipkin WI (2011) Aguacate virus, a new antigenic complex of the genus Phlebovirus (family Bunyaviridae). J Gen Virol 92:1445-1453

83. Palacios G, Tesh R, Travassos da Rosa A, Savji N, Sze W, Jain K, Serge R, Guzman H, Guevara C, Nunes MR, NunesNeto JP, Kochel T, Hutchison S, Vasconcelos PFC, Lipkin WI (2011) Characterization of the Candiru antigenic complex (Bunyaviridae: Phlebovirus), a highly diverse and reassorting group of viruses affecting humans in tropical America. J Virol 85:3811-3820

84. Palacios G, Savji N, Travassos da Rosa A, Desai A, SanchezSeco MP, Guzman H, Lipkin WI, Tesh R (2013) Characterization of the Salehabad virus species complex of the genus Phlebovirus (Bunyaviridae). J Gen Virol 94:837-842
85. Palacios G, Savji N, Travassos da Rosa A, Guzman H, Yu X, Desai A, Rosen GE, Hutchison S, Lipkin WI, Tesh R (2013) Characterization of the Uukuniemi virus group (Phlebovirus: Bunyaviridae): evidence for seven distinct species. J Virol 87:3187-3195

86. Palacios G, Tesh RB, Savji N, Travassos da Rosa APA, Guzman H, Bussetti AV, Desai A, Ladner J, Sanchez-Seco M, Lipkin WI (2014) Characterization of the Sandfly fever Naples species complex and description of a new Karimabad species complex (genus Phlebovirus, family Bunyaviridae). J Gen Virol 95:292-300

87. Palacios G, Wiley MR, Travassos da Rosa APA, Guzman H, Quiroz E, Savji N, Carrera J-P, Bussetti AV, Ladner JT, Lipkin WI, Tesh RB (2015) Characterization of the Punta Toro species complex (genus Phlebovirus, family Bunyaviridae). J Gen Virol 96:2079-2085

88. Pavri KM, Casals J (1966) Kaisodi virus, a new agent isolated from Haemaphysalis spinigera in Mysore state, South India. Am J Trop Med Hyg 15:961-963

89. Pecman A, Kutnjak D, Gutiérrez-Aguirre I, Adams I, Fox A, Boonham N, Ravnikar M (2017) Next generation sequencing for detection and discovery of plant viruses and viroids: comparison of two approaches. Front Microbiol 8:1998

90. Peralta PH, Shelokov A, Brody JA (1965) Chagres virus: a new human isolate from Panama. Am J Trop Med Hyg 14:146-151

91. Pettersson JH-O, Shi M, Bohlin J, Eldholm V, Brynildsrud OB, Paulsen KM, Andreassen Å, Holmes EC (2017) Characterizing the virome of Ixodes ricinus ticks from northern Europe. Sci Rep $7: 10870$

92. Pringle CR, Alexander DJ, Billeter MA, Collins PL, Kingsbury DW, Lipkind MA, Nagai Y, Orvell C, Rima B, Rott R, ter Meulen V (1991) The order Mononegavirales. Arch Virol 117:137-140

93. Pringle CR (1997) The order Mononegavirales — current status. Arch Virol 142:2321-2326

94. Pringle CR (2000) Order Mononegavirales. In: van Regenmortel MHV, Fauquet CM, Bishop DHL, Carstens EB, Estes MK, Lemon SM, Maniloff J, Mayo MA, McGeoch DJ, Pringle CR, Wickner RB (eds) Virus taxonomy-seventh report of the international committee on taxonomy of viruses. Academic Press, San Diego, pp 525-530

95. Pringle CR (2005) Order Mononegavirales. In: Fauquet CM, Mayo MA, Maniloff J, Desselberger U, Ball LA (eds) Virus taxonomy-eighth report of the international committee on taxonomy of viruses. Elsevier/Academic Press, San Diego, pp 609-614

96. Quan P-L, Williams DT, Johansen CA, Jain K, Petrosov A, Diviney SM, Tashmukhamedova A, Hutchison SK, Tesh RB, Mackenzie JS, Briese T, Lipkin WI (2011) Genetic characterization of K13965, a strain of Oak Vale virus from Western Australia. Virus Res 160:206-213

97. Read DA, Featherston J, Rees DJG, Thompson GD, Roberts R, Flett BC, Mashingaidze K, Pietersen G, Kiula B, Kullaya A, Mbega ER (2019) Molecular characterization of Morogoro maize-associated virus, a nucleorhabdovirus detected in maize (Zea mays) in Tanzania. Arch Virol 164:1711-1715

98. Reuter G, Boros A, Pál J, Kapusinszky B, Delwart E, Pankovics P (2016) Detection and genome analysis of a novel (dima)rhabdovirus (Riverside virus) from Ochlerotatus sp. mosquitoes in Central Europe. Infect Genet Evol 39:336-341

99. Ritter DG, Calisher CH, Muth DJ, Shope RE, Murphy FA, Whitfield SG (1978) New Minto virus: a new rhabdovirus from ticks in Alaska. Can J Microbiol 24:422-426

100. Rott ME, Kesanakurti P, Berwarth C, Rast H, Boyes I, Phelan J, Jelkmann W (2018) Discovery of negative-sense RNA viruses in trees infected with apple rubbery wood disease by next-generation sequencing. Plant Dis 102:1254-1263 
101. Sabin AB (1951) Experimental studies on Phlebotomus (pappataci, sandfly) fever during World War II. Arch Gesamte Virusforsch 4:367-410

102. Sather GE, Lewis AL, Jennings W, Bond JO, Hammon WM (1970) Sawgrass virus: a newly described arbovirus in Florida. Am J Trop Med Hyg 19:319-326

103. Scarpassa VM, Debat HJ, Alencar RB, Saraiva JF, Calvo E, Arcà B, Ribeiro JMC (2019) An insight into the sialotranscriptome and virome of Amazonian anophelines. BMC Genom 20:166

104. Shah KV, Work TH (1969) Bhanja virus: a new arbovirus from ticks Haemaphysalis intermedia Warburton and Nuttall, 1909, in Orissa, India. Indian J Med Res 57:793-798

105. Shahhosseini N, Lühken R, Jöst H, Jansen S, Börstler J, Rieger T, Krüger A, Yadouleton A, de Mendonça Campos R, CirneSantos CC, Ferreira DF, Garms R, Becker N, Tannich E, Cadar D, Schmidt-Chanasit J (2017) Detection and characterization of a novel rhabdovirus in Aedes cantans mosquitoes and evidence for a mosquito-associated new genus in the family Rhabdoviridae. Infect Genet Evol 55:260-268

106. Shi M, Lin XD, Tian JH, Chen LJ, Chen X, Li CX, Qin XC, Li J, Cao JP, Eden JS, Buchmann J, Wang W, Xu J, Holmes EC, Zhang YZ (2016) Redefining the invertebrate RNA virosphere. Nature 540:539-543

107. Shi M, Neville P, Nicholson J, Eden J-S, Imrie A, Holmes EC (2017) High-resolution metatranscriptomics reveals the ecological dynamics of mosquito-associated RNA viruses in western Australia. J Virol 91:e00680-17

108. Shi M, Lin X-D, Chen X, Tian J-H, Chen L-J, Li K, Wang W, Eden J-S, Shen J-J, Liu L, Holmes EC, Zhang Y-Z (2018) The evolutionary history of vertebrate RNA viruses. Nature 556:197-202

109. Siddell SG, Walker PJ, Lefkowitz EJ, Mushegian AR, Adams MJ, Dutilh BE, Gorbalenya AE, Bz Harrach, Harrison RL, Junglen S, Knowles NJ, Kropinski AM, Krupovic M, Kuhn JH, Nibert M, Rubino L, Sabanadzovic S, Sanfaçon H, Simmonds P, Varsani A, Zerbini FM, Davison AJ (2019) Additional changes to taxonomy ratified in a special vote by the International Committee on Taxonomy of Viruses (October 2018). Arch Virol 164:943-946

110. Spence L, Anderson CR, Aitken THG, Downs WG (1966) Aruac virus, a new agent isolated from Trinidadian mosquitoes. Am $\mathrm{J}$ Trop Med Hyg 15:231-234

111. St George TD, Doherty RL, Carley JG, Filippich C, Brescia A, Casals J, Kemp DH, Brothers N (1985) The isolation of arboviruses including a new flavivirus and a new bunyavirus from Ixodes (Ceratixodes) uriae (Ixodoidea: Ixodidae) collected at Macquarie Island, Australia, 1975-1979. Am J Trop Med Hyg 34:406-412

112. Straková $P$, Dufkova L, Širmarová J, Salát J, Bartonička T, Klempa B, Pfaff F, Höper D, Hoffmann B, Ulrich RG, Růžek D (2017) Novel hantavirus identified in European bat species Nyctalus noctula. Infect Genet Evol 48:127-130

113. Sun Q, Zhao Q, An X, Guo X, Zuo S, Zhang X, Pei G, Liu W, Cheng S, Wang Y, Shu P, Mi Z, Huang Y, Zhang Z, Tong Y, Zhou H, Zhang J (2017) Complete genome sequence of Menghai rhabdovirus, a novel mosquito-borne rhabdovirus from China. Arch Virol 162:1103-1106

114. Swei A, Russell BJ, Naccache SN, Kabre B, Veeraraghavan N, Pilgard MA, Johnson BJB, Chiu CY (2013) The genome sequence of lone star virus, a highly divergent bunyavirus found in the Amblyomma americanum tick. PLoS One 8:e62083

115. Tchouassi DP, Marklewitz M, Chepkorir E, Zirkel F, Agha SB, Tigoi CC, Koskei E, Drosten C, Borgemeister C, Torto B, Junglen S, Sang R (2019) Sand fly-associated phlebovirus with evidence of neutralizing antibodies in humans, Kenya. Emerg Infect Dis 25:681-690
116. Tesh RB, Chaniotis BN, Peralta PH, Johnson KM (1974) Ecology of viruses isolated from Panamanian phlebotomine sandflies. Am J Trop Med Hyg 23:258-269

117. Tesh RB (1975) Multiplication of Phlebotomus fever group arboviruses in mosquitos after intrathoracic inoculation. J Med Entomol 12:1-4

118. Tesh RB, Boshell J, Young DG, Morales A, De Carrasquilla CF, Corredor A, Modi GB, Travassos Da Rosa APA, McLean RG, De Rodriguez C, Gaitan MO (1989) Characterization of 5 new phleboviruses recently isolated from sand flies in tropical America. Am J Trop Med Hyg 40:529-533

119. Tokarz R, Sameroff S, Leon MS, Jain K, Lipkin WI (2014) Genome characterization of Long Island tick rhabdovirus, a new virus identified in Amblyomma americanum ticks. Virol J 11:26

120. Tokarz R, Williams SH, Sameroff S, Sanchez Leon M, Jain K, Lipkin WI (2014) Virome analysis of Amblyomma americanum, Dermacentor variabilis, and Ixodes scapularis ticks reveals novel highly divergent vertebrate and invertebrate viruses. J Virol 88:11480-11492

121. Trapp EE, Paes de Andrade AH, Shope RE (1965) Itaporanga, a newly reecognized arbovirus from Sao Paulo State, Brazil. Proc Soc Exp Biol Med 118:421-422

122. Travassos da Rosa APA, Tesh RB, Pinheiro FP, Travassos da Rosa JFS, Peterson NE (1983) Characterization of eight new phlebotomus fever serogroup arboviruses (Bunyaviridae: Phlebovirus) from the Amazon region of Brazil. Am J Trop Med Hyg 32:1164-1171

123. Vasilakis N, Tesh RB, Widen SG, Mirchandani D, Walker PJ (2019) Genomic characterisation of Cuiaba and Charleville viruses: arboviruses (family Rhabdoviridae, genus Sripuvirus) infecting reptiles and amphibians. Virus Genes 55:87-94

124. Velasco L, Arjona-Girona I, Cretazzo E, López-Herrera C (2019) Viromes in Xylariaceae fungi infecting avocado in Spain. Virology 532:11-21

125. Verani P, Ciufolini MG, Nicoletti L, Balducci M, Sabatinelli G, Coluzzi M, Paci P, Amaducci L (1982) Studi ecologici ed epidemiologici del virus Toscana, un arbovirus isolato da flebotomi. Ann Ist Super Sanita 18:397-9

126. Walker PJ, Firth C, Widen SG, Blasdell KR, Guzman H, Wood TG, Paradkar PN, Holmes EC, Tesh RB, Vasilakis N (2015) Evolution of genome size and complexity in the Rhabdoviridae. PLoS Pathog 11:e1004664

127. Walker PJ, Siddell SG, Lefkowitz EJ, Mushegian AR, Dempsey DM, Dutilh BE, Harrach B, Harrison RL, Hendrickson RC, Junglen S, Knowles NJ, Kropinski AM, Krupovic M, Kuhn JH, Nibert M, Rubino L, Sabanadzovic S, Simmonds P (2019) Changes to virus taxonomy and the International Code of Virus Classification and Nomenclature ratified by the International Committee on Taxonomy of Viruses (2019). Arch Virol 164:2417-2429

128. Walker PJ, Siddell SG, Lefkowitz EJ, Mushegian AR, Adriaenssens E, Dempsey DM, Dutilh BE, Harrach Bz, Harrison RL, Hendrickson RC, Junglen S, Knowles NJ, Kropinski AM, Krupovic M, Kuhn JH, Nibert M, Rubino L, Sabanadzovic S, Simmonds P, Varsani A, Zerbini FM, Davison AJ (2020) Changes to virus taxonomy and the Statutes ratified by the International Committee on Taxonomy of Viruses (2020). Arch Virol

129. Wang H, Liu Y, Liu W, Cao M, Wang X (2019) Sequence analysis and genomic organization of a novel chuvirus, Tàiyuán leafhopper virus. Arch Virol 164:617-620

130. Wang J, Selleck P, Yu M, Ha W, Rootes C, Gales R, Wise T, Crameri S, Chen H, Broz I, Hyatt A, Woods R, Meehan B, McCullough S, Wang L-F (2014) Novel phlebovirus with zoonotic potential isolated from ticks, Australia. Emerg Infect Dis 20:1040-1043 
131. Wang Y, Hua W, Wang J, Hannoufa A, Xu Z, Wang Z (2013) Deep sequencing of Lotus corniculatus L. reveals key enzymes and potential transcription factors related to the flavonoid biosynthesis pathway. Mol Genet Genom 288:131-139

132. Wanzeller ALM, Martins LC, Diniz Júnior JAP, de Almeida Medeiros DB, Cardoso JF, da Silva DEA, de Oliveira LF, de Vasconcelos JM, Nunes MRT, da S. G. Vianez Júnior JL, Vasconcelos PFC (2014) Xiburema virus, a hitherto undescribed virus within the family Rhabdoviridae isolated in the Brazilian Amazon Region. Genome Announc 2:e00454-14

133. Willie K, Stewart LR (2017) Complete genome sequence of a new maize-associated cytorhabdovirus. Genome Announc 5:e00591-17

134. Winter S, Koerbler M, Shahraeen N, Katul L, Lesemann D-E (2003) Characterization of a new tospovirus species infecting tomato in Iran. J Plant Dis Prot 110:74

135. Winton JR, Batts WN, Powers RL, Purcell MK (2019) Complete genome sequences of the index isolates of two genotypes of Pacific salmon paramyxovirus. Microbiol Resour Announc 8:e01521-18

136. Wolf YI, Kazlauskas D, Iranzo J, Lucía-Sanz A, Kuhn JH, Krupovic M, Dolja VV, Koonin EV (2018) Origins and evolution of the global RNA virome. MBio 9:e02329-18

137. Woyessa AB, Omballa V, Wang D, Lambert A, Waiboci L, Ayele W, Ahmed A, Abera NA, Cao S, Ochieng M, Montgomery JM, Jima D, Fields B (2014) An outbreak of acute febrile illness caused by sandfly fever Sicilian virus in the Afar Region of Ethiopia, 2011. Am J Trop Med Hyg 91:1250-1253

138. Wu L-P, Yang T, Liu H-W, Postman J, Li R (2018) Molecular characterization of a novel rhabdovirus infecting blackcurrant identified by high-throughput sequencing. Arch Virol 163:1363-1366

139. Wu Z, Du J, Lu L, Yang L, Dong J, Sun L, Zhu Y, Liu Q, Jin Q (2018) Detection of Hantaviruses and Arenaviruzses [sic] in three-toed jerboas from the Inner Mongolia Autonomous Region, China. Emerg Microbes Infect 7:35

140. Wu Z, Lu L, Du J, Yang L, Ren X, Liu B, Jiang J, Yang J, Dong J, Sun L, Zhu Y, Li Y, Zheng D, Zhang C, Su H, Zheng Y, Zhou H, Zhu G, Li H, Chmura A, Yang F, Daszak P, Wang J, Liu Q, Jin Q (2018) Comparative analysis of rodent and small mammal viromes to better understand the wildlife origin of emerging infectious diseases. Microbiome 6:178

141. Xu C, Sun X, Taylor A, Jiao C, Xu Y, Cai X, Wang X, Ge C, Pan G, Wang Q, Fei Z, Wang Q (2017) Diversity, distribution, and evolution of tomato viruses in China uncovered by small RNA sequencing. J Virol 91:e0173-17

142. Xu FL, Liu DY, Nunes MRT, Da Rosa A, Tesh RB, Xiao SY (2007) Antigenic and genetic relationships among Rift Valley fever virus and other selected members of the genus Phlebovirus (Bunyaviridae). Am J Trop Med Hyg 76:1194-1200

143. Xu Y, Lou S-G, Li XL, Zheng Y-X, Wang W-C, Liu Y-T (2013) The complete S RNA and M RNA nucleotide sequences of a hippeastrum chlorotic ringspot virus (HCRV) isolate from
Hymenocallis littoralis (Jacq.) Salisb in China. Arch Virol 158:2597-2601

144. Yadav PD, Nyayanit DA, Shete AM, Jain S, Majumdar TP, Chaubal GY, Shil P, Kore PM, Mourya DT (2019) Complete genome sequencing of Kaisodi virus isolated from ticks in India belonging to Phlebovirus genus, family Phenuiviridae. Ticks Tick Borne Dis 10:23-33

145. Yang X-L, Zhang Y-Z, Jiang R-D, Guo H, Zhang W, Li B, Wang N, Wang L, Waruhiu C, Zhou J-H, Li S-Y, Daszak P, Wang L-F, Shi Z-L (2017) Genetically diverse filoviruses in Rousettus and Eonycteris spp. bats, China, 2009 and 2015. Emerg Infect Dis 23:482-486

146. Yang X-L, Tan CW, Anderson DE, Jiang R-D, Li B, Zhang W, Zhu Y, Lim XF, Zhou P, Liu X-L, Guan W, Zhang L, Li S-Y, Zhang Y-Z, Wang L-F, Shi Z-L (2019) Characterization of a filovirus (Měnglà virus) from Rousettus bats in China. Nat Microbiol 4:390-395

147. Yang X, Huang J, Liu C, Chen B, Zhang T, Zhou G (2016) Rice stripe mosaic virus, a novel cytorhabdovirus infecting rice via leafhopper transmission. Front Microbiol 7:2140

148. Zhao G, Krishnamurthy S, Cai Z, Popov VL, Travassos da Rosa AP, Guzman H, Cao S, Virgin HW, Tesh RB, Wang D (2013) Identification of novel viruses using VirusHunter - an automated data analysis pipeline. PLoS One 8:e78470

149. Бутенко АМ, Громашевский ВЛ, Львов ДК, Попов ВФ (1979) Вирус Кисемайо-представитель антигенной группы Бханджа. Вопр Вирусол:661-5

150. Львов ДК, Альховский СВ, Щелканов МЮ, Щетинин АМ, Дерябин ПГ, Аристова ВА, Гительман АК, Самохвалов ЕИ, Ботиков АГ (2014) Генетическая характеристика вирусов Сахалин (SAKV - Sakhalin virus), Парамушир (PMRV - Paramushir virus) (Bunyaviridae, Nairovirus, группа Сахалин) и Рукутама (RUKV - Rukutama virus) (Bunyaviridae, Phlebovirus, группа Укуниеми), изолированных от облигатных паразитов колониальных морских птиц - клещей Ixodes (Ceratixodes) uriae, White 1852 и I. signatus Birulya, 1895 в бассейнах Охотского и Берингова морей. Вопр Вирусол 59:11-17

151. Львов ДК, Альховский СВ, Щелканов МЮ, Щетинин АМ, Дерябин ПГ, Гительман АК, Самохвалов ЕИ, Ботиков АГ (2014) Генетическая характеристика штаммов вируса Залив Терпения (ZTV - Zaliv Terpeniya virus) (Bunyaviridae, Phlebovirus, антигенный комплекс Укуниеми), изолированного в высоких широтах Северной Евразии из облигатных эктопаразитов чистиковых птиц (Alcidae Leach, 1820)клещей Ixodes (Ceratixodes) uriae White, 1852 и от комаров Culex modestus Ficalbi, 1889 в субтропиках Закавказья. Вопр Вирусол 59:12-18

Publisher's Note Springer Nature remains neutral with regard to jurisdictional claims in published maps and institutional affiliations.

\section{Affiliations}

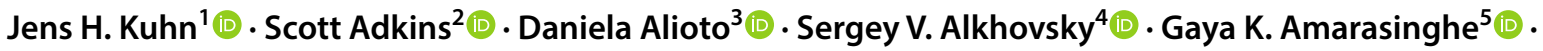
Simon J. Anthony ${ }^{6,7} \cdot$ Tatjana Avšič-Županc $^{8}$ (1) María A. Ayllón ${ }^{9,10}$ - Justin Bahl ${ }^{11}$ (1) .

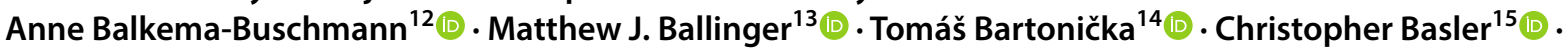

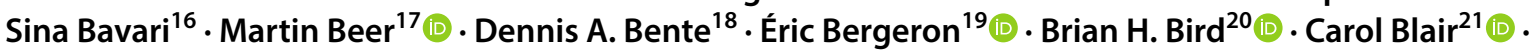
Kim R. Blasdell ${ }^{22}$ - Steven B. Bradfute ${ }^{23}$ (D) Rachel Breyta ${ }^{24}$. Thomas Briese ${ }^{25}$ (D) Paul A. Brown ${ }^{26}$ (D)

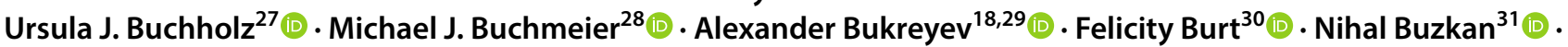




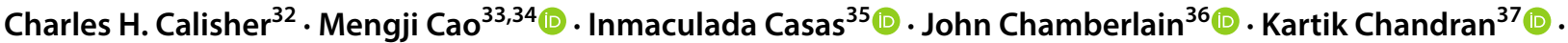
Rémi N. Charrel ${ }^{38}$ - Biao Chen ${ }^{39} \cdot$ Michela Chiumenti $^{40}$ - Il-Ryong Choi ${ }^{41} \cdot$ J. Christopher S. Clegg ${ }^{42}$. Ian Crozier $^{43}{ }^{(1)}$. John V. da Graça ${ }^{44}$. Elena Dal Bó ${ }^{45}$. Alberto M. R. Dávila ${ }^{46}$. Juan Carlos de la Torre ${ }^{47}$ (1) Xavier de Lamballerie ${ }^{38} \cdot$ Rik L. de Swart $^{48}$ (D) Patrick L. Di Bello ${ }^{49}$ (i) . Nicholas Di Paola ${ }^{50}$ (1) Francesco Di Serio ${ }^{40}$ (1) Ralf G. Dietzgen ${ }^{51}$ (1) Michele Digiaro ${ }^{52} \cdot$ Valerian V. Dolja 53 (1) Olga Dolnik ${ }^{54}$ - Michael A. Drebot ${ }^{55}$.

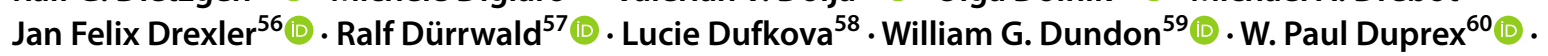
John M. Dye ${ }^{50}$ (1) Andrew J. Easton ${ }^{61}$ (1) Hideki Ebihara ${ }^{62}$ (D) Toufic Elbeaino ${ }^{63} \cdot$ Koray Ergünay $^{64}$ (D) Jorlan Fernandes ${ }^{195}$ (D) Anthony R. Fooks ${ }^{65}$ - Pierre B. H. Formenty ${ }^{66}$ (D) Leonie F. Forth ${ }^{17}$ (1) . Ron A. M. Fouchier ${ }^{48}$ (1) . Juliana Freitas-Astúa ${ }^{67}$ (1) Selma Gago-Zachert ${ }^{68,69}{ }^{(1)} \cdot$ George Fú Gão $^{70}$. María Laura García ${ }^{71}$. Adolfo García-Sastre ${ }^{72}$ - Aura R. Garrison ${ }^{50}$ - Aiah Gbakima ${ }^{73}$ - Tracey Goldstein $^{74}$ (1) . Jean-Paul J. Gonzalez $z^{75,76}$ (i) Anthony Griffiths ${ }^{77}$ (i) - Martin H. Groschup ${ }^{12}$ (D) Stephan Günther ${ }^{78}$ (i) .

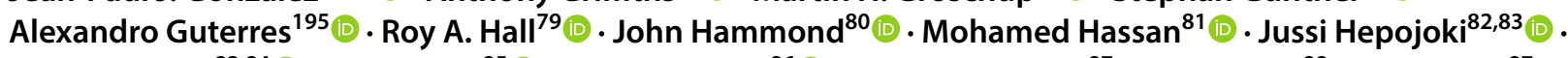

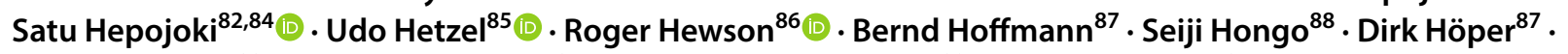

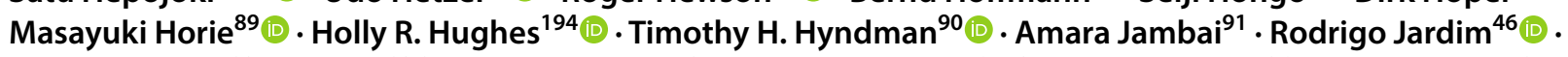
Dàohóng Jiāng ${ }^{92}$ (D) Qi Jin ${ }^{93,94}$. Gilda B. Jonson ${ }^{95}$. Sandra Junglen ${ }^{56,118}$. Serpil Karadağ ${ }^{96} \cdot$ Karen E. Keller $^{97}$.

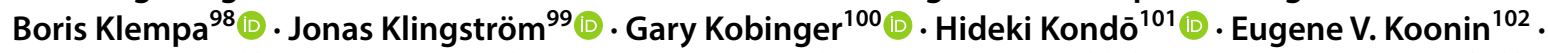

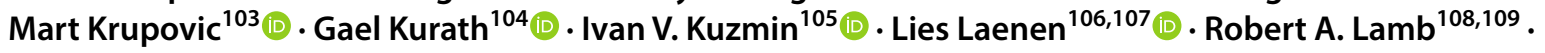

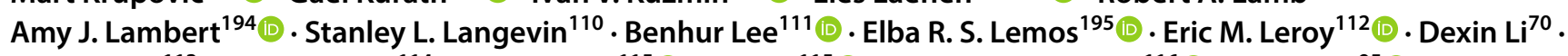

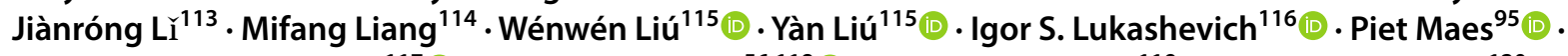
William Marciel de Souza ${ }^{117}$ (1) Marco Marklewitz ${ }^{56,118}$ (1) . Sergio H. Marshall ${ }^{119}$. Giovanni P. Martelli ${ }^{120}$. Robert R. Martin ${ }^{121}$ (1) . Shin-Yi L. Marzano ${ }^{122}$. Sébastien Massart ${ }^{123} \cdot$ John W. McCauley ${ }^{124}$ (1) Nicole Mielke-Ehret ${ }^{125}$. Angelantonio Minafra ${ }^{40}$ (1) Maria Minutolo ${ }^{3}$ (D) Ali Mirazimi ${ }^{126} \cdot$ Hans-Peter Mühlbach $^{125}$.

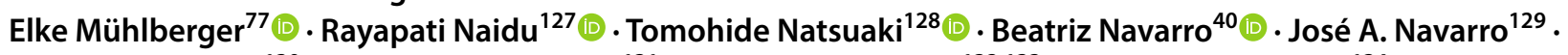

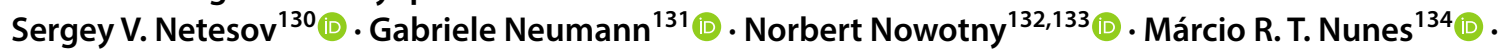
Are Nylund $^{135}$ - Arnfinn L. Økland ${ }^{135} \cdot$ Renata C. Oliveira ${ }^{195}$ (C) . Gustavo Palacios ${ }^{50}$ (i) $\cdot$ Vicente Pallas $^{136}$ (1) Bernadett Pályi $i^{137}$ - Anna Papa ${ }^{138} \cdot$ Colin R. Parrish $^{139}$ - Alex Pauvolid-Corrêa ${ }^{140}$ - Janusz T. Pawęska ${ }^{141}$ (1)

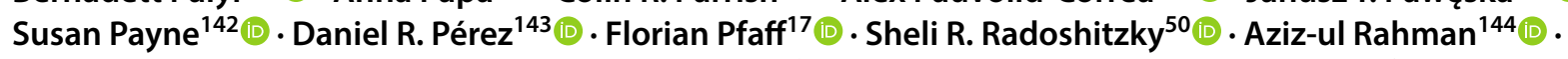
Pedro L. Ramos-González ${ }^{145}$ (I) Renato O. Resende ${ }^{146}$ (D) Carina A. Reyes ${ }^{147} \cdot$ Bertus K. Rima $^{148}$ (D) Víctor Romanowski ${ }^{149}$. Gabriel Robles Luna ${ }^{147}$. Paul Rota ${ }^{150}$. Dennis Rubbenstroth ${ }^{17}$. Jonathan A. Runstadler ${ }^{151}$ (1) . Daniel Ruzek ${ }^{58,152}$. Sead Sabanadzovic ${ }^{153}$ - Jiř́ Salát ${ }^{58,152}$ - Amadou Alpha Sall ${ }^{154} \cdot$ Maria S. Salvato ${ }^{155}$ (1). Kamil Sarpkaya ${ }^{156} \cdot$ Takahide Sasaya $^{157}$ (1) Martin Schwemmle ${ }^{158}$ (1) Muhammad Z. Shabbir ${ }^{144}(\mathbb{D}$.

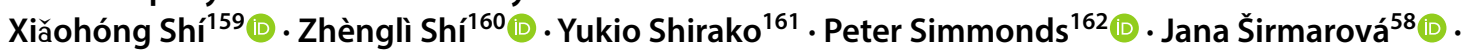
Manuela Sironi ${ }^{163}$ (1) Sophie Smither ${ }^{164} \cdot$ Teemu Smura $^{82}$. Jin-Won Song ${ }^{165} \cdot$ Kirsten M. Spann $^{166}$ (D)

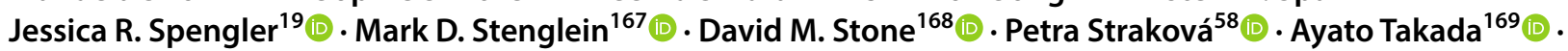
Robert B. Tesh ${ }^{29} \cdot$ Natalie J. Thornburg ${ }^{170} \cdot$ Keizō Tomonaga ${ }^{171}$ (1) Noël Tordo ${ }^{172,173}$ ( J Jonathan S. Towner ${ }^{19}$ (1)

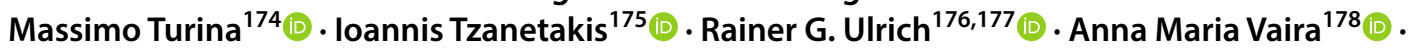

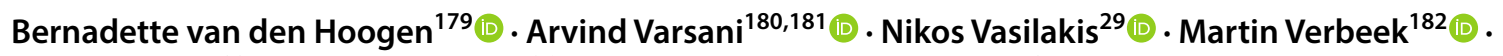

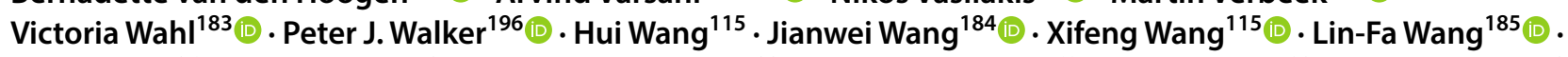

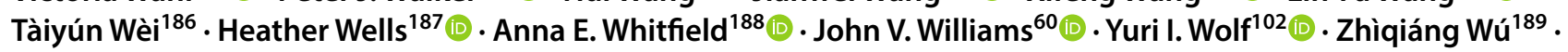

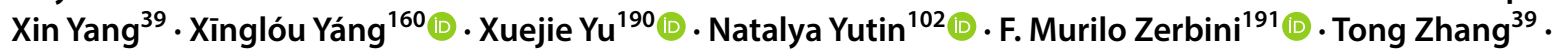
Yong-Zhen Zhang ${ }^{192,193} \cdot$ Guohui Zhou ${ }^{39} \cdot$ Xueping Zhou ${ }^{115}$

Jens H. Kuhn

kuhnjens@mail.nih.gov

Scott Adkins

scott.adkins@ars.usda.gov

Daniela Alioto

alioto@unina.it

Sergey V. Alkhovsky

salkh@ya.ru

Gaya K. Amarasinghe

GAmarasinghe@path.wustl.edu
Simon J. Anthony sja2127@cumc.columbia.edu

Tatjana Avšič-Županc

Tatjana.Avsic@mf.uni-lj.si

María A. Ayllón

mariaangeles.ayllon@upm.es

Justin Bahl

JUSTIN.BAHL@uga.edu

Anne Balkema-Buschmann anne.buschmann@fli.de 
Matthew J. Ballinger

ballinger@biology.msstate.edu

Tomáš Bartonička

bartonic@sci.muni.cz

Christopher Basler

cbasler@gsu.edu

Sina Bavari

sina.bavari@comcast.net

Martin Beer

Martin.Beer@fli.de

Dennis A. Bente

dabente@UTMB.EDU

Éric Bergeron

exj8@CDC.GOV

Brian H. Bird

bhbird@ucdavis.edu

Carol Blair

Carol.Blair@ColoState.EDU

Kim R. Blasdell

kim.blasdell@csiro.au

Steven B. Bradfute

sbradfute@salud.unm.edu

Rachel Breyta

rbjmax@uw.edu

Thomas Briese

tb2047@cumc.columbia.edu

Paul A. Brown

paul.brown@anses.fr

Ursula J. Buchholz

ubuchholz@niaid.nih.gov

Michael J. Buchmeier

m.buchmeier@uci.edu

Alexander Bukreyev

alexander.bukreyev@utmb.edu

Felicity Burt

burtfj@ufs.ac.za

Nihal Buzkan

nbuzkan@ksu.edu.tr

Charles H. Calisher

calisher@cybersafe.net

Mengji Cao

caomengji@cric.cn

Inmaculada Casas

icasas@isciii.es

John Chamberlain

john.chamberlain@phe.gov.uk

Kartik Chandran

kartik.chandran@einstein.yu.edu

Rémi N. Charrel

remi.charrel@univ-amu.fr

Biao Chen

chenbiaobcb@163.com
Michela Chiumenti

michela.chiumenti@ipsp.cnr.it

Il-Ryong Choi

ichoi51@hotmail.com

J. Christopher S. Clegg

cleggjcs@yahoo.fr

Ian Crozier

ian.crozier@nih.gov

John V. da Graça

john.dagraca@tamuk.edu

Elena Dal Bó

elenadalbocastanion@gmail.com

Alberto M. R. Dávila

alberto.davila@ fiocruz.br

Juan Carlos de la Torre

juanct@ scripps.edu

Xavier de Lamballerie

xavier.de-lamballerie@univ-amu.fr

Rik L. de Swart

r.deswart@erasmusmc.nl

Patrick L. Di Bello

patrick.dibello@oregonstate.edu

Nicholas Di Paola

nicholas.dipaola.ctr@mail.mil

Francesco Di Serio

francesco.diserio@ipsp.cnr.it

Ralf G. Dietzgen

r.dietzgen@uq.edu.au

Michele Digiaro

digiaro@iamb.it

Valerian V. Dolja

doljav@oregonstate.edu

Olga Dolnik

Dolnik@staff.uni-marburg.de

Michael A. Drebot

mike.drebot@canada.ca

Jan Felix Drexler

felix.drexler@charite.de

Ralf Dürrwald

duerrwaldr@rki.de

Lucie Dufkova

dufkoval@vri.cz

William G. Dundon

W.Dundon@iaea.org

W. Paul Duprex

pduprex@pitt.edu

John M. Dye

john.m.dye1.civ@mail.mil

Andrew J. Easton

A.J.Easton@warwick.ac.uk

Hideki Ebihara

Ebihara.Hideki@mayo.edu 
Toufic Elbeaino

elbeaino@iamb.it

Koray Ergünay

ekoray@hacettepe.edu.tr

Jorlan Fernandes

jorlan@ioc.fiocruz.br

Anthony R. Fooks

Tony.Fooks@apha.gov.uk

Pierre B. H. Formenty

formentyp@who.int

Leonie F. Forth

leonie.forth@fli.de

Ron A. M. Fouchier

r.fouchier@erasmusmc.nl

Juliana Freitas-Astúa

juliana.astua@embrapa.br

Selma Gago-Zachert

sgago@ipb-halle.de

George Fú Gāo

gaof@im.ac.cn

María Laura García

garcia_m@biol.unlp.edu.ar

Adolfo García-Sastre

Adolfo.Garcia-Sastre@mssm.edu

Aura R. Garrison

aura.r.garrison.civ@mail.mil

Aiah Gbakima

gbakimaaa2009@gmail.com

Tracey Goldstein

tgoldstein@ucdavis.edu

Jean-Paul J. Gonzalez

Jean.Paul.Gonzalez@georgetown.edu;

jpgonzalez2808@gmail.com

Anthony Griffiths

ahgriff@bu.edu

Martin H. Groschup

Martin.Groschup@fli.de

Stephan Günther

guenther@bni.uni-hamburg.de

Alexandro Guterres

guterres@ioc.fiocruz.br

Roy A. Hall

roy.hall@uq.edu.au

John Hammond

John.Hammond@ars.usda.gov

Mohamed Hassan

maa22@fayoum.edu.eg

Jussi Hepojoki

jussi.hepojoki@helsinki.fi; jussi.hepojoki@uzh.ch

Satu Hepojoki

satu.hepojoki@mobidiag.com

Udo Hetzel

udo.hetzel@uzh.ch
Roger Hewson

roger.hewson@phe.gov.uk

Bernd Hoffmann

Bernd.Hoffmann@fli.de

Seiji Hongo

shongou@med.id.yamagata-u.ac.jp

Dirk Höper

Dirk.Hoeper@fli.de

Masayuki Horie

horie.masayuki.3m@kyoto-u.ac.jp

Holly R. Hughes

1tr8@cdc.gov

Timothy H. Hyndman

T.Hyndman@murdoch.edu.au

Amara Jambai

amarajambai@yahoo.com

Rodrigo Jardim

jardim@ioc.fiocruz.br

Dàohóng Jiāng

daohongjiang@mail.hzau.edu.cn

Qi Jin

zdsys@vip.sina.com

Gilda B. Jonson

G.Jonson@irri.org; jonson_gilda@yahoo.com

Sandra Junglen

sandra.junglen@charite.de

Serpil Karadağ

skaradag27@hotmail.com

Karen E. Keller

kellerk@oregonstate.edu

Boris Klempa

boris.klempa@savba.sk

Jonas Klingström

jonas.klingstrom@ki.se

Gary Kobinger

Gary.Kobinger@crchudequebec.ulaval.ca

Hideki Kondō

hkondo@ rib.okayama-u.ac.jp

Eugene V. Koonin

koonin@ncbi.nlm.nih.gov

Mart Krupovic

mart.krupovic@pasteur.fr

Gael Kurath

gkurath@usgs.gov

Ivan V. Kuzmin

ivkuzmin@yandex.ru

Lies Laenen

lies.laenen@uzleuven.be

Robert A. Lamb

ralamb@northwestern.edu

Amy J. Lambert

ahk7@CDC.GOV 
Stanley L. Langevin

slangevi@uw.edu

Benhur Lee

benhur.lee@mssm.edu

Elba R. S. Lemos

elemos@ioc.fiocruz.br

Eric M. Leroy

eric.leroy@ird.fr

Dexin Li

lidx@ chinacdc.cn

Jiànróng Lǐ

li.926@ osu.edu

Mifang Liang

mifangl@hotmail.com

Wénwén Liú

liuwenwen98@163.com

Yàn Liú

liuyan06@caas.cn

Igor S. Lukashevich

isluka01@ louisville.edu

Piet Maes

piet.maes@kuleuven.be

William Marciel de Souza

wmarciel@hotmail.com

Marco Marklewitz

marco.marklewitz@charite.de

Sergio H. Marshall

sergio.marshall@pucv.cl

Giovanni P. Martelli

martelli@agr.uniba.it

Robert R. Martin

robert.martin@oregonstate.edu

Shin-Yi L. Marzano

shinyi.marzano@usda.gov

Sébastien Massart

sebastien.massart@uliege.be

John W. McCauley

john.mccauley@crick.ac.uk

Nicole Mielke-Ehret

nicole_mielke@hotmail.com

Angelantonio Minafra

angelantonio.minafra@ipsp.cnr.it

Maria Minutolo

minutolm@unina.it

Ali Mirazimi

Ali.Mirazimi@ki.se

Hans-Peter Mühlbach

hpmuehlbach@gmx.net;

muehlbach@botanik.uni-hamburg.de

Elke Mühlberger

muehlber@bu.edu

Rayapati Naidu

naidu.rayapati@wsu.edu
Tomohide Natsuaki

natsuaki@cc.utsunomiya-u.ac.jp

Beatriz Navarro

beatriz.navarro@ipsp.cnr.it

José A. Navarro

janavarr@ibmcp.upv.es

Sergey V. Netesov

netesov.s@nsu.ru

Gabriele Neumann

gabriele.neumann@wisc.edu

Norbert Nowotny

Norbert.Nowotny@vetmeduni.ac.at

Márcio R. T. Nunes

marcionunesbrasil@yahoo.com.br

Are Nylund

are.nylund@uib.no

Arnfinn L. Økland

arnfinn.okland@uib.no

Renata C. Oliveira

reoliveira@ioc.fiocruz.br

Gustavo Palacios

gustavo.f.palacios.civ@mail.mil

Vicente Pallas

vpallas@ibmcp.upv.es

Bernadett Pályi

palyi.bernadett@oki.antsz.hu

Anna Papa

annap.med@gmail.com

Colin R. Parrish

crp3@cornell.edu

Alex Pauvolid-Corrêa

pauvolid@gmail.com

Janusz T. Pawęska

januszp@nicd.ac.za

Susan Payne

SPayne@cvm.tamu.edu

Daniel R. Pérez

dperez1@uga.edu

Florian Pfaff

florian.pfaff@fli.de

Sheli R. Radoshitzky

sheli.r.radoshitzky.ctr@mail.mil

Aziz-ul Rahman

drazizangel@gmail.com

Pedro L. Ramos-González

plrg1970@gmail.com

Renato O. Resende

rresende@unb.br

Carina A. Reyes

carirey2306@gmail.com

Bertus K. Rima

b.rima@qub.ac.uk 
Víctor Romanowski

victor@biol.unlp.edu.ar

Gabriel Robles Luna

garobles@gmail.com

Paul Rota

par1@CDC.GOV

Dennis Rubbenstroth

Dennis.Rubbenstroth@fli.de

Jonathan A. Runstadler

Jonathan.Runstadler@tufts.edu

Daniel Ruzek

ruzekd@paru.cas.cz

Sead Sabanadzovic

SSabanadzovic@entomology.msstate.edu

Jiří Salát

salat@vri.cz

Amadou Alpha Sall

Amadou.SALL@pasteur.sn

Maria S. Salvato

MSalvato@ihv.umaryland.edu

Kamil Sarpkaya

kamilsarpkaya@karabuk.edu.tr

Takahide Sasaya

tsasaya@affrc.go.jp

Martin Schwemmle

martin.schwemmle@uniklinik-freiburg.de

Muhammad Z. Shabbir

shabbirmz@uvas.edu.pk

Xiăohóng Shí

Xiaohong.Shi@glasgow.ac.uk

Zhènglì Shí

zlshi@wh.iov.cn

Yukio Shirako

yshirako@mac.com

Peter Simmonds

peter.simmonds@ndm.ox.ac.uk

Jana Širmarová

jsirmarova@gmail.com

Manuela Sironi

manuela.sironi@BP.LNF.it

Sophie Smither

SJSMITHER@mail.dstl.gov.uk

Teemu Smura

Teemu.Smura@helsinki.fi

Jin-Won Song

jwsong@korea.ac.kr

Kirsten M. Spann

Kirsten.Spann@qut.edu.au

Jessica R. Spengler

JSpengler@cdc.gov

Mark D. Stenglein

Mark.Stenglein@ColoState.edu
David M. Stone

david.stone@cefas.co.uk

Petra Straková

strakova.p@centrum.cz

Ayato Takada

atakada@czc.hokudai.ac.jp

Robert B. Tesh

rbtesh22@gmail.com

Natalie J. Thornburg

nax3@cdc.gov

Keizō Tomonaga

tomonaga.keizo.5r@kyoto-u.ac.jp;

tomonaga@infront.kyoto-u.ac.jp

Noël Tordo

ntordo@pasteur.fr

Jonathan S. Towner

jit8@CDC.GOV

Massimo Turina

massimo.turina@ipsp.cnr.it

Ioannis Tzanetakis

itzaneta@uark.edu

Rainer G. Ulrich

Rainer.Ulrich@fli.de

Anna Maria Vaira

annamaria.vaira@ipsp.cnr.it

Bernadette van den Hoogen

b.vandenhoogen@erasmusmc.nl

Arvind Varsani

arvind.varsani@asu.edu

Nikos Vasilakis

nivasila@utmb.edu

Martin Verbeek

martin.verbeek@wur.nl

Victoria Wahl

victoria.wahl@st.dhs.gov

Peter J. Walker

peter.walker@uq.edu.au

Hui Wang

whsmilewh@163.com

Jianwei Wang

wangjw28@163.com

Xifeng Wang

xfwang@ippcaas.cn

Lin-Fa Wang

linfa.wang@duke-nus.edu.sg

Tàiyún Wèi

weitaiyun@fafu.edu.cn

Heather Wells

hlw2124@cumc.columbia.edu

Anna E. Whitfield

awhitfi@ncsu.edu

John V. Williams

jvw@chp.edu 
Yuri I. Wolf

wolf@ncbi.nlm.nih.gov

Zhìqiáng Wú

wuzq2009@ipbcams.ac.cn

Xin Yang

xy2012204717@163.com

Xīnglóu Yáng

yangxl@wh.iov.cn

Xuejie Yu

yuxuejie@whu.edu.cn

Natalya Yutin

yutin@ncbi.nlm.nih.gov

F. Murilo Zerbini

zerbini@ufv.br

Tong Zhang

zhangtong@scau.edu.cn

Yong-Zhen Zhang

zhangyongzhen@icdc.cn

Guohui Zhou

ghzhou@scau.edu.cn

Xueping Zhou

zzhou@zju.edu.cn

1 Integrated Research Facility at Fort Detrick, National Institute of Allergy and Infectious Diseases, National Institutes of Health, Fort Detrick, Frederick, MD, USA

2 United States Department of Agriculture, Agricultural Research Service, US Horticultural Research Laboratory, Fort Pierce, FL, USA

3 Dipartimento di Agraria, Università degli Studi di Napoli Federico II, Portici, Italy

4 D.I. Ivanovsky Institute of Virology of N.F. Gamaleya National Center on Epidemiology and Microbiology of Ministry of Health of Russian Federation, Moscow, Russia

5 Department of Pathology and Immunology, Washington University School of Medicine, St. Louis, MO, USA

6 Mailman School of Public Health, Columbia University, New York, NY, USA

7 EcoHealth Alliance, New York, NY, USA

8 Ljubljana Faculty of Medicine, University of Ljubljana, Ljubljana, Slovenia

9 Centro de Biotecnología y Genómica de Plantas, Universidad Politécnica de Madrid-Instituto Nacional de Investigación y Tecnología Agraria y Alimentaria, Campus de Montegancedo, Pozuelo de Alarcón, Madrid, Spain

10 Departamento de Biotecnología-Biología Vegetal, Escuela Técnica Superior de Ingeniería Agronómica, Alimentaria y de Biosistemas, Universidad Politécnica de Madrid, Madrid, Spain

11 Department of Infectious Diseases, Department of Epidemiology and Biostatistics, Institute of Bioinformatics, Center for Ecology of Infectious Diseases, University of Georgia, Athens, GA, USA
12 Friedrich-Loeffler-Institut, Federal Research Institute for Animal Health, Institute of Novel and Emerging Infectious Diseases, Greifswald-Insel Riems, Germany

13 Department of Biological Sciences, Mississippi State University, Mississippi State, MS, USA

14 Department of Botany and Zoology, Masaryk University, Brno, Czech Republic

15 Center for Microbial Pathogenesis, Institute for Biomedical Sciences, Georgia State University, Atlanta, GA, USA

16 Edge BioInnovation Consulting and Mgt, Frederick, MD, USA

17 Institute of Diagnostic Virology, Friedrich-Loeffler-Institut, Greifswald-Insel Riems, Germany

18 Galveston National Laboratory, The University of Texas, Medical Branch at Galveston, Galveston, TX, USA

19 Viral Special Pathogens Branch, Division of High-Consequence Pathogens and Pathology, Centers for Disease Control and Prevention, Atlanta, GA, USA

20 School of Veterinary Medicine, One Health Institute, University of California, Davis, CA, USA

21 Department of Microbiology, Immunology and Pathology, Colorado State University, Fort Collins, CO, USA

22 Commonwealth Scientific and Industrial Research Organisation (CSIRO), Australian Centre for Disease Preparedness, Geelong, VIC, Australia

23 University of New Mexico Health Sciences Center, Albuquerque, NM, USA

24 US Geological Survey, Western Fisheries Research Center, Seattle, WA, USA

25 Department of Epidemiology, Mailman School of Public Health, Center for Infection and Immunity, Columbia University, New York, NY, USA

26 Laboratory of Ploufragan-Plouzané-Niort, French Agency for Food, Environmental and Occupational Heath Safety ANSES, Ploufragan, France

27 RNA Viruses Section, Laboratory of Infectious Diseases, National Institute of Allergy and Infectious Diseases, National Institutes of Health, Bethesda, MD, USA

28 Department of Molecular Biology and Biochemistry, University of California, Irvine, CA, USA

29 Department of Pathology, The University of Texas Medical Branch, Galveston, TX, USA

30 Division of Virology, National Health Laboratory Service, University of the Free State, Bloemfontein, Republic of South Africa

31 Department of Plant Protection, Faculty of Agriculture, Kahramanmaras Sütçü Imam University, Avsar Campus, 46060 Kahramanmaras, Turkey

32 Colorado State University, Fort Collins, CO, USA

33 National Citrus Engineering Research Center, Citrus Research Institute, Southwest University, Chongqing 400712, China

34 Academy of Agricultural Sciences, Southwest University, Chongqing 400715, China 
35 Respiratory Virus and Influenza Unit, National Microbiology Center, Instituto de Salud Carlos III, Madrid, Spain

36 Virology and Pathogenesis Group, National Infection Service, Public Health England, Porton Down, UK

37 Department of Microbiology and Immunology, Albert Einstein College of Medicine, Bronx, NY, USA

38 Unité des Virus Emergents (Aix-Marseille Univ-IRD 190-Inserm 1207-IHU Méditerranée Infection), Marseille, France

39 Guangdong Province Key Laboratory of Microbial Signals and Disease Control, College of Agriculture, South China Agricultural University, Guangdong, China

40 Istituto per la Protezione Sostenibile delle Piante-Consiglio Nazionale delle ricerche (Institute for Sustainable Plant Protection-National Research Council), Bari, Italy

41 Plant Breeding Genetics and Biotechnology Division, International Rice Research Institute, Los Baños, Philippines

42 Les Mandinaux, Le Grand Madieu, France

43 Clinical Monitoring Research Program Directorate, Frederick National Laboratory for Cancer Research, Frederick, MD, USA

44 Texas A\&M University-Kingsville Citrus Center, Weslaco, TX, USA

45 CIDEFI. Facultad de Ciencias Agrarias y Forestales, Universidad de La Plata, La Plata, Argentina

46 Laboratório de Biologia Computacional e Sistemas, Fundação Oswaldo Cruz-Fiocruz, Instituto Oswaldo Cruz, Rio de Janeiro, RJ, Brasil

47 Department of Immunology and Microbiology IMM-6, The Scripps Research Institute, La Jolla, CA, USA

48 Department Viroscience, Erasmus MC University Medical Centre Rotterdam, Rotterdam, The Netherlands

49 Department of Botany and Plant Pathology, Oregon State University, Corvallis, OR 97331, USA

50 United States Army Medical Research Institute of Infectious Diseases, Fort Detrick, Frederick, MD, USA

51 Queensland Alliance for Agriculture and Food Innovation, The University of Queensland, St. Lucia, QLD, Australia

52 CIHEAM, Istituto Agronomico Mediterraneo di Bari, Valenzano, Italy

53 Department of Botany and Plant Pathology, Oregon State University, Corvallis, OR, USA

54 Institute of Virology, Philipps University Marburg, Marburg, Germany

55 Zoonotic Diseases and Special Pathogens, National Microbiology Laboratory, Public Health Agency of Canada, Winnipeg, MB, Canada

56 Institute of Virology, Charité-Universitätsmedizin Berlin, corporate member of Free University Berlin, Humboldt-University Berlin, and Berlin Institute of Health, Berlin, Germany

57 Robert Koch Institut, Berlin, Germany

58 Veterinary Research Institute, Brno, Czech Republic
59 Animal Production and Health Laboratory, Joint FAO/IAEA Division of Nuclear Techniques in Food and Agriculture, Department of Nuclear Sciences and Applications, International Atomic Energy Agency, Vienna, Austria

60 School of Medicine, University of Pittsburgh, Pittsburgh, PA, USA

61 School of Life Sciences, University of Warwick, Coventry, UK

62 Department of Molecular Medicine, Mayo Clinic, Rochester, MN, USA

63 Istituto Agronomico Mediterraneo di Bari, Valenzano, Italy

64 Virology Unit, Department of Medical Microbiology, Faculty of Medicine, Hacettepe University, Ankara, Turkey

65 Animal and Plant Health Agency, Weybridge, Surrey, UK

66 World Health Organization, Geneva, Switzerland

67 Embrapa Cassava and Fruits, Cruz das Almas, Bahia, Brazil

68 Institute of Biochemistry and Biotechnology, Martin Luther University Halle-Wittenberg, Halle/Saale, Germany

69 Department of Molecular Signal Processing, Leibniz Institute of Plant Biochemistry, Halle/Saale, Germany

70 National Institute for Viral Disease Control and Prevention, Chinese Center for Disease Control and Prevention, Beijing, China

71 Instituto de Biotecnología y Biología Molecular, Facultad de Ciencias Exactas, CONICET UNLP, La Plata, Argentina

72 Icahn School of Medicine at Mount Sinai, New York, NY, USA

73 Metabiota, Inc. Sierra Leone, Freetown, Sierra Leone

74 One Health Institute, Karen C. Drayer Wildlife Health Center, School of Veterinary Medicine, University of California, Davis, CA, USA

75 Department of Microbiology and Immunology, Division of Biomedical Graduate Research Organization, School of Medicine, Georgetown University, Washington, DC 20057, USA

76 Centaurus Biotechnologies, CTP, Manassas, VA, USA

77 Department of Microbiology and National Emerging Infectious Diseases Laboratories, Boston University School of Medicine, Boston, MA, USA

78 Department of Virology, Bernhard-Nocht Institute for Tropical Medicine, WHO Collaborating Centre for Arboviruses and Hemorrhagic Fever Reference and Research, Hamburg, Germany

79 Australian Infectious Diseases Research Centre, School of Chemistry and Molecular Biosciences, The University of Queensland, Brisbane, Australia

80 United States Department of Agriculture, Agricultural Research Service, USNA, Floral and Nursery Plants Research Unit, Beltsville, MD, USA

81 Department of Agricultural Botany, Faculty of Agriculture, Fayoum University, Fayoum, Egypt

82 Department of Virology, University of Helsinki, Medicum, Helsinki, Finland 
83 Vetsuisse Faculty, Institute of Veterinary Pathology, University of Zurich, Zurich, Switzerland

84 Mobidiag Ltd, Espoo, Finland

85 Institute of Veterinary Pathology, University of Zuerich, Zurich, Switzerland

86 Public Health England, Porton Down, Salisbury, Wiltshire, UK

87 Friedrich-Loeffler-Institut, Greifswald-Insel Riems, Germany

88 Department of Infectious Diseases, Faculty of Medicine, Yamagata University, Yamagata, Japan

89 Hakubi Center for Advanced Research, Kyoto University, Kyoto, Japan

90 School of Veterinary Medicine, Murdoch University, Murdoch, WA, Australia

91 Ministry of Health and Sanitation, Freetown, Sierra Leone

92 State Key Laboratory of Agricultural Microbiology, Huazhong Agricultural University, Wuhan, Hubei, China

93 Ministry of Health Key Laboratory of Systems Biology of Pathogens, Institute of Pathogen Biology, Chinese Academy of Medical Sciences and Peking Union Medical College, Beijing, China

94 Collaborative Innovation Center for Diagnosis and Treatment of Infectious Diseases, Hangzhou, China

95 Department of Agricultural Biotechnology, Center for Fungal Pathogenesis, College of Agriculture and Life Sciences, Seoul National University, Seoul, South Korea

96 Republic Of Turkey Ministry Of Agriculture And Forestry, Pistachio Research Institute, Gaziantep, Turkey

97 United States Department of Agriculture, Agricultural Research Service, Horticulture Crops Research Unit, Corvallis, OR, USA

98 Institute of Virology, Biomedical Research Center, Slovak Academy of Sciences, Bratislava, Slovakia

99 Department of Medicine Huddinge, Center for Infectious Medicine, Karolinska Institutet, Karolinska University Hospital, Stockholm, Sweden

100 Department of Microbiology, Immunology and Infectious Diseases, Université Laval, Quebec City, Canada

101 Institute of Plant Science and Resources, Okayama University, Kurashiki, Japan

102 National Center for Biotechnology Information, National Library of Medicine, National Institutes of Health, Bethesda, MD, USA

103 Archaeal Virology Unit, Institut Pasteur, Paris, France

104 US Geological Survey Western Fisheries Research Center, Seattle, WA, USA

105 US Department of Agriculture, Animal and Plant Health Inspection, National Veterinary Services Laboratories, Diagnostic Virology Laboratory, Ames, USA

106 Zoonotic Infectious Diseases Unit, KU Leuven, Rega Institute, Leuven, Belgium

107 Department of Laboratory Medicine, University Hospitals Leuven, Leuven, Belgium
108 Department of Molecular Biosciences, Northwestern University, Evanston, IL, USA

109 Howard Hughes Medical Institute, Northwestern University, Evanston, IL, USA

110 Department of Microbiology, University of Washington, Washington, USA

111 Department of Microbiology, Icahn School of Medicine at Mount Sinai, New York, NY, USA

112 MIVEGEC (IRD-CNRS-Montpellier university) Unit, French National Research Institute for Sustainable Development (IRD), Montpellier, France

113 Department of Veterinary Biosciences, College of Veterinary Medicine, The Ohio State University, Columbus, OH, USA

114 Key Laboratory for Medical Virology, NHFPC, National Institute for Viral Disease Control and Prevention, Beijing, China

115 State Key Laboratory for Biology of Plant Diseases and Insect Pests, Institute of Plant Protection, Chinese Academy of Agricultural Sciences, Beijing, China

116 Department of Pharmacology and Toxicology, School of Medicine, The Center for Predictive Medicine for Biodefense and Emerging Infectious Diseases, University of Louisville, Louisville, KY, USA

117 Virology Research Center, University of São Paulo, Ribeirão Preto, Brazil

118 German Center for Infection Research (DZIF), Berlin, Germany

119 Pontificia Universidad Católica de Valparaíso, Campus Curauma, Valparaíso, Chile

120 Department of Plant, Soil and Food Sciences, University "Aldo Moro", Bari, Italy

121 United States Department of Agriculture, Horticultural Crops Research Unit, Corvallis, OR, USA

122 Department of Biology and Microbiology, Department of Plant Sciences, South Dakota State University, Brookings, $\mathrm{SD}$, USA

123 Gembloux Agro-Bio Tech, TERRA, Plant Pathology Laboratory, Liège University, Liège, Belgium

124 Worldwide Influenza Centre, Francis Crick Institute, London, UK

125 Biocentre Klein Flottbek, University of Hamburg, Hamburg, Germany

126 Folkhalsomyndigheten, Stockholm, Sweden

127 Department of Plant Pathology, Irrigated Agricultural Research and Extension Center, Washington State University, Prosser, WA, USA

128 School of Agriculture, Utsunomiya University, Utsunomiya, Tochigi, Japan

129 Instituto de Biología Molecular y Celular de Plantas, Universitat Politècnica de València-Consejo Superior de Investigaciones Científicas, Valencia, Spain

130 Novosibirsk State University, Novosibirsk, Novosibirsk Oblast, Russia 
131 Department of Pathobiological Sciences, Influenza Research Institute, University of Wisconsin-Madison, Madison, USA

132 Institute of Virology, University of Veterinary Medicine Vienna, Vienna, Austria

133 College of Medicine, Mohammed Bin Rashid University of Medicine and Health Sciences, Dubai, United Arab Emirates

134 Evandro Chagas Institute, Ministry of Health, Pará, Brazil

135 Fish Disease Research Group, Department of Biological Sciences, University of Bergen, Bergen, Norway

136 Instituto de Biología Molecular y Celular de Plantas (IBMCP), Consejo Superior de Investigaciones Cientificas-Universidad Politécnica de Valencia, Valencia, Spain

137 National Biosafety Laboratory, National Public Health Center, Budapest, Hungary

138 National Reference Centre for Arboviruses and Haemorrhagic Fever Viruses, Department of Microbiology, Medical School, Aristotle University of Thessaloniki, Thessaloníki, Greece

139 College of Veterinary Medicine, Baker Institute for Animal Health, Cornell University, Ithaca, NY, USA

140 Department of Veterinary Integrated Biosciences and Department of Entomology, Texas A\&M University, College Station, USA

141 Center for Emerging Zoonotic and Parasitic Diseases, National Institute for Communicable Diseases of the National Health Laboratory Service, Sandringham-Johannesburg, Gauteng, South Africa

142 Department of Veterinary Pathobiology, College of Veterinary Medicine and Biomedical Sciences, Texas A\&M University, College Station, TX, USA

143 Department of Population Health, College of Veterinary Medicine, University of Georgia, Athens, GA, USA

144 Institute of Microbiology, University of Veterinary and Animal Sciences, Lahore, Pakistan

145 Laboratório de Biologia Molecular Aplicada, Instituto Biológico, São Paulo, SP, Brazil

146 Departamento de Biologia Celular, Universidade de Brasília, Brasília, Brazil

147 Instituto de Biotecnología y Biología Molecular, CCT-La Plata, CONICET-UNLP, La Plata, Buenos Aires, Argentina

148 Centre for Experimental Medicine, School of Medicine, Dentistry and Biomedical Sciences, The Queen's University of Belfast, Belfast, Northern Ireland, UK

149 Instituto de Biotecnología y Biología Molecular, Centro Cientifico Technológico-La Plata, Consejo Nacional de Investigaciones Científico Tecnológico-Universidad Nacional de La Plata, La Plata, Argentina

150 National Center for Immunization and Respiratory Diseases, Centers for Disease Control and Prevention, Atlanta, GA, USA

151 Department of Infectious Disease and Global Health, Tufts University Cummings School of Veterinary Medicine, 200 Westboro Road, North Grafton, MA 01536, USA
152 Institute of Parasitology, Biology Centre of the Czech Academy of Sciences, Branisovska 31, 37005 Ceske Budejovice, Czech Republic

153 Department of Biochemistry, Molecular Biology, Entomology and Plant Pathology, Mississippi State University, Mississippi State, MS, USA

154 Institut Pasteur de Dakar, Dakar, Senegal

155 Institute of Human Virology, University of Maryland School of Medicine, Baltimore, MD, USA

156 Department of Forestry Engineering, Faculty of Forestry, Karabuk University (UNIKA), Karabük, Turkey

157 Western Region Agricultural Research Center, National Agriculture and Food Research Organization, Fukuyama, Japan

158 Faculty of Medicine, University Medical Center-University Freiburg, Freiburg, Germany

159 MRC-University of Glasgow Centre for Virus Research, Glasgow, Scotland, UK

160 CAS Key Laboratory of Special Pathogens, Wuhan Institute of Virology, Center for Biosafety Mega-Science, Chinese Academy of Sciences, Wuhan, Hubei, People's Republic of China

161 Asian Center for Bioresources and Environmental Sciences, University of Tokyo, Tokyo, Japan

162 Nuffield Department of Medicine, University of Oxford, Oxford, UK

163 Bioinformatics Unit, Scientific Institute IRCCS "E. Medea”, Bosisio Parini, Italy

164 CBR Division, Dstl, Porton Down, Salisbury, Wiltshire, UK

165 Department of Microbiology, College of Medicine, Korea University, Seoul, Republic of Korea

166 School of Biomedical Sciences, Faculty of Health, Queensland University of Technology, Brisbane, QLD, Australia

167 Department of Microbiology, Immunology, and Pathology, College of Veterinary Medicine and Biomedical Sciences, Colorado State University, Fort Collins, CO, USA

168 Centre for Environment, Fisheries and Aquaculture Science, Weymouth, Dorset, UK

169 Division of Global Epidemiology, Research Center for Zoonosis Control, Hokkaido University, Sapporo, Japan

170 Centers for Disease Control and Prevention, Atlanta, GA, USA

171 Institute for Frontier Life and Medical Sciences (inFront), Kyoto University, Kyoto, Japan

172 Institut Pasteur, Unité des Stratégies Antivirales, WHO Collaborative Centre for Viral Haemorrhagic Fevers and Arboviruses, OIE Reference Laboratory for RVFV and $\mathrm{CCHFV}$, Paris, France

173 Institut Pasteur de Guinée, Conakry, Guinea

174 Institute for Sustainable Plant Protection, National Research Council of Italy (CNR), Strada delle Cacce 73, 10135 Turin, Italy 
175 Division of Agriculture, Department of Entomology and Plant Pathology, University of Arkansas System, Fayetteville, AR 72701, USA

176 Friedrich-Loeffler-Institut, Federal Research Institute for Animal Health, Institute of Novel and Emerging Infectious Diseases, Südufer 10, 17493 Greifswald-Insel Riems, Germany

177 German Center of Infection Research (DZIF), Partner site Hamburg-Lübeck-Borstel-Insel Riems, Greifswald-Insel Riems, Germany

178 Institute for Sustainable Plant Protection, National Research Council of Italy (IPSP-CNR), 73 Strada delle Cacce, 10135 Turin, Italy

179 Department of Viroscience, Erasmus MC University Medical Centre Rotterdam, Rotterdam, The Netherlands

180 The Biodesign Center for Fundamental and Applied Microbiomics, Center for Evolution and Medicine School of Life Sciences, Arizona State University, Tempe, AZ, USA

181 Structural Biology Research Unit, Department of Clinical Laboratory Sciences, University of Cape Town, Observatory, Cape Town, South Africa

182 Wageningen University and Research, Biointeractions and Plant Health, Wageningen, The Netherlands

183 National Biodefense Analysis and Countermeasures Center, Fort Detrick, Frederick, MD, USA

184 NHC Key Laboratory of Systems Biology of Pathogens and Christophe Mérieux Laboratory, IPB-Fondation Mérieux, Institute of Pathogen Biology, Chinese Academy of Medical Sciences and Peking Union Medical College, Beijing, China
185 Programme in Emerging Infectious Diseases, Duke-NUS Medical School, Singapore, Singapore

186 Fujian Province Key Laboratory of Plant Virology, Institute of Plant Virology, Fujian Agriculture and Forestry University, Fuzhou, Fujian, China

187 Mailman School of Public Health, Center for Infection and Immunity, Columbia University, New York, USA

188 Department of Entomology and Plant Pathology, North Carolina State University, Raleigh, NC, USA

189 MOH Key Laboratory of Systems Biology of Pathogens, IPB, CAMS, Beijing, China

190 Wuhan University School of Health Sciences, Wuhan, China

191 Departamento de Fitopatologia, Instituto de Biotecnologia Aplicada à Agropecuária, Universidade Federal de Viçosa, Viçosa, Minas Gerais, Brazil

192 National Institute for Communicable Disease Control and Prevention, Chinese Center for Disease Control and Prevention, Changping, Beijing, China

193 Shanghai Public Health Clinical Center, Institutes of Biomedical Sciences, Fudan University, Shanghai, China

194 Centers for Disease Control and Prevention, Fort Collins, CO, USA

195 Laboratório de Hantaviroses e Rickettsioses, Fundação Oswaldo Cruz-Fiocruz, Instituto Oswaldo Cruz, Rio de Janeiro, RJ, Brasil

196 School of Biological Sciences, University of Queensland, St. Lucia, Queensland, Australia 